\title{
A Slice of Tourism: The Nature, Dimensions and Geographies of International Golf Tourism in New Zealand
}

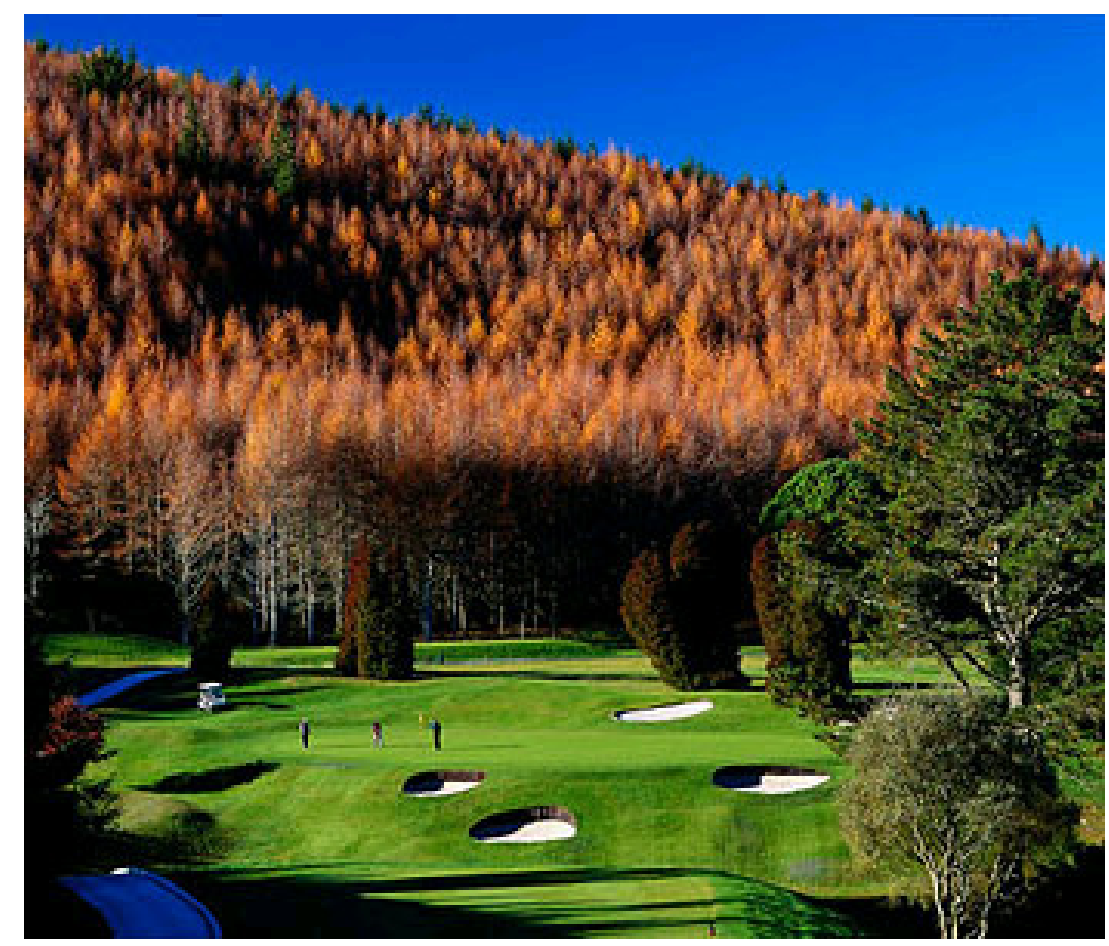

\section{By Chris Gazley}

\section{Victoria University 2010}

A thesis submitted to the Institute of Geography, Victoria University of Wellington in fulfilment of the requirement for the degree of Master of Science 


\section{Acknowledgements}

I would like to thank everyone who helped me during my long year of writing this thesis. Thank you to my supervisor, Richard Willis for his guidance and many hours spent on this; to Sophia for also helping with ideas, proof reading and for motivation when I needed it; to Conway for helping with all things to do with computers and finally to all research participants for their thoughts. This thesis would not have been possible without them. 


\section{Abstract}

Tourism is one of the largest and fastest growing industries in the world and for New Zealand it is the most important industry along with dairy. Of the 2.5 million tourists who visit New Zealand each year, it is estimated that around 65,000 (3\%) of visitors will play at least one game of golf while in the country. New Zealand's profile as a golfing destination has increased in recent years and now boasts a number of the worlds top ranked courses. This, along with the low cost of playing golf in New Zealand has made it an attractive golfing destination.

This thesis aims to gain a greater insight into the nature and dimensions of the golf tourism industry in New Zealand and of those who visit. This research was conducted through a range of interviews with 19 stakeholders in the golf tourism industry, as well as a golfer's questionnaire to which 44 international visitors responded.

This research has found that international golf tourism plays an important role for many golf courses throughout New Zealand and the number of visitors is on the rise. These visitors tend to be wealthier and spend more money than the average tourist during their stay and so the benefits of increasing this market go beyond what is spent on the golf course alone. However, New Zealand must first overcome a number of barriers if international golf tourism is to reach its full potential. The key barriers to growth are New Zealand's geographic isolation, the large distances between New Zealand's top courses, competition from other golfing destinations and a lack of marketing to increase the awareness of New Zealand as a golfing destination. 


\section{Table of Contents}

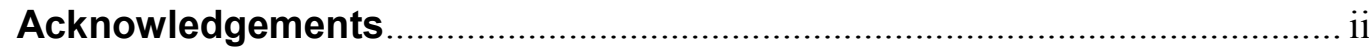

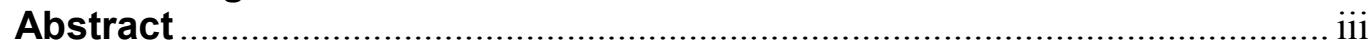

List of Tables ........................................................................................... vii

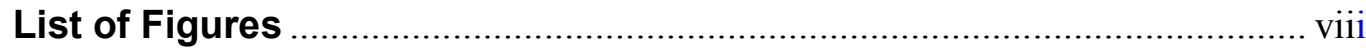

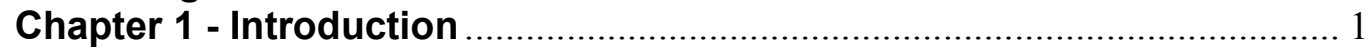

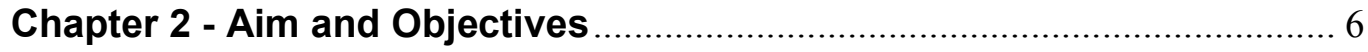

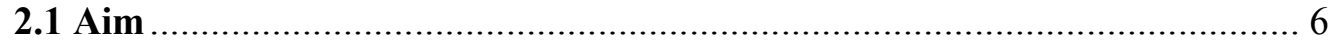

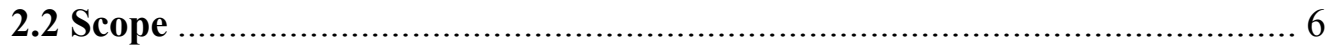

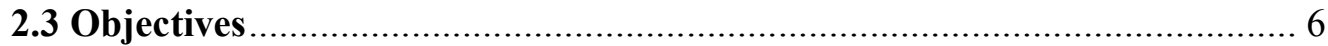

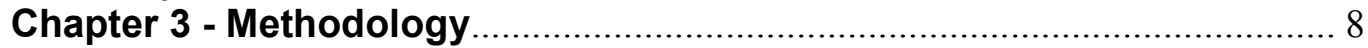

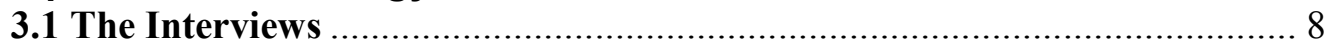

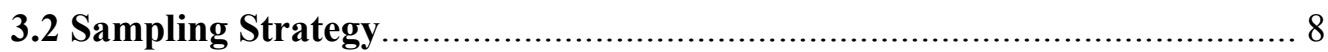

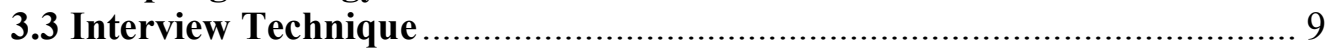

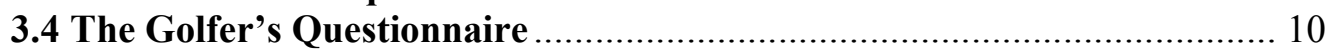

Chapter 4 - Literature Review............................................................. 13

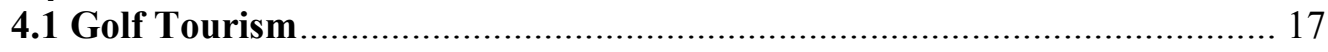

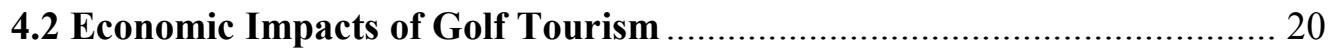

4.2.1 The Economic Impacts of Golf in the United States........................... 20

4.2.2 Economic Impact in Europe, The Middle East and Africa ................... 21

4.3 Golf Tourist's Behaviour, Motivations and Demographics ..................... 27

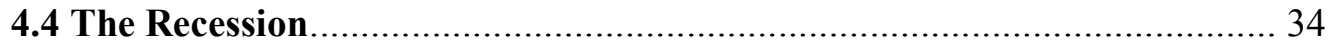

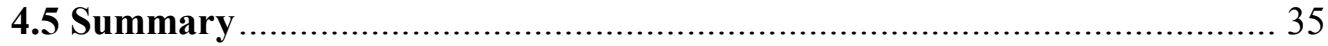

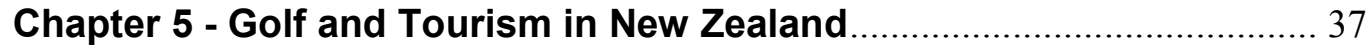

5.1 The Cost of Playing Golf in New Zealand.............................................. 40

5.2 Golf Tourism Data for New Zealand .................................................. 42

5.3 The Economic Benefits of Golf Tourism in New Zealand ........................ 46

Chapter 6 - Golf Tourism in New Zealand: Interview and Questionnaire

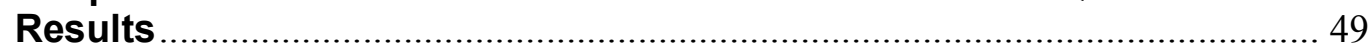

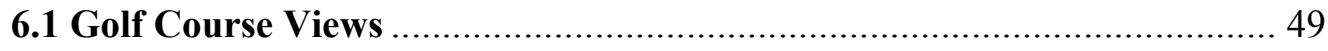

6.2 Golf Course Marketing........................................................................ 51

6.3 Golf Tourism Cluster........................................................................ 52

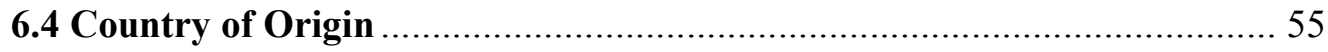

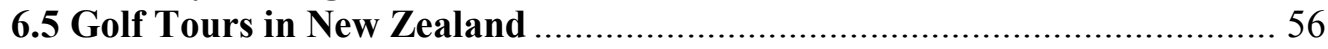

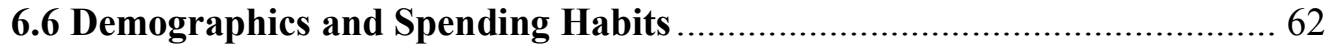

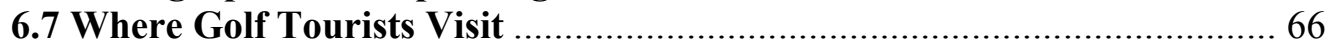

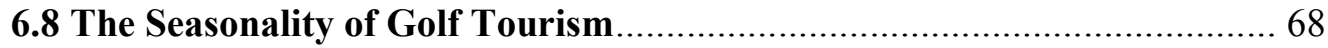

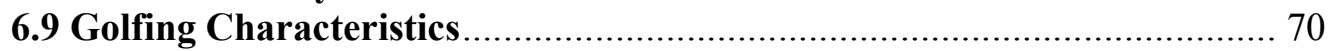

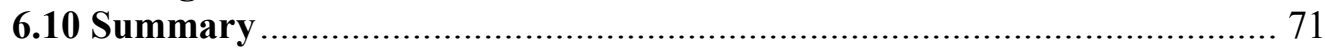

Chapter 7 - Golf and the Recession in New Zealand.............................. 72

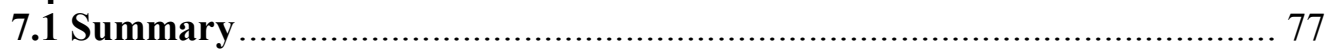

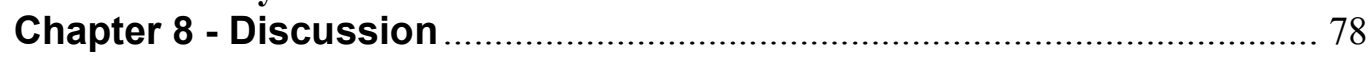

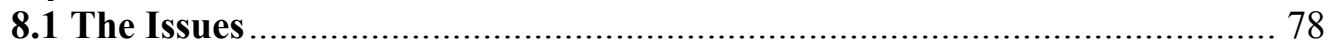

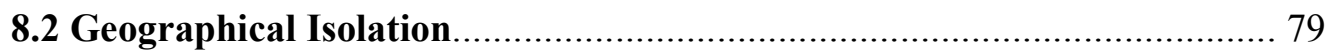

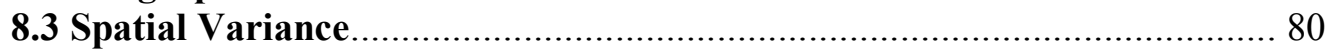

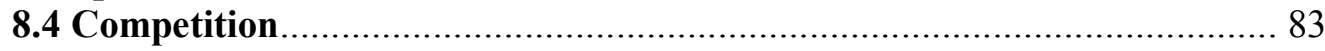




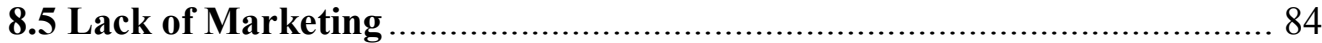

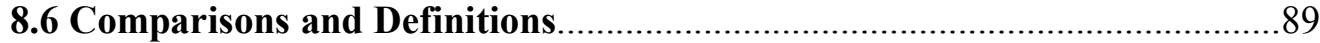

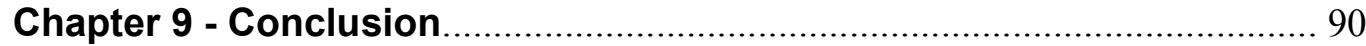

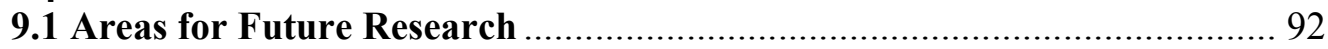




\section{List of Tables}

Table 1: Top 10 countries in terms of golf courses per capita - 2007

Table 2: Economic Impact of Golf Related Travel 21

Table 3: Total Number of Golf Courses in Europe, 1990 and 2008

Table 4: Origin of golf tourists and general tourists visiting Australia 28

Table 5: Weather Comparisons for Golfing Destinations throughout the World 31

Table 6: Core Golfers in the US - Spending Effects of the Recession 35

Table 7: Average Cost of Playing at New Zealand Golf Courses 41

Table 8: Total spending by international golfers in New Zealand 46

Table 9: Baggage Allowance when flying into New Zealand 50

Table 10: Visitor Numbers and Origin to Courses in New Zealand 50

Table 11: The Percentage of Golf Tourists vs Total Tourist Arrivals 56

Table 12: Positive and Negative Attributes of Golf Tourist's time in New Zealand 60 


\section{List of Figures}

Figure 1: International Arrivals to New Zealand (1950s - 1990s) 1

Figure 2: Sports Visitors to New Zealand per year: 2003-2008 average 2

Figure 3: An overview of the structure of this thesis 5

$\begin{array}{ll}\text { Figure 4: Total International Arrivals 1950-2008 } & 13\end{array}$

Figure 5: The Tourism System 15

Figure 6: The Small World of Golf Tourism Literature 17

$\begin{array}{ll}\text { Figure 7: Golf Tourist Continuum } & 19\end{array}$

Figure 8: Monte-Rei Golf and Country Club in Portugal - A Jack Nicklaus Design 24

Figure 9: The $18^{\text {th }}$ Hole at St Andrews, the world's oldest surviving golf club 25

Figure 10: Origins of Golf Visitors to Victoria, Australia 28

Figure 11: Factors influencing Travel to a Golfing Destination 29

Figure 12: Temperature and Rainfall in Golfing Destinations 31

Figure 13: Sunshine Hours in Golfing Destinations 31

Figure 14: Spending of Golf Tourists in the EMA Region 33

Figure 15: New Zealand's Yearly Sports Participation Rates 37

Figure 16: Millbrook Resort, Queenstown 38

Figure 17: Origin of Golf Tourists to New Zealand 42

Figure 18: Gender of Golf Tourists to New Zealand 42

Figure 19: Age of Golf Tourists 43

Figure 20: Expenditure by Golf Tourists vs All Tourists (the average tourist) 44

Figure 21: Where International Visitors Played Golf 44

Figure 22: Cover page of the Pamphlet created by the Golf Tourism Cluster 52

Figure 23: Origin of Golf Visitors to New Zealand 54

$\begin{array}{ll}\text { Figure 24: Golf Tour Operators Websites } & 57\end{array}$

Figure 25: How the visitor first heard about travel to New Zealand 60

Figure 26: Those who would consider returning to New Zealand to play golf 61

Figure 27: Ages of Golf Tourists taking Tours 62

Figure 28: Huka Lodge - The luxury sought by many US golf tourists 63

Figure 29: Annual Earnings by Golf Tourists 65

Figure 30: Locations of popular courses visited by golf tourists 66

$\begin{array}{ll}\text { Figure 31: The Seasonality of Golf Tourism } & 67\end{array}$

Figure 32: The $7^{\text {th }}$ Hole at Terrace Downs overlooking Mt Hutt 68

Figure 33: Total number of rounds of golf per year by Golf Tourists 69

Figure 34: GDP growth rate in New Zealand since 2003 
Figure 35: The Effect of the Recession on those Interviewed

Figure 36: Future Expectations of Golf Tour Operators in the EMA region

Figure 37: A summary of the issues surrounding International Golf Tourism in New Zealand and how they are related 78

Figure 38: High Density Golfing Areas on the Sunshine Coast, Australia 


\section{Chapter 1}

\section{Introduction}

The trade and flow of goods and services has increased rapidly over the past century as technology has advanced. One major change seen from this is an increase in the flow of people between countries, both permanently (migration) and temporarily (tourism). Tourism is now one of the largest sectors of the world economy, accounting for $30 \%$ of total service exports worldwide (UNWTO, 2009).

For New Zealand, tourism is one of the most important industries in terms of Gross Domestic Product (GDP). Tourism is now in the country's top two export industries along with traditional primary exports such as dairy products. In 2006, tourism accounted for $\$ 7.9$ billion in direct revenue, accounting for $5.1 \%$ of GDP, while indirect revenue was estimated at a further $\$ 6.2$ billion to the New Zealand economy (Statistics New Zealand, 2008). Since 1950, tourist numbers have increased from less than 100,000 , to almost 2.5 million in 2009 .

Figure 1: International Arrivals to New Zealand (1950s - 1990s)

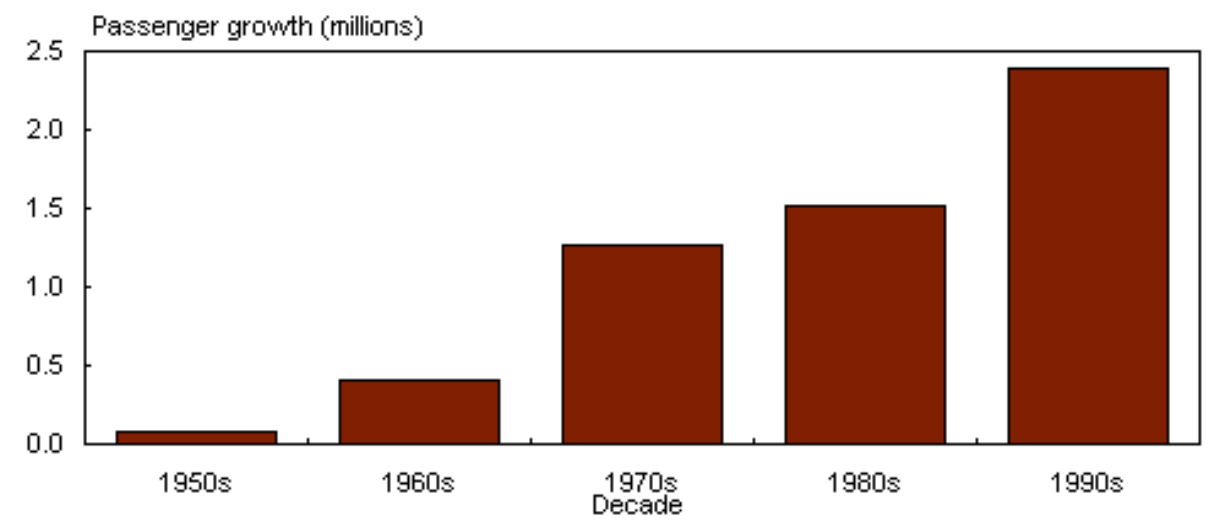

[Source: Statistics New Zealand, 2009] 
There are a number of reasons why people travel to New Zealand, with the most popular activity being general sightseeing (Ministry of Tourism, 2009). However, a proportion of tourists will either participate in or watch a sporting activity while in the country. For New Zealand, skiing/snow sports is the most popular sporting activity, followed by golf.

\section{Figure 2: Sports Visitors to New Zealand per year: 2003-2008 average}

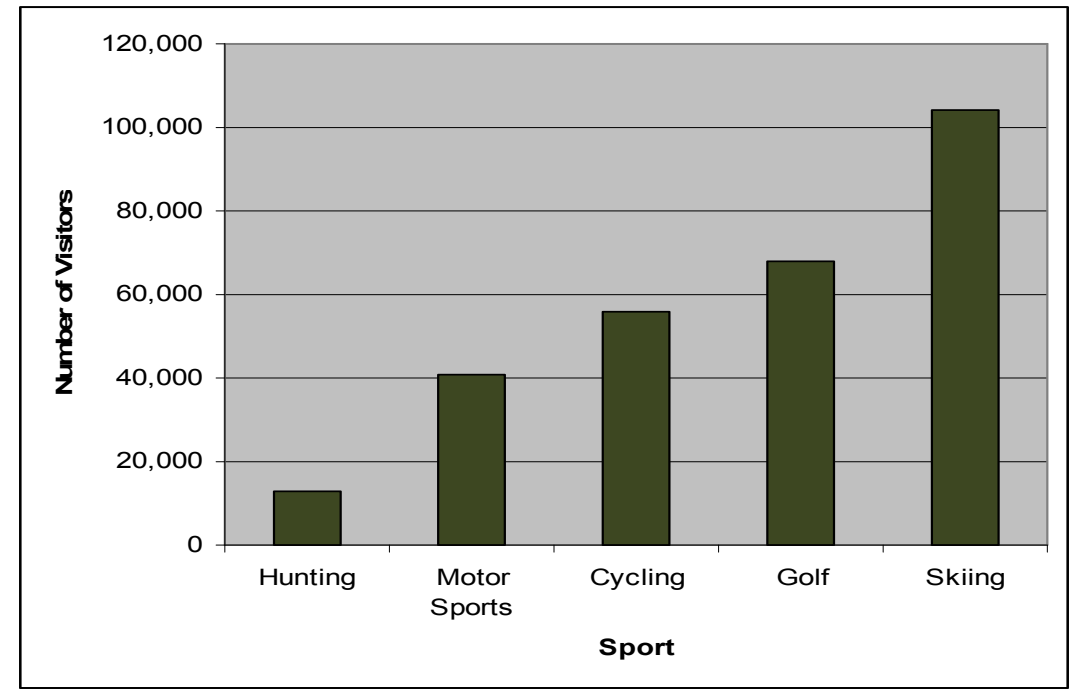

[Source: Ministry of Tourism, 2009]

While golf is the second most popular sporting activity for international visitors, it is also the most popular sport played by New Zealanders with up to 500,000 domestic residents participating each year (Sparc, 2009). On top of this, New Zealand has a high concentration of golf courses with more than 400 courses throughout the country. New Zealand is second to only Scotland in the number of golf courses per head of population (Golf Digest, 2007). The top 10 countries are shown in Table 1 below. 
Table 1: Top 10 countries in terms of golf courses per capita

\begin{tabular}{|l|l|}
\hline \multicolumn{1}{|c|}{ Country } & People per Golf Course \\
\hline Scotland & 9,379 \\
\hline New Zealand & 10,374 \\
\hline Australia & 11,063 \\
\hline Republic of Ireland & 14,127 \\
\hline Northern Ireland & 14,353 \\
\hline Canada & 15,480 \\
\hline Wales & 18,321 \\
\hline United States & 18,514 \\
\hline Sweden & 21,295 \\
\hline England & 27,725 \\
\hline
\end{tabular}

[Source: Golf Digest, 2007]

With a high number of courses and a low population, golf courses in New Zealand are relatively under utilised and therefore have the capacity for more than the 65,000 international visitors who currently play each year (Ministry of Tourism, 2009). While there has been some growth in the New Zealand golf tourism market over the past decade, more needs to be invested into marketing the New Zealand golfing experience in order for this growth to reach its full potential.

A review of the literature has shown that golfers are some of the largest spending tourists and on many occasions will spend more than twice the average tourist during their stay. The factors that are most important to these tourists are a country's climate, the quality of golf courses and the price. New Zealand has a temperate climate, has a number of golf courses ranked highly by independent sources and is a relatively inexpensive place to play golf. However, one of New Zealand's main barriers to growth in the golf tourism market is its geographical isolation from the rest of the world. 
Scotland is one country in which the government has taken a financial interest in researching the impact of golf tourism; however in New Zealand this is almost nonexistent. In 2002 the government put forward some funding for the creation of a 'Golf Tourism Cluster in New Zealand,' an industry wide approach to attract international golfers but little has been done since (Best of Golf New Zealand, 2009). International marketing of golf courses is primarily limited to golf courses themselves although expenditure for this remains low.

As far as the author is aware, research into the impacts of golf tourism in New Zealand is non-existent, both from a domestic and an international viewpoint. Research on golf in the country is limited to domestic players, such as the total number of players, membership numbers, gender and age distribution (NZGA, 2009). The typical golfer in New Zealand is a 60 year old male and this demographic is consistent with those found overseas. However, while demand for golf has been increasing throughout the world, New Zealand membership numbers have been declining in recent times, predominately due to an ageing population and time constraints (NZGA, 2009).

With New Zealand's population continuing to become older, a number of golf courses throughout New Zealand may struggle to survive. However, there are three possible ways to help counteract this problem.

1) Golf is generally viewed as a sport for older people and those under 25 years of age make up only a small proportion of total memberships. Therefore, there needs to be a way of enticing younger people into the game.

2) With over $50 \%$ of New Zealand's population being female, there also needs to be a way of attracting more of this demographic to play golf.

3) There are more than 60 million golfers throughout the world (Readman, 2003, 165). If more tourists can be bought over to New Zealand to play golf, it is not only good for the golf industry in New Zealand but for the tourism industry and the economy as a whole. 
This thesis will look into the third problem. In order to effectively market golf in New Zealand, more needs to be known about international golfers visiting New Zealand in order to employ the appropriate marketing practices. This thesis will therefore take an in-depth look into the international golf tourism market in New Zealand. Given the importance of tourism to New Zealand's economy, its high concentration of golf courses, high player numbers and lack of previous research, the author believes that it is an important time to investigate this topic.

The thesis will be structured into a number of chapters. Chapters two and three outline the main aim and objectives of the thesis as well as the methodology that was used to collate the required information. Chapters four and five will summarise research that has already been conducted on the topic. Chapters six and seven then show the results. Chapter eight will then discuss these results in more detail outlining a number of issues and ways for golf tourism to move forward. Chapter nine will then conclude the entire thesis and give a number of areas that would be beneficial to research in the future. This structure is summarised below in Figure 3.

\section{Figure 3: An overview of the structure of this thesis}

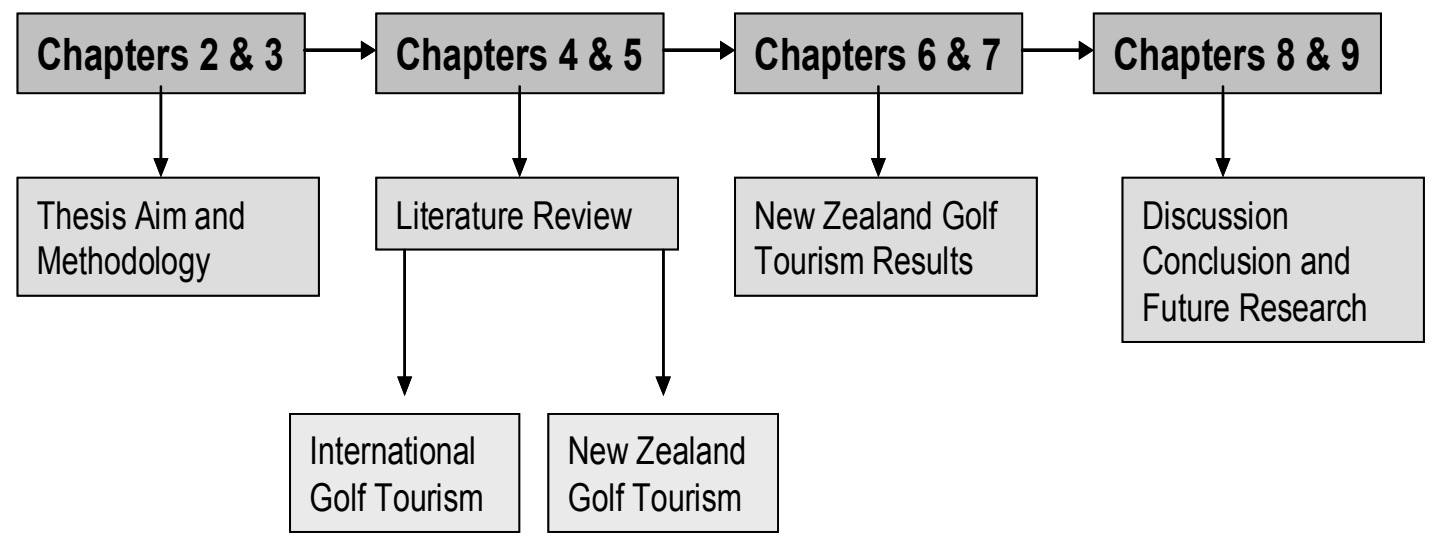




\section{Chapter 2}

\section{Aim and Objectives}

\subsection{Aim}

The overall aim of this thesis is to find out about the nature and dimensions of New Zealand's international golf tourism market. This includes determining the demographics of international golfers who visit, their travelling and spending habits as well as the importance of golf tourism to the New Zealand economy.

\subsection{Scope}

Golf tourism can be split into two groups; domestic golf tourism and international golf tourism. While domestic golf tourism is a large and important industry in itself, it is outside the scope of this thesis. In order to gain a more in-depth and thorough understanding of the research topic, only golfers from international destinations have been focused on, and within this, the main focus is on those who organise their travels using tour operators. Domestic golf tourism has been left for future research.

\subsection{Objectives}

In order to achieve the aims of this thesis, four specific objectives have been defined. These are listed below:

Objective I: To locate and summarise the current literature published on golf tourism worldwide (Chapter 4).

Objective II: To identify the characteristics of the international golfers who visit New Zealand, such as where golf tourists originate, their reasons for visiting, time spent in the country and their spending habits. 
Objective III: To investigate the size and nature of the golf tourism industry in New Zealand.

Objective IV: To provide an estimation on the economic benefits that international golf tourists bring to the New Zealand economy, as well as the effect that the current economic downturn is having on the industry. 


\section{Chapter 3}

\section{Methodology}

This thesis attempts to answer the research objectives by collecting information using a triangulating approach for data collection. Triangulation implies that the same phenomenon (i.e. golf tourism) is considered from more than one source of data in order to confirm the authenticity of each source (O'Leary, 2006) and is a valid approach that can give appropriate answers to research questions (Decrop, 1999).

For this study, a range of quantitative and qualitative research methods were used as well as the use of secondary research for a literature review. Primary information was gathered through interviews (qualitative) and the use of an anonymous questionnaire (both qualitative and quantitative).

\subsection{The Interviews}

Throughout the course of the research, 19 interviews and questionnaires were conducted and completed with a range of stakeholders across the golf tourism industry. One of these was with the manager of the Golf Tourism Cluster, six with golf course managers throughout New Zealand and 12 were with managers from companies who organise golf tours for overseas visitors. Also, 44 questionnaires were filled in by international golf tourists who visited New Zealand to play golf.

\subsection{Sampling Strategy}

When choosing which golf courses to interview, a purposive sampling technique was used. Participants were chosen based on how relevant they would be to the research project, and in this case only those courses that were perceived to attract a significant proportion of overseas players were contacted. This sampling technique is deemed reasonable for small sample qualitative research such as this (Marshall, 1996). For the golf tour operators, a similar method was employed, as well as the use of 
snowballing; where an existing interviewee recommends someone else to interview (O’Leary, 2006).

\subsection{Interview Technique}

All stakeholders were initially contacted by either email or phone to see if they were interested in taking part in the study. A time was then arranged and all interviews were conducted either face-to-face at their premises, or if this was not convenient, a time was arranged for a phone interview or else questions were sent via email. A faceto-face interview was the preferred interview method as visual clues from the interviewee helped to adapt the questions and to clarify certain questions when questions were not properly understood. This method of interviewing also helped the researcher and the interviewee get to know each other better, helping to create a more relaxed environment. However, this method was not always possible due to their location or if the interviewee was unable to meet while the author was in their area. Given the option, those who were unable to meet in person generally preferred to answer the questions in their own time via email.

While all golf course managers were interviewed on site and in person, of the remaining 13 interviews, eight were in person, four were conducted using email and one telephone interview. Face-to-face and telephone interviews yielded the most information out of all types of data collection. While email responses generally answered all questions asked, answers tended not to be as in depth. However, in some cases where email responses were not clear, an email was sent asking for further clarification.

Before a face-to-face interview commenced, a research information sheet was given to them explaining the aim and objectives of the thesis (Appendix A) as well as a consent form which gave them the option of being anonymously presented in the thesis or not (Appendix B). These forms were given approval by Victoria University's Human Ethics Committee (Appendix C). If respondents instead preferred to answer questions via email, the questions were emailed to them as a PDF attachment with the information sheet and consent forms to be read at the top of the attachment. This attachment used a number of text boxes and tick boxes for the tour operators to fill 
out, and then could be directly emailed back. The questions on this attachment can be found in Appendix D. For the telephone interview, information and consent was read out and given over the phone.

The questions asked to the golf tour operators and golf courses are listed in Appendix $\mathrm{D}$ and E respectively (the questions asked to golf tour operators in person were the same as those emailed). However, for face-to-face and telephone interviews the questions were not limited to these as the interviews were conducted in a semistructured format, allowing for a greater array of information to be obtained in a more relaxed and informal way. Interviewees could comment on issues they deemed to be important, and if they touched on what was believed to be an important issue, follow up questions were asked. All interviews were conducted between July and October 2009.

\subsection{The Golfer's Questionnaire}

Given the time and scope of this thesis, statistics from the Ministry of Tourism were used for a part of the quantitative analysis (see Chapter 5). However, these statistics did not contain all the required information to make certain comparisons, and a questionnaire aimed at international golfers visiting New Zealand was created to fill in these gaps. Also, a significant proportion of the information obtained from golf tour operators was average group data. The characteristics of individuals were not given, such as their reason for choosing New Zealand as a golfing destination, or their satisfaction level from their trip. The questionnaire therefore asks important questions such as:

- Their country of origin, age, gender, and annual income.

- What encourages (what are the pull factors) that determine why golfer travelled to New Zealand.

- What parts of their trip did they most / least enjoy?

- How long they spent in New Zealand, and the total number of golf courses played at. 
Some of these questions were included in the Ministry of Tourism's survey and similar answers here could be used to test the validity of the questionnaire's results. Also, while many tour operators gave estimations as to the demographics of their clients, very few were able to give exact figures. The inclusion of this information has allowed for a more rigorous quantitative analysis. The annual income of golfers was also asked for, as this was a common question asked in overseas studies and helps to determine their social status and spending habits. Much of the literature found on golf tourism focuses on the satisfaction level of tourists, so it was deemed important to include some basic questions to determine this for their New Zealand experience. Again, this was very useful for making comparisons to overseas destinations.

The questionnaire boasts a range of other questions, and these can be found at the back of this thesis in Appendix F. These questions give more information on the tourists golfing habits (such as how many rounds they play each year and their handicap), as well as similar questions asked to golf tour operators to back up the information gathered from them (e.g. the courses tourists visited).

During my literature review, I was unable to find any previous research on this topic. Previous studies conducted by Golf New Zealand have centred on domestic player numbers, membership and age. Similar questionnaires to this have been conducted overseas, and although most are on a larger scale, this questionnaire (combined with the Ministry of Tourism statistics) allows for a statistical analysis as well as comparisons to overseas studies on this topic.

It was determined that the most efficient way to collect questionnaires from international tourists was to enlist the help of golf tour operators. Similar to the questions emailed to golf tour operators, a PDF form was created using Adobe in which could be directly emailed to golfers. The recipients could then fill it out the form using a combination of tick boxes and text boxes, and then directly resend the form back. Email addresses were obtained either directly through willing golf tour operators, or else the form was given to the tour operators to email their clients directly. As the data was collected, the results were then entered into Excel for analysis. Given that these questionnaires were conducted during the winter months 
when golf tourism is at its minimum, only 44 questionnaires were collected. However, this was deemed sufficient given the quantity of information gathered from the other sources. 


\section{Chapter 4}

\section{Literature Review}

World tourism numbers have been steadily increasing for a number of decades and from 1950, total international arrivals throughout the world have been increasing at an annual average rate of $6.5 \%$, growing from 25 million to a total of 924 million in 2007. Tourism now accounts for $30 \%$ of total service exports worldwide, amounting to \$US 856 billion a year. While the current economic downturn has seen a decline in tourist numbers in 2009, from 2011 positive growth is forecast to return (UNWTO, 2009).

Figure 4: Total International Arrivals 1950-2008

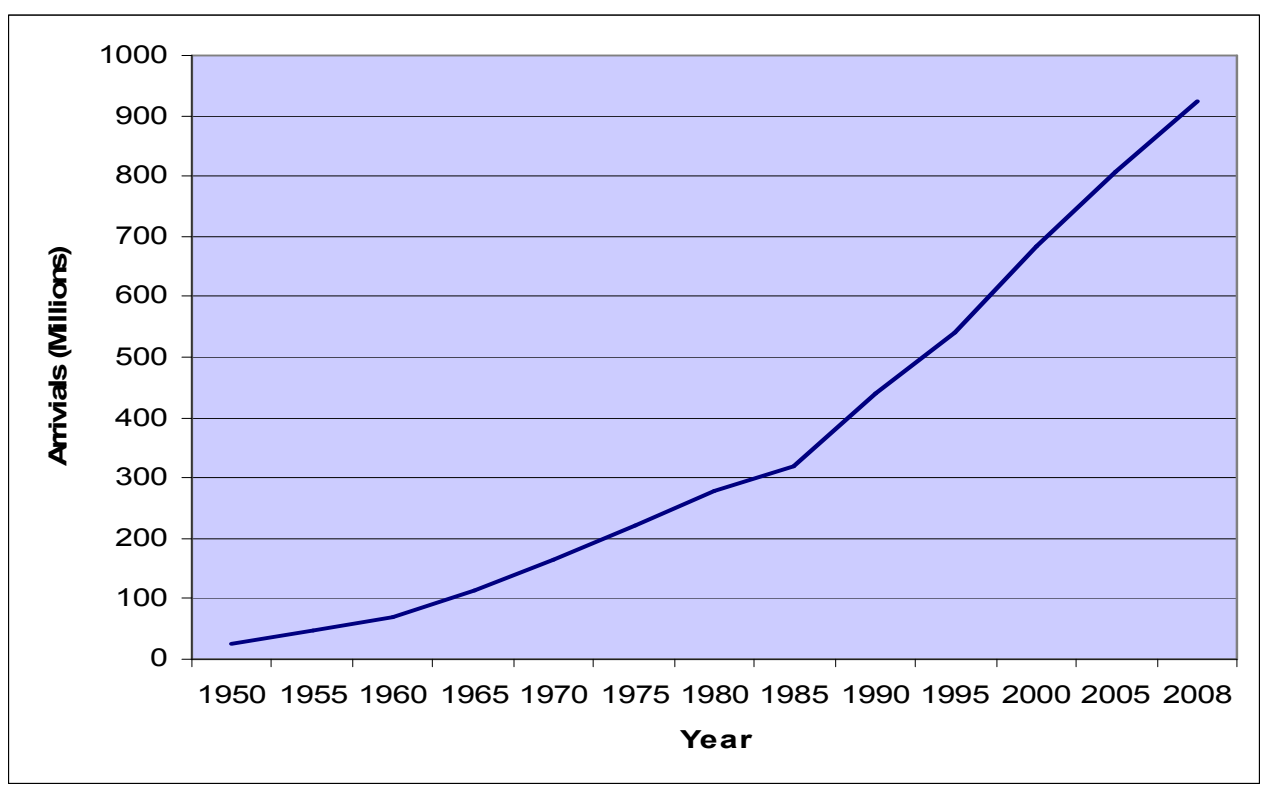

[Source: World Tourism Organisation, 2009]

Tourists travel away from their own country for a number of reasons and significant research has been done on the motivational factors that influence a person to travel. Zhang and Marcussen (2007) suggest that it is important to gain an in-depth analysis on tourists' motivations and activities in order to understand their destination choice. 
On top of this, an analysis can help to enhance destination image and its interaction with tourist satisfaction and loyalty.

Factors that motivate a person to travel away from home can be classified into two groups; push and pull factors. Push factors can be defined as the motivational influences on the individual. These are the psychological or intrinsic needs of an individual in which travel is a way where an individual can return to some kind of equilibrium. Examples include; escaping from social pressures, socialising/bonding, thrill seeking, the need for a learning experience, or even weather symptoms (Botha, Crompton and Kim, 1999). For instance, an individual may travel to a warmer climate during the winter to get away from the cold. This is considered as a demand-side approach to understanding a tourist's motivation for travelling (Kim and Lee, 2002).

On the other hand, pull factors can be viewed from the supply side. The number of attractions at a destination is considered to be the 'pull' mechanism which draws an individual to a particular destination. Examples that generally come under this definition include natural and cultural attractions, recreational activities (e.g. skiing and golf) and special events. Many destinations will have a range of attractions, however some will be reliant on a specific target market. By understanding the behaviour, wants and needs of tourists, it can better help those in a destination to plan, provide and improve necessary services, products and activities. On top of this, understanding tourists' motivations is useful in developing a market strategy in order to attract more people in the competitive market of tourism (Kim and Lee, 2002).

Once a tourist has made the decision to visit a destination, it is then important to have the correct services and infrastructure available to them, including transportation, accommodation, catering and shops (and often this will be taken into consideration by the tourist even before deciding where to travel). The main benefit from hosting tourists is the money they spend while in the country, however the social interaction between tourists and those living in the host country is often seen as beneficial and can help to educate those who live in the host country about the outside world (Newsome, Moore and Dowling, 2002). Essentially, what has been mentioned above can be put into a 'system' of inputs, processes and outputs, shown below. 


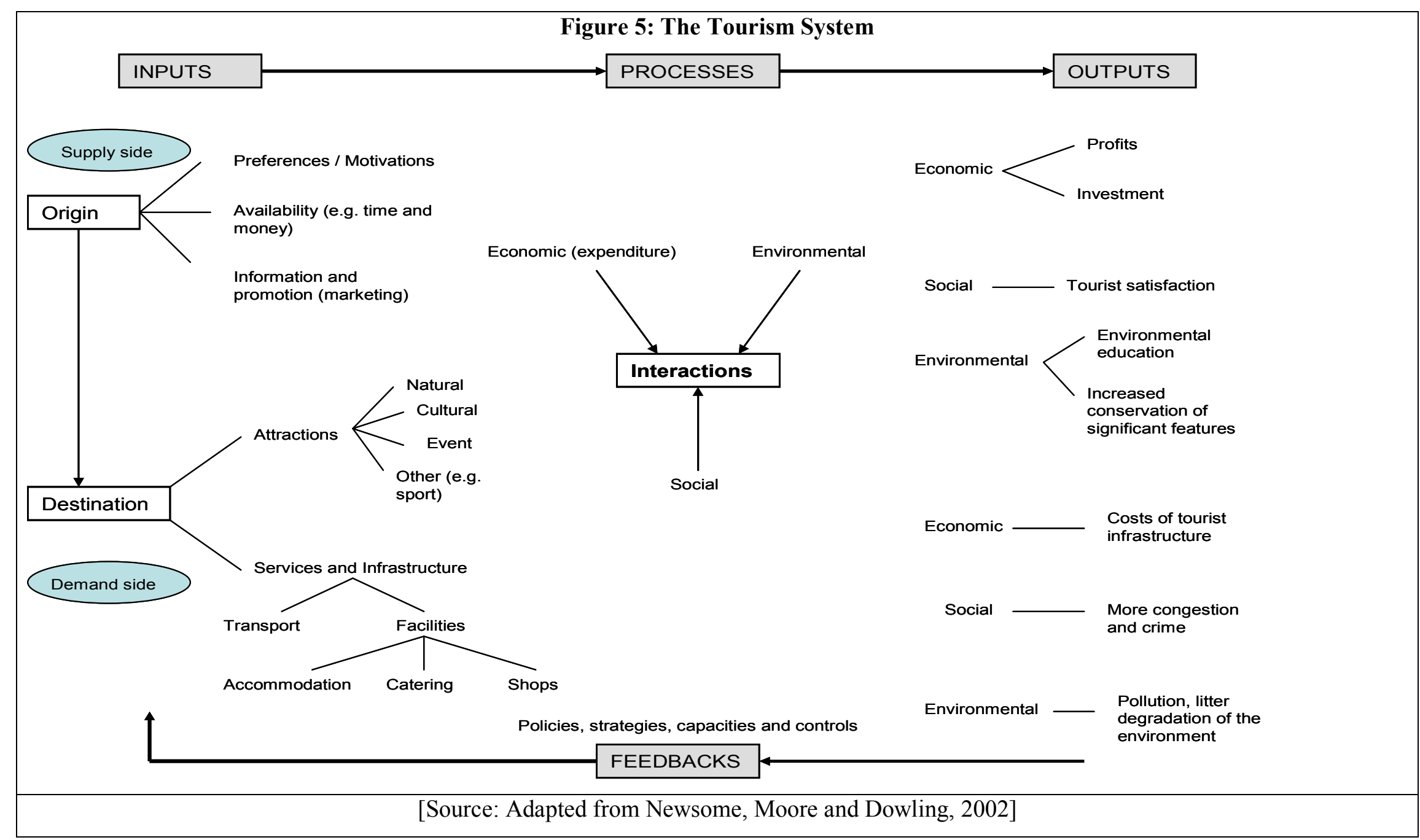


While only making up a small part of the above model, sport can be both a pull and a push factor for determining travel. Skiing is often thought to be the most popular form of sports tourism throughout the world and during the off season (the summer and autumn months) many people will often travel to the other side of the world in order to partake in the sport. Where tourists travel to will depend on the snow quality and facilities at their destination (pull factors) while the summer months (in the tourist's own country) can be thought of as a push factor. However, there exist a number of other sports in which tourists will travel long distances to either partake in or watch such as soccer (football), athletics, golf and many more.

While a tourist's push and pull factors are a common point of research, there has been a large shift towards developing more complex tourism theories. A more in depth analysis into the motivational and emotional traits of visitors have been developed involving a range of individual's psychological traits (Gnoth, 1997; McCabe, 2000). Other models have used microeconomic theory in an attempt to explain the behaviour of tourists, largely in the form of utility (satisfaction) maximisation (Morely, 1992).

However, while such complex models exist for tourism in general, their application has been limited for sports tourism research. Weed (2005) found that sports tourism research tended to focus on whether or not tourists enjoyed their experience rather than asking the underpinning reasons of why this was the case. It was found that sports tourism research lacks methodological diversity and in many cases does not employ any clear theoretical perspective. For literature on golf tourism, theoretical models are even less common with research predominantly being of a descriptive nature.

Sports tourism is a multi-billion dollar global business, and is considered to be the fastest growing sector of the tourism industry (Sportsbusiness, 2004). Sports tourism refers to travel away from home in order to watch or take part in sporting activities. This can be broken down into passive sports tourism, such as travel to watch sporting events and active sports tourism, where travel is for the purpose of actually participating in the sport or recreational activity (Delpy, 1997; Pitts, 1999; Hinch \& Higham, 2001). Evidence suggests that this form of tourism has grown in size in 
recent years and now forms an important segment of the tourism industry, amounting to over US \$45 billion per annum (Lavalle, 1997; Perry, 2004).

The increase in sports related travel has seen an increase in literature dedicated to the subject. In a systematic review of sports tourism research between 2000 and 2004, Weed (2006) found 80 articles linked to sports tourism, most of which (40\%) was directed at the impact of sports events tourism. Of these articles, only $4 \%$ covered golf tourism.

\section{Figure 6: The Small World of Golf Tourism Literature}

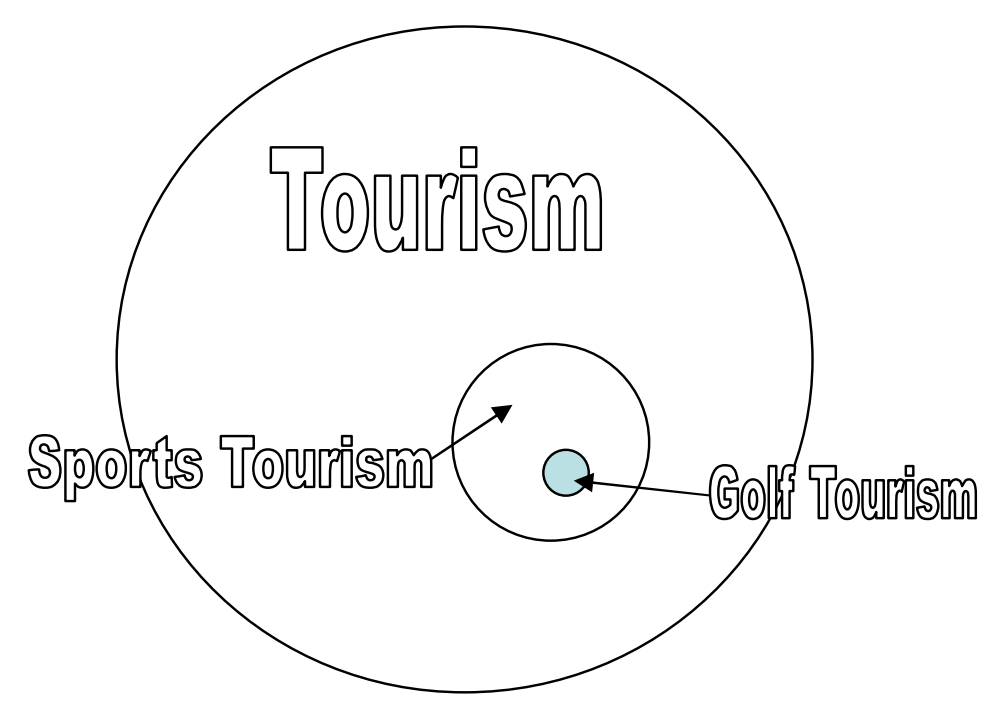

\subsection{Golf Tourism}

Golf is a niche market in sports tourism and is one of the fastest growing industries within it having large implications for countries where golf is a significant resource to the local economy (Tassiopoulos and Haydem, 2008). Golf tourism is estimated to add more than \$US 10 billion to the world economy each year. It is estimated that there are at least 60 million golfers located throughout the world with the popularity of golf rising quickly in recent years, and with this an influx in the number of tourists to golfing destinations (Readman, 2003, 165). 
The increase in demand for golf has in turn seen a rapid increase in the supply of golf courses worldwide. In the early 1990's it was estimated that there were approximately 26,000 golf courses worldwide (Golf Tourism Report, 2000), and today this number has grown to over 32,000 (Byrden, 2006). The number of courses in Europe has increased by over $60 \%$ since 1990 , while in the same period, Spain alone has seen the number of golf courses rise from 89 to 318 , an increase of $357 \%$ (EGA, 2009). There is little doubt that the increase in golf tourism has been a major cause in the construction of so many new courses (Napton and Laingen, 2008).

While golf is one of the fastest growing sports worldwide in terms of both supply and demand, research on the topic has not risen at the same rate and there remains a limited amount of academic literature on the subject. Of the literature that exists for golf tourism, there are two general areas covered. The first is the behavioural, demographics and motivations of golf tourists visiting a destination, while the second deals with the economic benefits golf tourists create. However, one problem that exists between all of these is a succinct definition of what actually constitutes a golf tourist. Examples include:

"Travel for non-commercial reasons to participate in golf activities away from the traveller's local environment" (Readman, 2003, 166).

"Golf tourism is the term used to describe trips undertaken by persons for which the main purpose is to play golf. Golf may also be pursued as a secondary activity (for example, someone on a beach holiday playing a round during their vacation" (One Caribbean, 2009).

"A golf trip is defined as a leisure trip taken within a country or crossborder, includes at least one overnight stay, and where the travellers main motivation is to play golf"' (KPMG, 2008, 22).

“A golf-related trip" (Haydu and Hodges, 2000, 5). 
"A trip in which a person travels 50-plus miles and plays golf while on this trip" (Golf 20/20, 2008, 22).

The main issue that arises from these definitions is whether those who pursue golf as a secondary activity should be included as 'golf tourists'. As with Golf 20/20's definition, should someone who plays one round of golf on a month long sightseeing holiday really constitute a golf tourist? Including such people will give different and more favourable economic results than those with a narrower definition. In an economic impact study of the Golf Industry in Georgia, Cooter, Papendick and Washington (2003) choose not to include the impact of golf tourism in their study, indicating that it is difficult to separate from other attractions, is an extension of a trip and is often not the cause or reason for non golf related expenditures (such as food, accommodation and airfares).

One attempted way of getting around this problem is by dividing the golfers and their results into sub categories. The Scottish Parliament Information Centre [SPIC] (2002) splits golf tourists into two categories; 'Golfing Holidaymakers' and 'Holiday Golfers.' Golfing Holidaymakers are those whom golf was the main reason for their holiday, while Holiday Golfers are those where golf played only a part in their travels. However, from the definitions above, a continuum has been created that best incorporates all definitions with the addition of a middle definition. In this case, golf is not the primary reason for taking a holiday; however it was a motivating factor in making the tourist's decision. An alternate destination may have been chosen had golf not been an option.

Figure 7: Golf Tourist Continuum

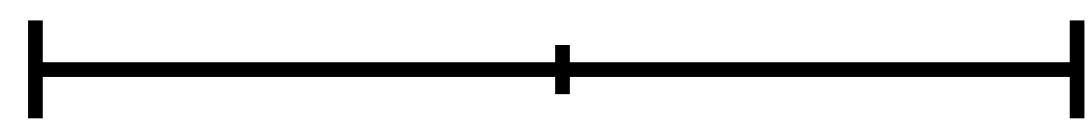

Type 1 Golf Tourist: Where golf was an activity enjoyed whilst on holiday, but not a factor for taking the holiday.
Type 2 Golf Tourist: Where golf was a motivating factor for taking a holiday, but not necessarily the primary reason.
Type 3 Golf Tourist: Where golf was the primary motivating factor for taking a holiday. 
These three definitions will be used constantly throughout this thesis.

\subsection{Economic Impacts of Golf Tourism}

With so many new golf courses opening worldwide, it is clear that golf is both a large and important part of the tourism industry. But how can we quantify this? Economic impact studies carried out in the United States (US), Africa, the Middle East and Europe have attempted to quantify the effects that golf tourists have on the local economy. Although numerous definitions of golf tourism exist and values must be taken with caution, the figures suggest golf tourism is big business and can result in large economic benefits.

\subsubsection{The Economic Impacts of Golf in the United States}

In 2005, Golf 20/20 (2008) estimate that the 'golf economy' in the US accounted for $\$ 195$ billion to the domestic economy, creating almost 2 million jobs. There has been a steady growth in the golfing economy of the US, with a $4.1 \%$ growth rate since 2000 , which is well about the average rate of inflation of $2.5 \%$. As a segment of the golf economy, golf related travel expenditure accounted for approximately $\$ 18$ billion in 2005 , at an average of $\$ 475$ per trip. However, when indirect and induced effects are taken into account, the effects of tourist expenditures are multiplied.

Visitors to a destination therefore impact the economy on a number of levels. Firstly, they impact the economy directly by their expenditures on green fees (the cost of a round of golf), food, accommodation, and transport. The indirect effects involve the money spent by the receiving industry, who then buys other goods and services with the money received by visitors. For example, the money received by the golf course is then spent to install an irrigation system for the golf course (Lahr, Grady \& Burch, 2007). Lastly, induced effects result from the personal consumption expenditures of the employees involved (from their wages). The resulting economic impacts are therefore more far reaching than simply the money spent by the golf tourist themselves (Haydu and Hodges, 2001). 
In an attempt to determine the economic impact of golf throughout the US, Golf 20/20 has commissioned a number of reports for individual states. The table below shows both the direct and total impact of golf related travel in each state. Golf tourism has the biggest economic influence in California, where it adds an estimated \$US 3 billion to the state's economy.

Table 2: Economic Impact of Golf Related Travel

\begin{tabular}{|l|r|r|r|r|}
\hline State & Direct Impacts (US\$ millions) & Indirect & Induced & Total (\$US millions) \\
\hline California & $1,245.30$ & & $\longrightarrow$ & $3,039.8$ \\
\hline Hawaii & 441.7 & $\longrightarrow$ & $\longrightarrow$ & 865.9 \\
\hline lowa & 100.4 & $\longrightarrow$ & $\longrightarrow$ & 206.8 \\
\hline Louisiana & 67.3 & $\longrightarrow$ & $\longrightarrow$ & 136.5 \\
\hline Massachusetts & 292.4 & $\longrightarrow$ & $\longrightarrow$ & 606.2 \\
\hline Michigan & 632.4 & $\longrightarrow$ & $\longrightarrow$ & 1334.7 \\
\hline Minnesota & 360.5 & $\longrightarrow$ & $\longrightarrow$ & 822.3 \\
\hline North Carolina & 507.8 & $\longrightarrow$ & $\longrightarrow$ & 1096.3 \\
\hline Ohio & 520.7 & $\longrightarrow$ & $\longrightarrow$ & 1205.6 \\
\hline Texas & 758.2 & & $\longrightarrow$ & 1882.2 \\
\hline Virginia & 329.1 & $\longrightarrow$ & $\longrightarrow$ & 678.5 \\
\hline
\end{tabular}

[Source: Golf 20/20, 2009]

It needs to be noted however, that all of these results come from using a wide definition of golf tourism (a 'Type 1' golf tourist), and therefore the benefits may be overstated when compared to other studies.

\subsubsection{Economic Impact in Europe, The Middle East and Africa}

By far the largest research into the impact of golf is KPMG's 'Golf Benchmark', designed to collect, share and provide golf market analysis on a number golf related issues such as golf facility operations, golf course capital investments, supplies, tournaments and endorsement, golf real estate and golf tourism (Golfbenchmark, 2009). For the year 2006, KPMG released a study on the value on golf to Europe, the 
Middle East and Africa (EMA), compiling together over 1500 surveys and personal interviews. During that year, the golf industry in the EMA was estimated to have generated a total of $€ 21$ billion to the region, with a large proportion being split between the three segments of golf facility operations, golf real estate and golf tourism. However, once the indirect effects are accounted for, golf's total economic value for the area is as much as $€ 53$ billion, supporting almost 450,000 jobs (KPMG, 2008a).

Golf tourism in the EMA has developed into a successful niche market and there exist numerous tour operators tailoring for the needs of golfers throughout the world In addition to the increased demand for golf, the growth of low cost air travel throughout Europe in recent years has helped to make golf courses throughout the region much more accessible (Golf 20/20, 2008; KPMG, 2008a).

In 2006, it is estimated that between 1 and $1.5 \%$ of leisure trips taken in the EMA region were golf related, and $90 \%$ of these travellers originated from the EMA region. For the purpose of the study, a golf trip was defined as a trip that includes at least one over night stay, and where the primary motivation for taking the trip was to play golf (KPMG, 2008a). This is a much narrower definition (a Type 3 golf tourist) than used in the US studies. The estimated revenue to the EMA economy from golf tourism is $€ 6.5$ billion per annum and supports approximately 60,000 jobs. Over half of golf tourism related revenue occurred in Western Europe, even though the area contains only $16 \%$ of the total number of golf courses in the EMA, while surprisingly, Great Britain and Ireland received only $12 \%$ of tourism revenue despite being home to $40 \%$ of the regions golf courses (KPMG, 2008a).

The number of golf courses throughout Europe has been rising at a rapid rate since 1990 to cope with the increased demand for golf both throughout Europe and worldwide. The table below shows this increase for individual European countries. 
Table 3: Total Number of Golf Courses in Europe, 1990 and 2008

\begin{tabular}{|l|r|r|r|}
\hline Country & Courses (1990) & Courses (2008) & \% Change \\
\hline Scotland & 485 & 578 & 119 \\
\hline England & 1,350 & 1,897 & 141 \\
\hline Ireland & 271 & 414 & 153 \\
\hline France & 305 & 559 & 183 \\
\hline Sweden & 207 & 462 & 223 \\
\hline Germany & 290 & 684 & 236 \\
\hline Switzerland & 38 & 94 & 247 \\
\hline Italy & 101 & 258 & 255 \\
\hline Austria & 42 & 149 & 355 \\
\hline Spain & 89 & 318 & 357 \\
\hline Portugal & 21 & 78 & 371 \\
\hline Czech Republic & 8 & 74 & 925 \\
\hline
\end{tabular}

[Source: EGA, 2009]

Of these, Portugal and Spain are possibly the two main countries who have benefited from an increase in international golf visitors. In Portugal, golf courses are predominately located in the Algarve region in the South. In 2002 more than 200,000 golfers visited the region, with an average daily expenditure of $€ 175$, giving a direct economic impact of $€ 35$ million per year (Videria et al, 2006). KPMG (2008a) have predicted that Spain and Portugal will be the future hotspots for golf tourism, making them the most popular destinations in the years ahead. 
Figure 8: Monte-Rei Golf and Country Club in Portugal - A Jack Nicklaus Design

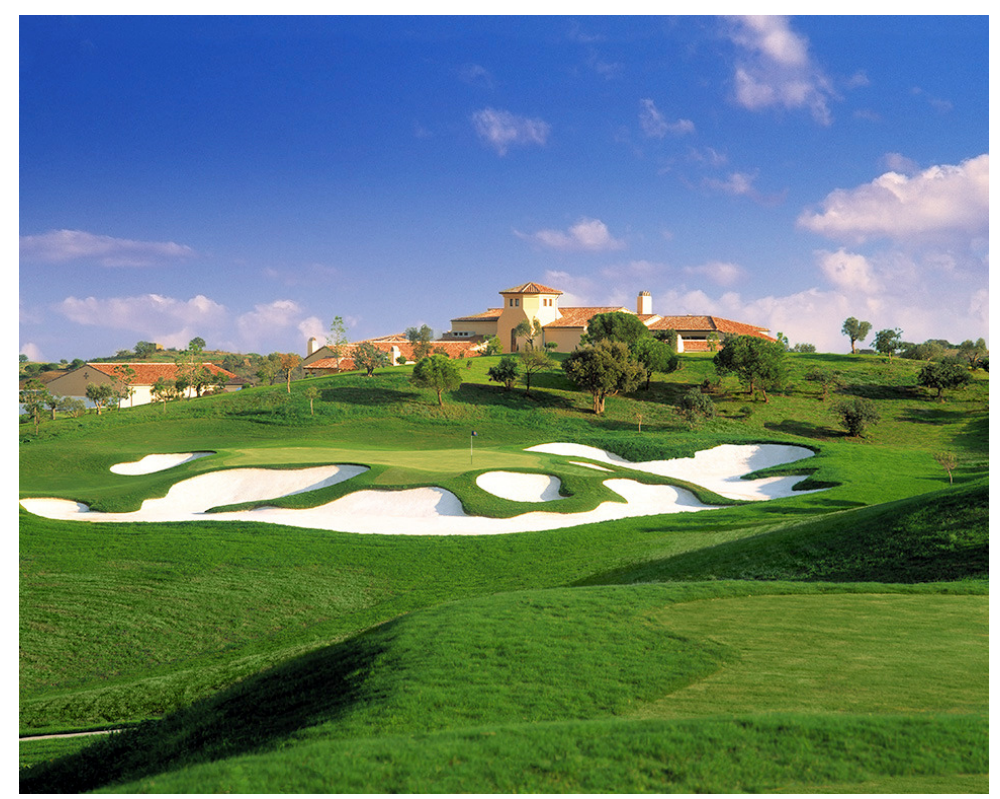

[Source: Monte-Rei, 2009]

While not growing at the same rate as emerging destinations such as Portugal and Spain, Scotland has been a popular golf tourist destination for some time, with the Scottish government being heavily involved in its promotion. A number of agencies such as 'Visit Scotland' and 'Golf Tourism Scotland' have been set up to promote and research golf tourism in the country (Visit Scotland, 2009).

It is generally accepted worldwide that the origins of golf originated in Scotland in medieval times and references to the game were even made in acts of parliament during the $15^{\text {th }}$ Century. On the eastern coast of Scotland, players would hit pebbles over a 'course' of sand dunes and into rabbit holes using a stick, or the resemblance of a primitive golf club. However, the sport was banned in 1457 by the Scottish Parliament because it was seen to be detrimental to more important activities such as archery. The ban was reaffirmed in 1491 and 1502, although in 1502 the ban was over turned by King James IV who began playing and devoting time to the game of golf (Macintyre, 2007; SPIC, 2002).

Known as the "home of golf," Scotland has used its rich golfing history as a way to entice visitors to the country. One of the most famous courses in Scotland is the St 
Andrew's Old Course, formed in 1754. It is home to the Royal and Ancient Golf Club, golf's governing body and people come from all over the world to play at the world's oldest surviving golf course (R\&A, 2009). On top of this, Scotland boasts in excess of 500 courses between five million people, giving them the honour of having the most golf courses per head of population in the world (Bond, 2007). Golf tourism is therefore an important part of Scotland's tourism industry with approximately $8 \%$ of visitors playing the game while in the country, amounting to approximately 242,000 people each year (SPIC, 2002).

\section{Figure 9: The $18^{\text {th }}$ Hole at St Andrews, the world's oldest surviving golf club}

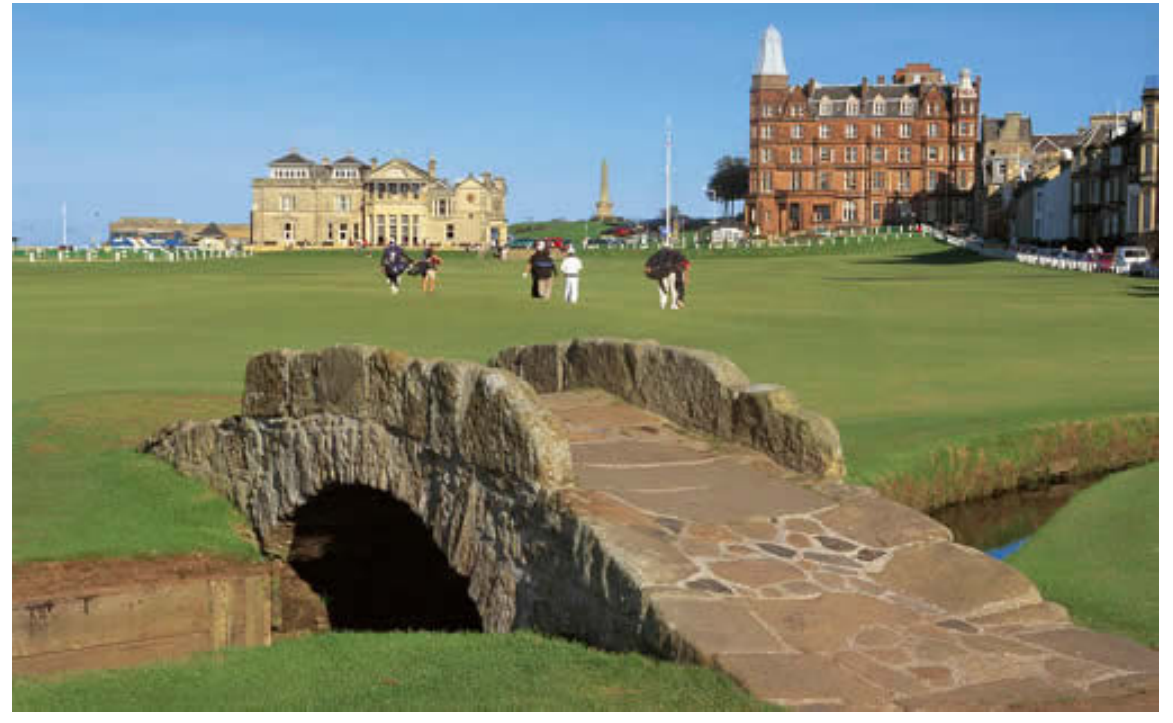

[Source: Heritage School, 2009]

A report conducted by the Scottish Parliament on golf and business tourism found golf tourism to be directly worth around $£ 100$ million to the Scottish economy annually, of which $£ 70$ million is spent by visitors from the United Kingdom (UK) and the rest being spent by overseas golfers (SPIC, 2002). While Scotland has always been a major player in the international golf tourist market, they can no longer rely on their historical reputation as the 'home of golf'. The rise of other destinations throughout the world has seen Scotland's share of the global golfing market decline during the 1990s. In the early 1990s, Scotland was the most popular golfing destination for UK visitors; however by the end of the decade, Scotland had fallen to fourth place behind England, Spain and Portugal (SPIC, 2002). 
In interviews carried out with tour operators, it was in their view that Scotland's reputation was not sufficient to ensure repeat business. More was required to attract visitors back to the country and one way of achieving this was to spread golf tourism away from signature courses, playing at smaller less known courses throughout the country. The major market for tour operators in Scotland is affluent male Americans however in the future there is an expected trend of an increase in shorter breaks from continental Europe, as long as rising costs do not inhibit golfing tourists (Golf Tourism Monitor, 2010).

When asked about the future, $82 \%$ of golf tour operators in the EMA region expect that the number of golf trips will steadily increase in the forthcoming years (KPMG, 2008b). Portugal, Spain, Turkey and Dubai were the top destinations mentioned in the years ahead, which is no surprise when considering the importance of a country's climate in a golf tourist's decision of where to travel (this will be further discussed later on in this chapter). Countries such as Thailand, Malaysia and Indonesia were also considered to be emerging destinations in the golf tourism market. Stagnation is expected in traditional destination such as Scotland and Ireland due to increased competition from abroad. However, it must be mentioned that these results were found prior to the economic and financial crisis, and therefore it is likely a different result would have occurred had tour operators been questioned at a later date (KPMG, 2008b).

\subsubsection{Economic Impact in Australia}

In 2004, the Australian PGA commissioned a report similar to those above into the economic impact of golf on the Australian economy. It was found that in 2004, the golf industry generated an estimated \$A 2.71 billion to the national economy and it is estimated that 23,000 are directly employed in the industry. The tourism component of this was estimated to directly add \$A 425.5 million to the economy. International golf tourists were estimated to stay for a duration of 45 days, playing golf on $10 \%$ of those days (PGA Australia, 2006). 


\subsection{Golf Tourist's Behaviour, Motivations and Demographics}

The other area of golf tourism research deals with market segmentation, of which includes the behaviours, demographics and motivations of golf tourists (Hennessey, MacDonald \& MacEachern, 2006). Behavioural aspects have been successfully used in the past and are considered a valid approach to use for niche offerings such as golf (Litvin, 2000). Questions asked therefore include; how long do golfers travel away from home for, how many rounds of golf they play, how much they spend, their reasons for choosing a specific destination and their age.

Possibly the most important aspects of golf tourism, especially in terms of marketing, are the origins of golf tourists and their reasons for visiting. Research in a number of countries has attempted to answer this. In Scotland the key international golf markets (not including other UK countries) were the United States (39\%) and Sweden (14\%), with Germany, Norway and Finland also making sizeable contributions (SPIC, 2002). A similar pattern emerges for Ireland as their largest market is North America with a $60 \%$ share of golfing visitors coming from here (SPIC, 2002).

In Australia, Tourism Victoria (2008) profiled international golfers visiting the state of Victoria in a three year period between 2004 and 2007. The graph below shows the origins of golf visitors, with Asia being the largest market with an estimated share of $29 \%$ (32\% including Japan), accounting for 10,400 golfers. 
Figure 10: Origins of Golf Visitors to Victoria, Australia

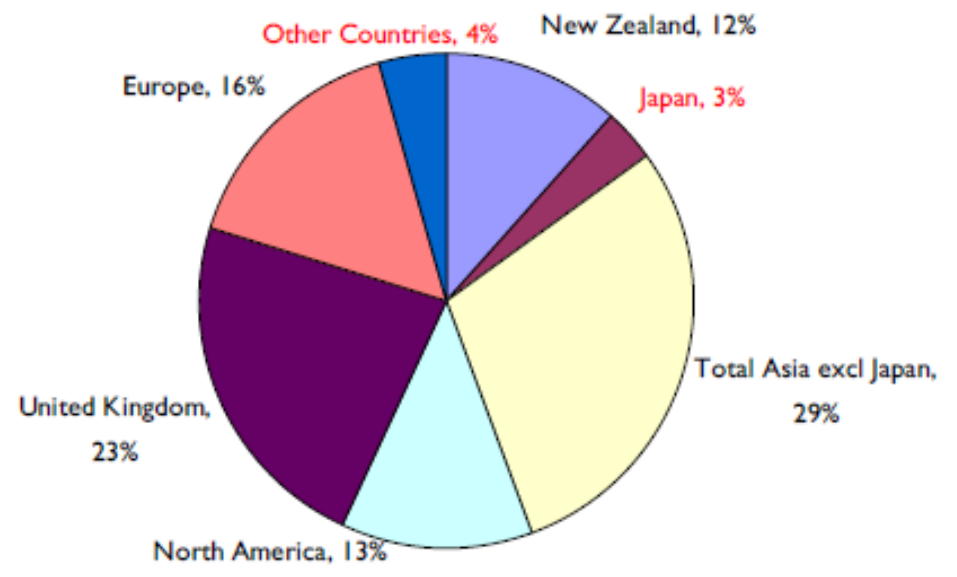

[Source: Tourism Victoria, 2008]

The country of origin for golf tourists follows a similar pattern to general tourism for Australia, with only New Zealand and the United Kingdom having noticeable differences, as shown in Table 4 below.

Table 4: Origin of golf tourists and general tourists visiting Australia

\begin{tabular}{|l|r|r|}
\hline Country & Golf Tourists & General Tourists \\
\hline Asia & $32 \%$ & $34 \%$ \\
\hline New Zealand & $12 \%$ & $19 \%$ \\
\hline United Kingdom & $23 \%$ & $12 \%$ \\
\hline Europe & $16 \%$ & $12 \%$ \\
\hline North America & $13 \%$ & $10 \%$ \\
\hline Other & $4 \%$ & $13 \%$ \\
\hline
\end{tabular}

[Source: Tourism Australia, 2010]

Geography also plays an important role in understanding a golfer's motivations or reasons for travelling to a particular country. In KPMG's (2008a) EMA report, golf tourists were asked the importance of the various pull factors taken into consideration when choosing a destination. While it is no surprise that climate, course quality and price were the most important pull factors, surprisingly sightseeing opportunities ranked the lowest of all 11 factors (KPMG, 2008a). The factors and their importance are shown in the graph below: 


\section{Figure 11: Factors influencing Travel to a Golfing Destination}

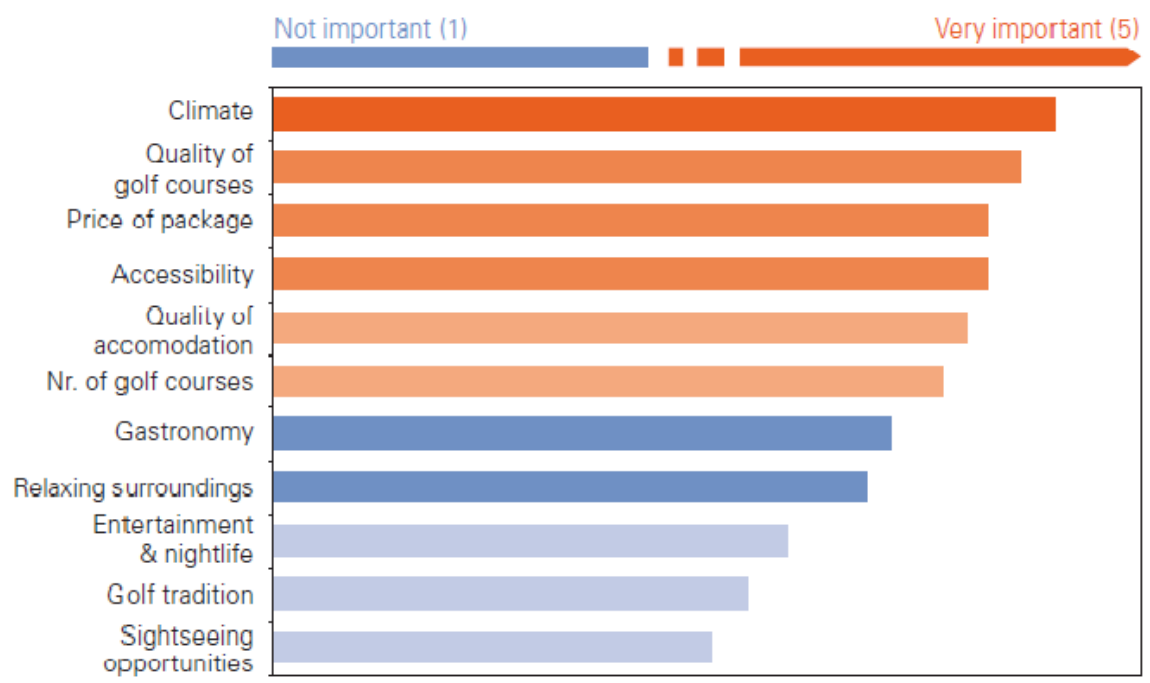

[Source: KPMG, 2008a]

The climates of Spain and Portugal indicate why they are such highly regarded golfing destinations. Temperatures in these countries reach well over 30 degrees $\mathrm{C}^{\mathbf{0}}$ in the summer months with plenty of sunshine hours and only a small amount of precipitation. In the southern regions in winter, temperatures also tend not to fall too low and as a result, golf can be played all year round. In countries such as Canada and Scotland, the weather is much less settled and has a far greater impact on golf and golf tourism. Table 5 and Figures 12 and 13 show the average summer temperatures in certain cities throughout the world as well as average precipitation levels and yearly sunshine hours. Average summer temperatures and precipitation levels are for July in the Northern Hemisphere, and January in the South.

Seville (Spain) and Lisbon (Portugal) are two cities with high summer temperatures, many sunshine hours and low levels of precipitation. As a result their surrounding areas have seen a dramatic rise in the number of golf courses. While many other cities have summer temperatures in the mid 20's, precipitation levels are much higher. In winter these places remain relatively mild however, in Scotland and Canada temperatures remain low. This has the largest impact in Canada where a large number of golf courses close down during the winter months due to snowfall. 
However, the weather is not the only reason why Spain and Portugal are seen as successful golfing destinations. Geography also plays an important role. These countries, as well as others in Europe, are all located near or share borders to numerous other countries resulting in a high number of potential golf tourists within a small proximity. The geographical location of the country will also have an impact on the type of tourist who visits.

Based on information from tour operators, the typical tourist in the EMA region spends between four and seven days away while on a short haul trip, and 7-14 days while on a long haul one. During a week long holiday, a typical tourist plays between four and six rounds of golf and plays at an average of four different golf courses (KPMG, 2008a). Therefore golfers in the EMA travel on short trips, playing golf on a high percentage of days (making them a 'Type 3' golf tourist). 
Table 5: Weather Comparisons for Golfing Destinations throughout the World

\begin{tabular}{|l|l|r|r|r|r|}
\hline City & Country & Summer Temp(deg C) & Winter Temp (deg C) & Summer Rainfall (mm) & Yearly sunshine hours \\
\hline Edinburgh & Scotland & 18 & 6 & \\
\hline Vancouver & Canada & 23 & 5 & 1380 \\
\hline Auckland & New Zealand & 23 & 14 & 1920 \\
\hline Sydney & Australia & 26 & 16 & 2110 \\
\hline Lisbon & Portugal & 27 & 14 & 2420 \\
\hline Seville & Spain & 36 & 15 & 3020 \\
\hline
\end{tabular}

[Source: BBC, 2009]

Figure 12: Temperature and Rainfall in Golfing Destinations

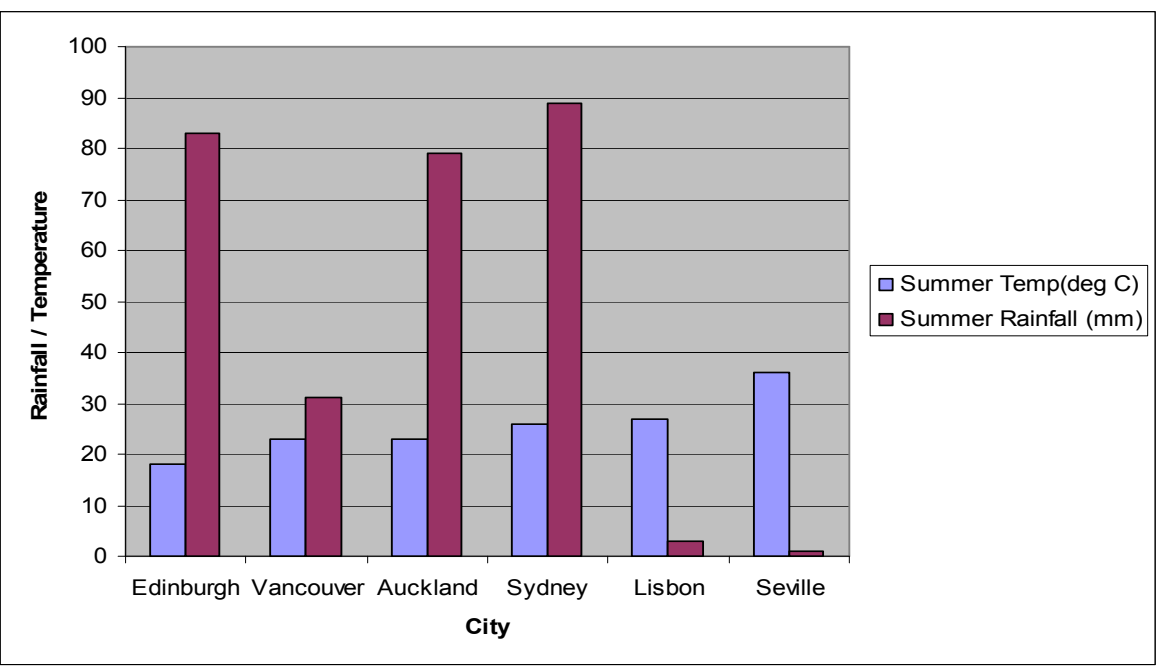

Figure 13: Sunshine Hours in Golfing Destinations

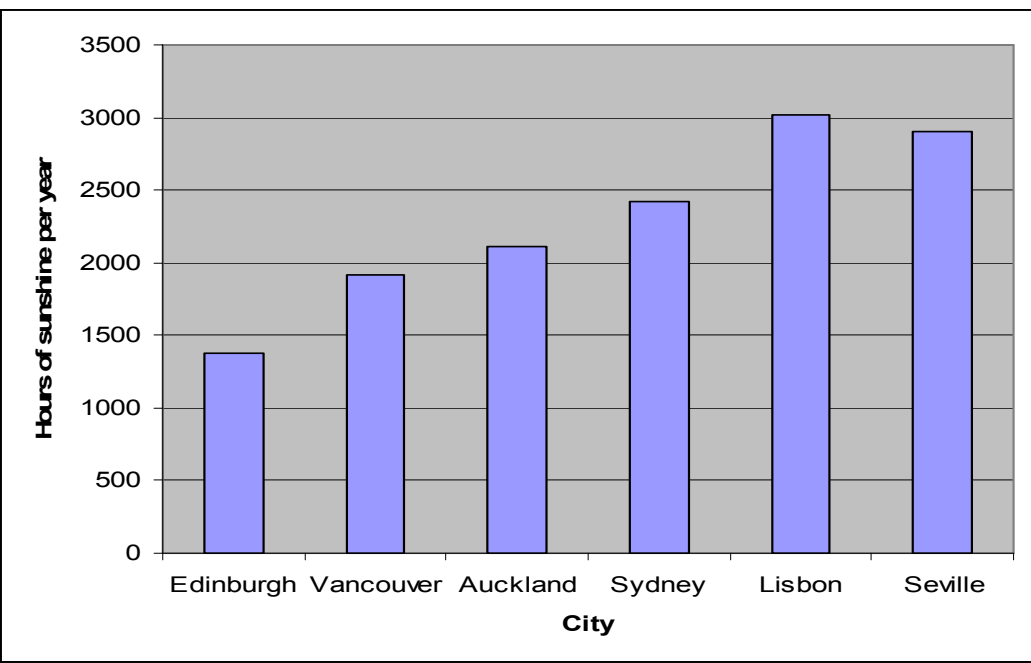


In more geographically remote locations, such as Australia and Hawaii, trip length is typically much longer, sightseeing plays a greater role and golf play is less intensive. As mentioned before, in Australia the average international golf tourist stayed for 45 days, playing golf on just $10 \%$ of these days (PGA Australia, 2006). In Hawaii, golf tourists participate in other activities rather than just golf. $45 \%$ participated (or planned to participate) in snorkelling and scuba diving while 54\% planned to visit the beach or go sightseeing (HVCB, 2003). Thus golfers visiting remote geographical locations tend to do more than just golf. Golf is less likely to be the primary factor and tourists are more likely to be 'Type 1' or 'Type 2' golf tourists. A similar pattern emerges for Scotland when comparing UK visitors versus those from further abroad. Overseas golfers tend to spend 10 nights in Scotland, whereas those from the UK spend just five (SPIC, 2002).

Not only do golf tourists spend longer at a destination, they are older, are of a higher social class and spend more while on their trip (Weed and Bull, 2004). While the average sports tourist is generally a young 18 to 44 year old with a household income of more than US $\$ 40,000$, golfers tend to be older, male and even more affluent than their sport tourist counterparts (Delpy, 1997). In Michigan, the average golf tourist was aged 44, with a third reporting incomes of more than US \$100,000 (Stynes, Sun and Telhelm 2000). Three quarters of golf tourists visiting South Africa were aged between 36 and 50 years old, 79\% of which were male (Tassiopoulos et al, 2008).

While a majority of golf tourism literature has focused on the behaviour of golf tourists, Gibson \& Pennington (2005) have attempted to explain their underlying behaviour using role theory. Role theory is mainly used in sociology where a role can be defined as "a collection of behaviours that have some sense of cohesiveness and relatedness to a social position" (Gibson and Pennington, 2005, 446). For example, the roles taken in a family's life style will have an impact on tourist behaviour. The presence and age of children as well as disposable income are important factors that shape the type of holiday people take. Lawson (1991) found that with younger children, holidays revolved around visiting relatives and only visiting one place at a time. However, once their children became more independent, more active holidays (i.e. golf) were taken. This could help to partly explain why a large proportion of golfers tend to be much older than the average tourist. 
Golf tourists can also be segmented by their golfing characteristics and combined with the tourists demographics, this is referred to as the individuals "golfographics." Golfographics encompasses factors such as gender, age, total number of rounds played annually, handicap, income and where they play their golf (Worldgolf, 2009). This helps to model the profile of a visiting golfer and sets a good framework for a better understanding of their behaviour (Hennessey et al, 2006). In Scotland, golfing holidaymakers tended to be mostly larger male groups consisting of an average of 11 people, be lower handicap golfers (with over 20 years experience) and play golf on everyday of their stay. Meanwhile, holiday golfers were mixed-sex smaller groups (an average of five per group), many of whom did not even have a handicap. Although they tended to stay in Scotland for a longer period of time, they would only play golf on every second or third day (SPIC, 2002).

While golf tourists tend to be richer and spend more than the average tourist, the golf industry only receives a small proportion of the economic benefits. Findings suggest golf accounts for only $15-25 \%$ of total expenditure. For every $\$ 1$ spent on green fees, up to a further $\$ 5$ is spent in shops, restaurants, transport and accommodation (Bond, 2007). In the EMA region, average spending was distributed as outlined in Figure 14.

Figure 14: Spending of Golf Tourists in the EMA Region

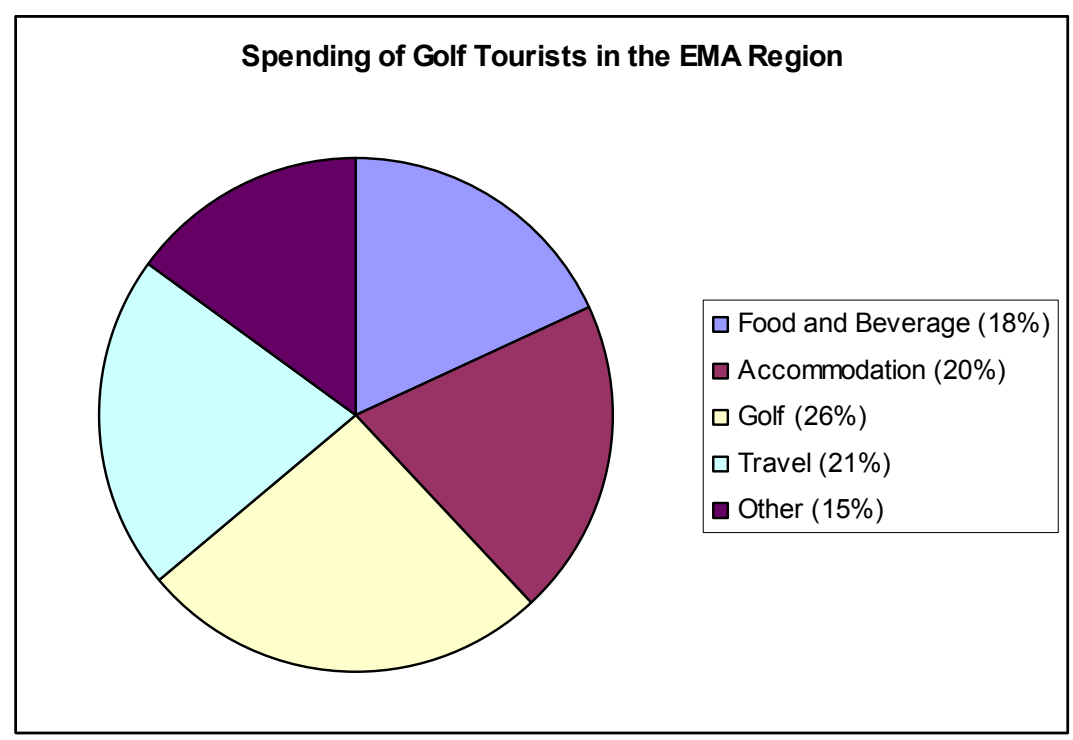

[Source: KPMG, 2008a] 
At the same time, KPMG released a report on golf tourism trends in the EMA region in which 80 golf tour operators were interviewed. In the past decade, $73 \%$ of operators reported an increase in the number of golf tourists, which is no surprise given the increase in demand for golf during the same period. While on holiday, the average golf tourist spends $€ 150-180$ a day on a short trip, and $€ 250$ a day whilst on a long haul trip (KPMG, 2008a; KPMG, 2008b).

\subsection{The Recession}

Golf tourism is worth over \$10 billion worldwide and between 1998 and 1999, the value of golf tourism increased by $8 \%$. However, 2008 saw the beginnings of an economic downtown affecting nearly every industry worldwide. Growth in the global tourism industry has slowed from 3.4\% per year in the $2004-2007$ period, to just $1 \%$ in 2008. The industry is expected to contract by more than 3\% in 2009 (World Travel and Tourism Council, 2009).

As a result, we may expect to see a similar downturn in golf tourist numbers however, it has been suggested by some that golf is "recession proof." Golfers become so caught up with the game that general economic principles tend to be discarded (Klein, 2009). Simple economics would suggest that for a luxury good such as golf, lower incomes will result in lower demand. However, it is widely believed that demand for golf is 'income inelastic,' that is, changes in income have no (or very little) affect on consumers demand to play golf.

In a US study using golf ball purchases as a proxy for the number of rounds played, Lynch (2008) finds that while golf is not entirely recession proof, it is resilient and is one of the last industries to be affected and one of the first to rise again after a recession. However, the effects of the current recession are being felt in Scotland and Ireland with a number of courses having to lay off staff in order to counter the effects of reduced spending, as seen by a sharp downtown in corporate event days at these courses (Nesbitt \& Woodifield, 2009). Golf club makers such as Calloway are also feeling the effects of the recession. In 2008 , their revenues deceased by $22 \%$, leading to a net loss of \$US 2.5 million (Aclant, 2009). 
In the US, the National Golf Foundation (NGF) researched the effects the recession was having on the golf industry. However, the results give some contradictory results. Using golf operator surveys, $38 \%$ of golf operators expected an increase in revenue for 2008 , while only $35 \%$ expected revenues to fall. On the contrary, core golfers (those who play more than eight rounds of golf a year) have cut their spending on green fees and golf merchandise by 25\% (CMMA, 2008). As a part of this, golf travel has also been negatively impacted with approximately $18 \%$ of core US golfers participating in fewer golf trips, shown in the table below.

Table 6: Core Golfers in the US - Spending Effects of the Recession

\begin{tabular}{|l|l|l|}
\hline Golf-Related Spending/ Activity & March 2008 & August 2008 \\
\hline Playing fewer rounds & $19 \%$ & $23 \%$ \\
\hline Delaying equipment purchases & $25 \%$ & $24 \%$ \\
\hline Going on fewer golf trips & $\mathbf{1 8 \%}$ & $\mathbf{1 7 \%}$ \\
\hline None of the above & $55 \%$ & $53 \%$ \\
\hline
\end{tabular}

[Source: NGF, 2009]

\subsection{Summary}

Each year, a significant number of tourists are travelling away from their home country to partake in the game of golf. The increase in demand for golf worldwide has seen the supply of golf courses increase at an exponential rate and the world wide economic expenditure of golf tourists now amounts to billions of dollars each year.

Climate, the quality of golf courses and price are the three main pull factors that influence a golfer's decision on where to travel. Because of the warm climates of Spain and Portugal, these countries are quickly becoming some of the most popular destinations for international golfers. Meanwhile, cooler countries such as Scotland who previously relied heavily on the history of golf in the country are not seeing the same increases found in the Mediterranean. 
While this chapter has focused on destinations from all over the world, it has not included any literature or information on the tourism or golf industry in New Zealand. This will be looked at in the following chapter. 


\section{Chapter 5}

\section{Golf and Tourism in New Zealand}

The first golf course in New Zealand was the Otago Golf Club, opening in 1871 and the game quickly spread throughout the country. By 1939 there existed 328 affiliated golf clubs with 29,000 registered players and since then, this number has grown to more than 130,000 . Now almost 500,000 people play the game of golf every year (both registered and casual) making it the most popular sport in this country in terms of participation rates (NZGA, 2009). This is no surprise given that the relative cost of playing golf in New Zealand is cheaper than many other countries, and that New Zealand is only second to Scotland in the number of golf courses per head of population (Golf Digest, 2007).

However, membership numbers in New Zealand have been declining in recent years. In the past five years, membership numbers have declined by a total of 10,000; although overall player numbers have not been negatively affected due to an increase in casual players (NZGA, 2009).

New Zealand's low density population and high number of courses gives the opportunity for anyone in the country to play golf if they wish to do so, unlike countries such as Japan where cost and space make playing the game only for those who can afford the luxury of doing so (Kunihiro, 1990). Every year, approximately 500,000 New Zealanders play golf, equating to almost $13 \%$ of the population. This is higher than more traditional sports such as cricket (7.3\%) and soccer (6.9\%) as shown in Figure 15 below (Sparc, 2009). 
Figure 15: New Zealand's Yearly Sports Participation Rates

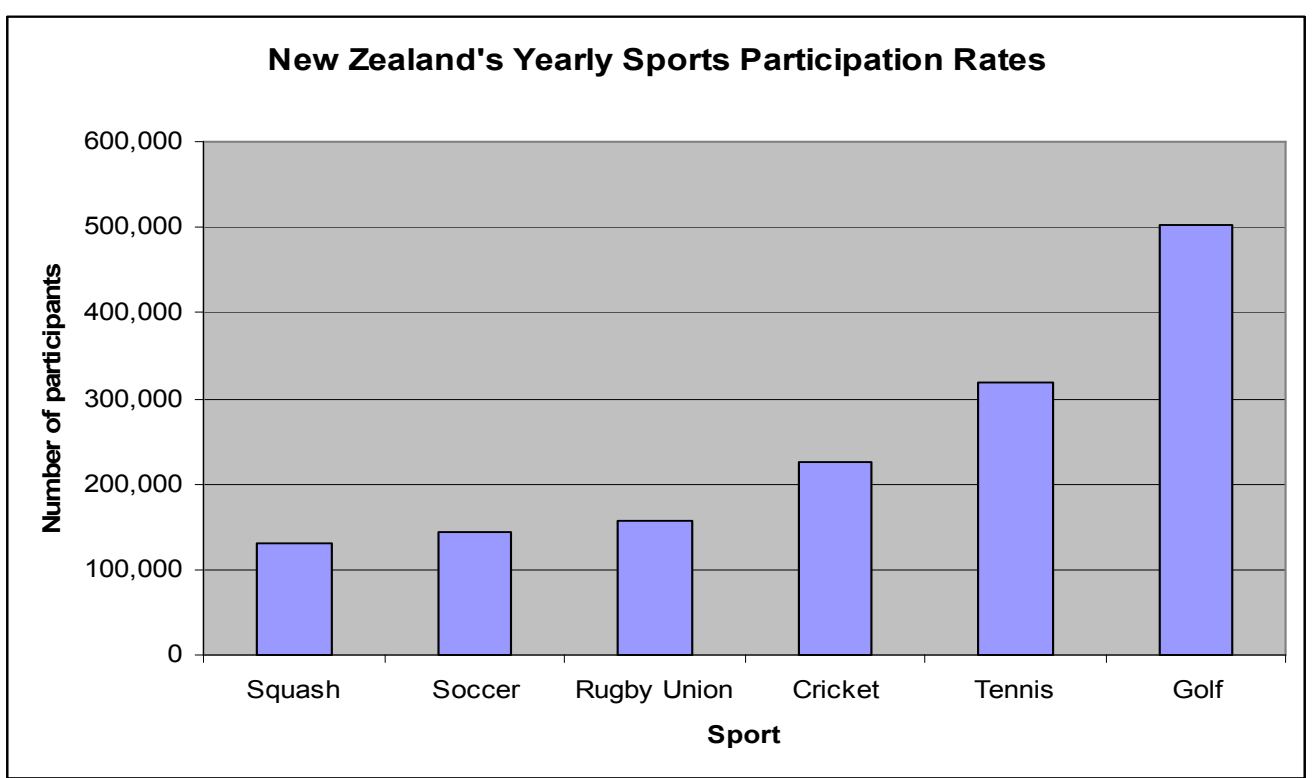

[Source: Sparc, 2009]

While many courses constructed over the last century were simply for golf, there has been a shift in recent times to a golf focused community, where a resort, conference facilities and residential development are built around new courses. The golf course is primarily built to increase the attractiveness of the area and therefore increasing the real estate value of the surrounding land. Research suggests that land value within a close proximity to a golf course is increased by as much as $26 \%$ (Nicholls \& Crompton, 2007, 555) and in the US, more than 1,000 such developments were built between 1972 and 1984 (Adams \& Rooney, 1985, 420). Since then, the rate has increased even further and during the 1990's more than 3,000 were constructed (Nicholls \& Crompton, 2005, 38).

Many such developments have happened in New Zealand in the past few decades. Examples include; Millbrook Resort and Jacks Point in Queenstown, Clearwater in Christchurch, Terrace Downs in the Canterbury High Country, Pauanui Lakes in the Coromandel, Carrington in Northland and Kinloch near Taupo. In addition to this, a new course has recently opened in Pegasus near Christchurch and a new course is scheduled to be built in Gibbston valley near Queenstown. Also, Cape Kidnappers 
(Hawkes Bay) and Kauri Cliffs (Northland) have accommodation attached to the course. The number of new and proposed golf courses and resorts that have been planned and built in New Zealand in recent years has likely impacted the number of visitors coming to play golf in this country.

New Zealand is host to two international golf tournaments each year which are televised throughout the world. Currently, the New Zealand PGA is held at Clearwater Resort in Christchurch in January while in 2010, the New Zealand Open was held at the Hills golf course near Queenstown. Estimates regarding the economic benefits from these tournaments are high, with the 2010 New Zealand Open expected to add around $\$ 8$ million in direct spending and more than $\$ 20$ million in total (Fea, 2010). If these televised events help to show case New Zealand as a golfing destination then the benefits from these could be even greater.

Figure 16: Millbrook Resort, Queenstown

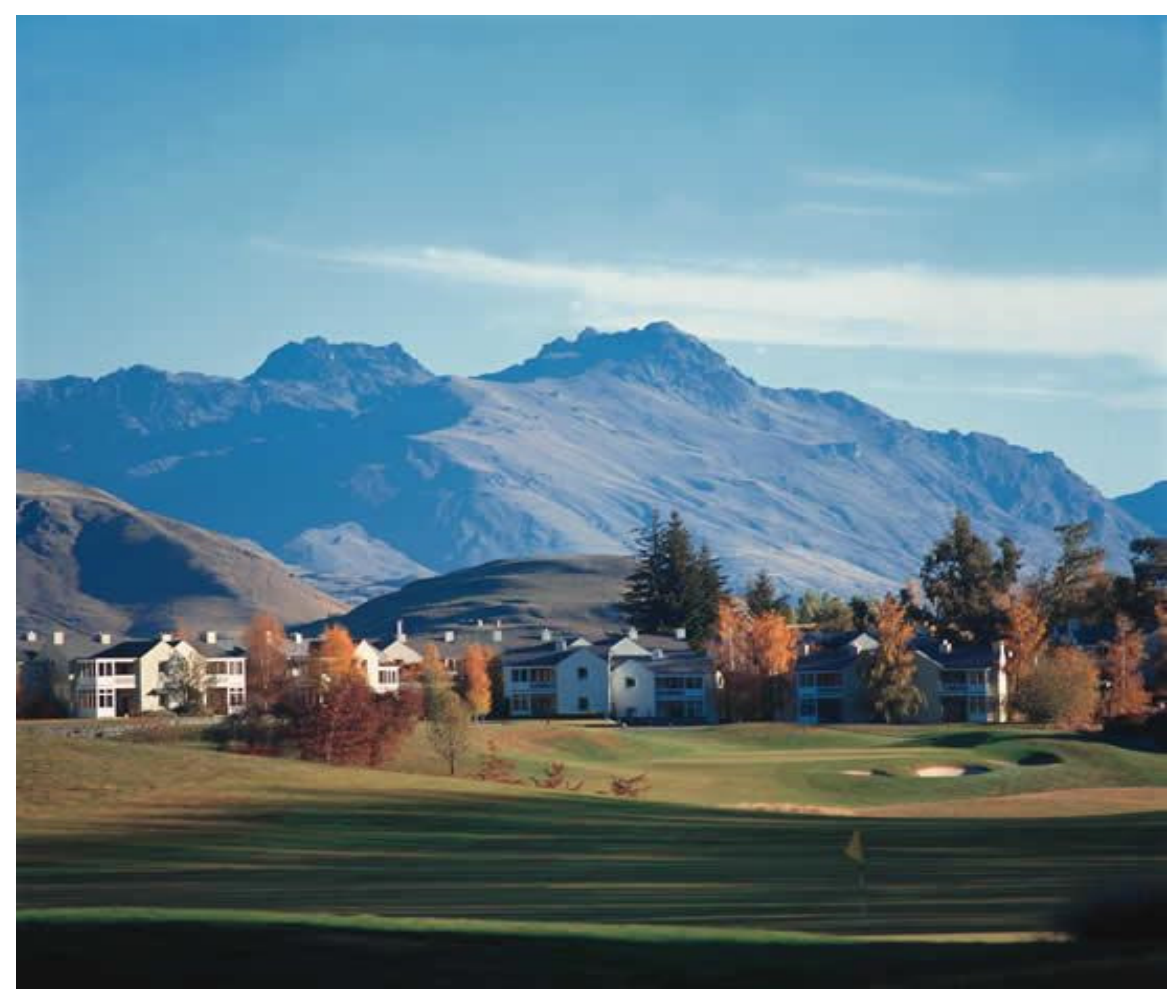

[Source: NZ Golfing, 2009]

In 2002, New Zealand was voted "The Best Undiscovered Golf Destination" by the International Association of Golf Tour Operators (IAGTO), and in 2009 won an 
award for "Golf Destination of the Year 2009" for Australasia and Asia. This means that the importance of golf tourism for New Zealand's economy is likely to have dramatically increased. Golf tourism's importance to New Zealand was noted by the introduction of the "Golf Tourism Cluster" in 2003, an industry wide approach to target international golfers to the country (NZ Golf Tourism Cluster, 2003). The cluster's main objectives are to:

1) Achieve a national quality standard as a recognisable benchmark for international markets.

2) Provide a quality golf experience for first time and repeat visitors to New Zealand.

3) To grow the golf-interested, interactive traveller segment of the inbound tourism market.

4) To position New Zealand as a unique golf destination offering a wide range of course types and terrain.

5) To increase capability of golf tour operators.

6) To secure international media interest for NZ golf (NZ Golf Tourism Cluster, 2003).

New Zealand's Golf Tourism Cluster now goes under the brand name "Best of Golf New Zealand.” The Cluster initially began in 2003 with government funding with an objective to market New Zealand as a desirable tourist destination for international golfers. Membership is primarily made up of a number of the top resort courses in New Zealand, however supporting businesses such as golf tour operators, tourism organisations and accommodation providers are involved at a secondary (or more minor) level (Best of Golf New Zealand, 2009). The Government is no longer involved in funding the Cluster and all funding now comes from members. Information regarding the successes and the shortfalls of the Cluster can be found in the Results section of this thesis.

\subsection{The Cost of Playing Golf in New Zealand}

New Zealand is one of the cheapest countries in the world to play golf. For a non affiliated player (e.g. international visitor or casual golfer) the average cost of a round 
is $\$ 24$, while for an affiliated player (a member of any New Zealand golf course) the average cost is only $\$ 18$. In comparison, the average daily green fee for a course in the United States is \$US 40 (approximately \$NZ 60) (Golf Channel, 2009) while in Japan in 1987, it was difficult to pay less than \$NZ 90 for a round at any course with the average cost being much higher. It is also not uncommon to pay more than $\$ 1$ million for a membership in Japan (NY Times, 2009, Japan Golf, 2009).

For the most part, international golfers will travel to play at higher end golf courses and so the average cost to them will be much greater than \$24. In fact, the average cost for a round at 13 of New Zealand's top courses is relatively high at $\$ 156$ (although at some courses Australian's receive a slightly discounted rate). In comparison, affiliated players to a New Zealand golf course can play at the same courses for almost half these prices in most instances.

Table 7: Average Cost of Playing at New Zealand Golf Courses

\begin{tabular}{|l|r|}
\hline Course & Price \\
\hline Cape Kidnappers & $\$ 350$ \\
\hline Kauri Cliffs & $\$ 350$ \\
\hline Wairakei International & $\$ 200$ \\
\hline Kinloch & $\$ 168$ \\
\hline Carrington & $\$ 135$ \\
\hline Paraparaumu Beach & $\$ 130$ \\
\hline Clearwater & $\$ 130$ \\
\hline Millbrook & $\$ 119$ \\
\hline Terrace Downs & $\$ 103$ \\
\hline Pauanui Lakes & $\$ 100$ \\
\hline Jacks Point & $\$ 90$ \\
\hline Gulf Harbour & $\$ 90$ \\
\hline Formosa & $\$ 65$ \\
\hline Average & $\$ 156$ \\
\hline
\end{tabular}

However, while paying more than $\$ 100$ for a round of golf may seem expensive for the average New Zealand golfer, it is relatively inexpensive given the cost of playing at comparable courses worldwide. For instance, Pebble Beach in the United States costs around \$US 500 per round, equating to approximately \$NZ 700. Also, if international players choose to play at the many courses outside of these, costs are considerably less. 


\subsection{Golf Tourism Data for New Zealand}

This section of the thesis will use the Ministry of Tourism's database to make a quantitative analysis of international golf tourism in New Zealand. Every year, the Ministry conducts an "International Visitor Survey" (IVS) in which approximately 5200 tourists are questioned at Auckland, Wellington or Christchurch international airports upon their departure from New Zealand. The survey aims to provide reliable information on the characteristics, behaviour and expenditure of international visitors. One of the questions in the survey asks respondents about the types of activities they participated in while in the country (Ministry of Tourism, 2009). For this section, only those who responded that they played golf in New Zealand are analysed.

For this survey, it is impossible to distinguish the type of golf tourist who visits. While it is known if a visitor played at least one round of golf, it is not known how many games of golf they played, or whether golf was their main purpose for visiting the country. For the IVS, purpose of travel is limited to the option of; Holiday, Visiting Friends or Family, Business, Education and Other. Golfers could come under any one of these options.

Out of the more than two million visitors to New Zealand each year, the IVS only accounts for approximately 5200 of these. Of these 5200, only a small percentage (around 3\%) participated in golf. Because the sample size is relatively small, data for six years from 2004 to 2009 was aggregated and only the averages over these years will be used in the analysis below.

Between 2004 and 2009, an average of 2.2 million visitors visited New Zealand each year. Of these, approximately $65,000(3 \%)$ played at least one game of golf. The largest market of golf visitors were from Australia, accounting for 34\% of the total. This is followed by the UK (17\%), the US (9\%) and South Korea (9\%) and is shown in the graph below. 


\section{Figure 17: Origin of Golf Tourists to New Zealand}

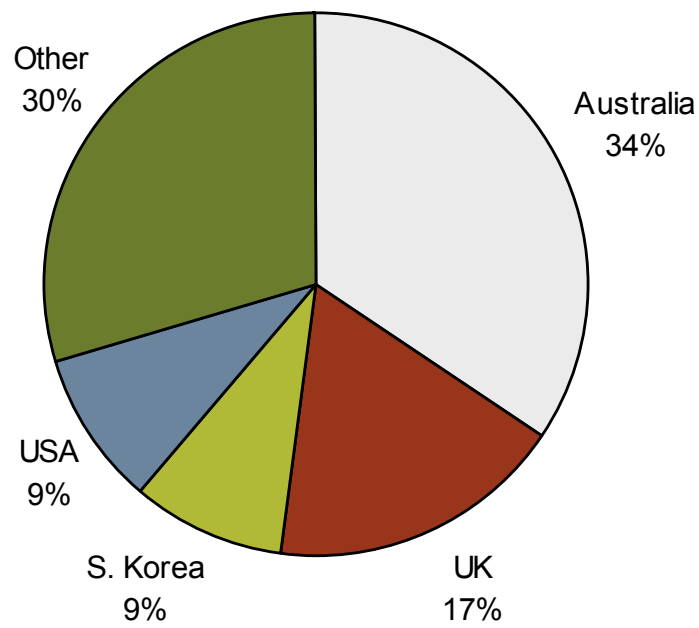

[Source: Ministry of Tourism, 2009]

Worldwide, men make up a much higher percentage of the total number of golfers, and similarly to overseas studies, those visitors who play golf in New Zealand are more likely to be male. $64 \%$ of all golf visitors were male with $36 \%$ female between 2004 and 2009 (see Figure 18).

\section{Figure 18: Gender of Golf Tourists to New Zealand}

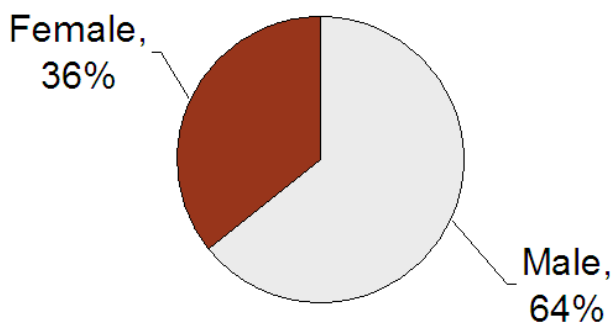

[Source: Ministry of Tourism, 2009]

As for the ages of visitors, there is a relatively even spread amongst all age groups, with those aged between 25-34 and 55-64 each making up about 20\% of the total. All age groups are shown in Figure 19 below, with not a large change between each 
group. This is a surprise as overseas studies have typically shown a higher proportion of golf visitors to be older (45+).

Figure 19: Age of Golf Tourists

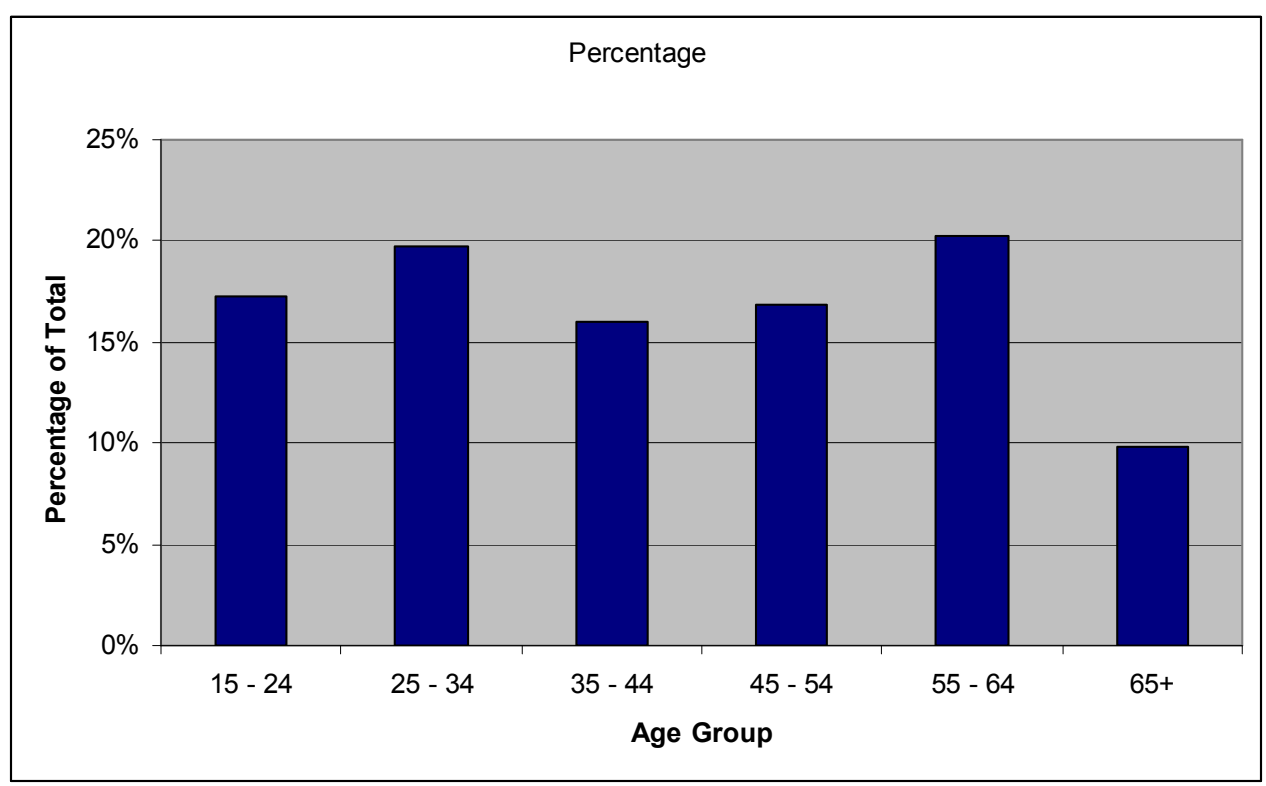

[Source: Ministry of Tourism, 2009]

The next important question that the IVS asks is the expenditure of golf tourists during their stay in New Zealand. It must be noted that the expenditure figures given here are for a person's entire stay in New Zealand, and not just on golfing expenditure which can not be calculated from the survey alone. From 2004, the average tourist spent $\$ 2,703$ during their stay in New Zealand (not including international airfares) while in comparison, the average golf tourist spent $\$ 3,731$. This is a $40 \%$ increase in expenditure over the average tourist, suggesting that those who play golf have a higher income level than average. In total, almost $\$ 250$ million each year is spent by golf visitors and equates for over $4 \%$ of total tourist expenditure in New Zealand (of almost $\$ 6$ billion per year). 
Figure 20: Expenditure by Golf Tourists vs All Tourists (the average tourist)

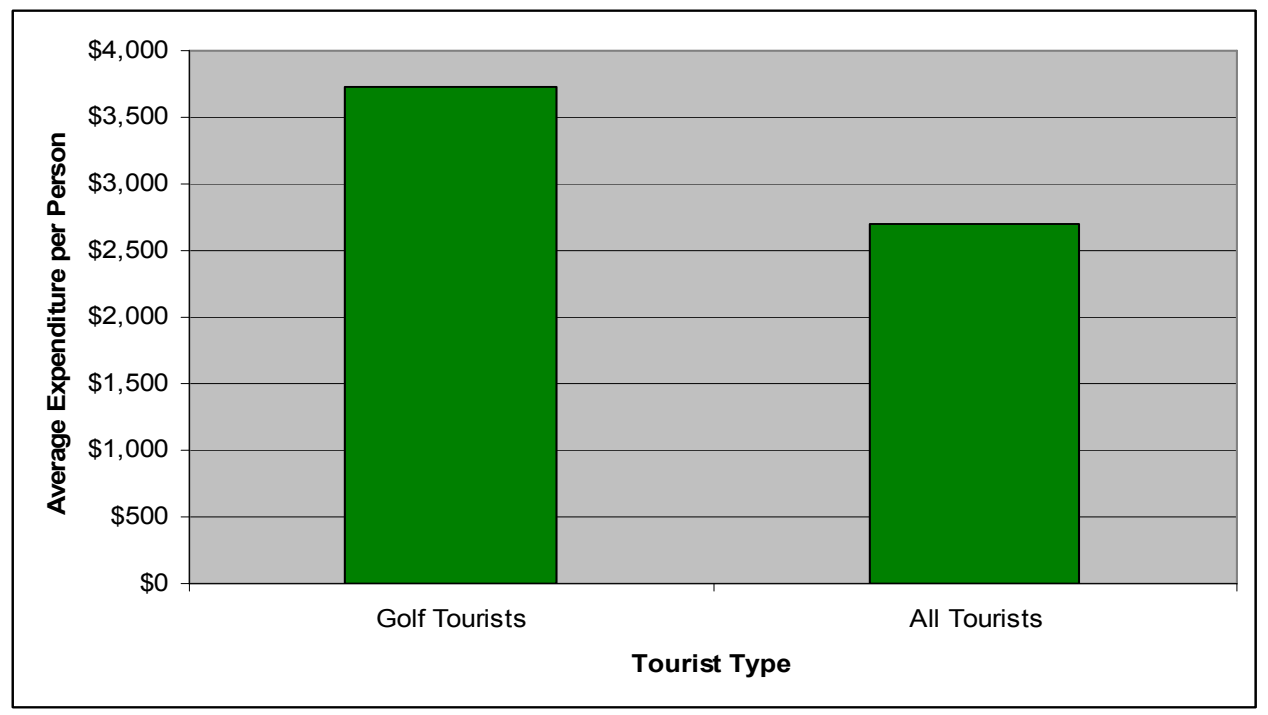

[Source: Ministry of Tourism, 2009]

The six main areas for playing golf in New Zealand were Auckland, Canterbury, Lake Taupo, Queenstown, Northland and Hawkes Bay with these six areas accounting for a combined $50 \%$ of courses played at. Auckland and Canterbury were the top two areas and accounted for $26 \%$ and $13 \%$ of golf rounds respectively.

Figure 21: Where International Visitors Played Golf

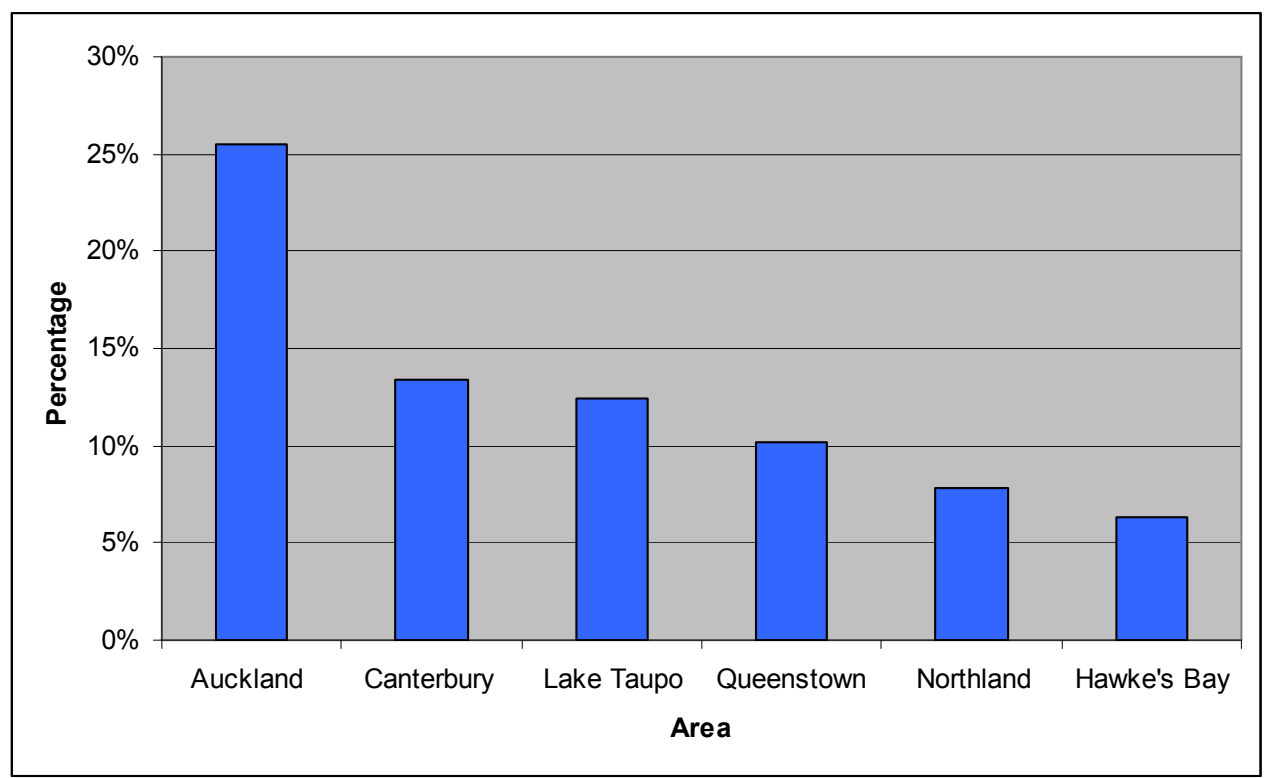

[Source: Ministry of Tourism, 2009] 


\subsection{The Economic Benefits of Golf Tourism in New Zealand}

This section will use the information above to make an estimation into the benefits that international golf visitors bring to New Zealand. In order to make this estimation, Golf 20/20's (2008) definition will be used for comparison and convenience purposes.

\section{The annual number of golf related trips $x$ Average expenditure per trip}

Therefore, from the above figures, this results in a total of $\$ 243$ million being spent by international golfers while in the country.

Table 8: Total spending by international golfers in New Zealand

\begin{tabular}{|l|r|}
\hline Number of Golf Related Trips & 65,000 \\
\hline Average Expenditure & $\$ 3,731$ \\
\hline Total $(\$ \mathrm{~m})$ & $\$ 243$ \\
\hline
\end{tabular}

The direct benefits from visitors who play golf in New Zealand can therefore be estimated at adding \$243 million to New Zealand's economy annually. This is in comparison with an estimated benefit of $\$ 18$ billion to the US economy. As a proportion of the population, these figures are similar for both countries. However, to be included as undertaking golf travel in the United States, a person needed only to travel more than 50 miles and play golf. In comparison, the New Zealand figures only include international visitors; the inclusion of domestic travel would greatly increase total expenditure.

As mentioned in Chapter 4, expenditure by tourists impacts the economy by a total much larger than \$243 million once the indirect and induced effects are taken into account. 
Direct Effects: these are related to the expenditure of golf tourists: this includes their expenditure on golf, accommodation, food and beverages.

Indirect Effects: these effects include the spending and in the industries that tourism supplies good and services to. For example, fertilisers (for the golf course), linen manufacturers (for hotels) and farmers (for stock to feed tourists).

Induced Effects: this is related to the jobs that have been created through golf tourists spending their money here in New Zealand.

[Source: NZIER, 2009]

The simplest way of calculating these effects is to use an economic multiplier, which calculates the inputs and their full value (Schumacher and Spoonley, 2008). The appropriate multiplier can be found using Input-Output tables supplied by Statistics New Zealand. These tables look at the relationships between industries throughout New Zealand and can be used at a regional of national level. Multipliers which take into account both indirect and induced effects are known as Type II multipliers (NZIER, 2009).

A number of economic impact studies have been done in New Zealand in the past. Covec (2005) released an economic impact report on the DHL Lions series (Rugby) on New Zealand. They found that the series bought in $\$ 131$ million on direct spending, and an extra 135.2 million once indirect and induced effects were taken into account (for a total economic benefit of \$266.2 million). NZIER (2009) also released an economic impact report on the New Zealand wine industry. The wine industry is said to add $\$ 1.28$ billion in direct effects, and a total effect of $\$ 3.53$ billion.

As it can be seen, multipliers vary depending on the industry and the region you're in. The total for the economic impact of the Lions series increased by a factor of 2.03 (once all effects were taken into account), while for the wine industry, the total was 
multiplied by a factor of 2.76. Because the Lions series report dealt with tourism spending by sports tourist visitors, the multiplier used there is thought to be a good approximation for golf tourist visitors (as similarly, a large proportion of their spending is on sports costs, accommodation, food and beverages).

Given the direct impact of golf tourism on the New Zealand economy is \$243 million, using a multiplier of 2.03 , the total economic impact of golf tourism is $\$ \mathbf{\$ 4 9 3 . 2 9}$ million. However, it should be noted that there are a number of assumptions underlying the use of multipliers, and therefore this value should be viewed as an "upper-limit result” (NZIER, 2009). 


\section{Chapter 6 \\ Golf Tourism in New Zealand: Interview and Questionnaire Results}

This chapter presents the results and views of those interviewed in the golf industry in New Zealand, combining information obtained from both golf tour operators and golf courses throughout the country. While most of those interviewed wanted to remain anonymous in this thesis, a select few did choose to have their opinions attributed to them.

\subsection{Golf Course Views}

While the Ministry of Tourism's data suggested that 34\% came from Australia, 17\% from the UK and 9\% from the UK, as noted before, it is impossible to distinguish here the type of golf tourist (Type 1, 2 or 3 ) that this information is regarding. It was in the view of the golf course managers that those coming to New Zealand to specifically play golf (Type 3) make up only a small proportion of the total number of tourists who play golf while in the country.

People come here for the New Zealand experience, and if they are golfers, they may just happen to play a round of golf while they are here (anon golf course manager).

A large number of our international green fee players hire golf clubs, which possibly suggests that they are not here to play more than one or two rounds of golf (anon golf course manager).

One other explanation for the many tourists hiring golf clubs could be due to airlines baggage policies. On flights to New Zealand from most countries, only around 20$23 \mathrm{kgs}$ of weight is allowed per person, however they may check in as many items as 
they wish. With a golf bag full of clubs, balls and any other equipment weighing up to $10 \mathrm{kgs}$, this takes up a large proportion of the allowable weight and may discourage bringing them. However, this is not an issue for those travelling to and from North America. From these countries, two items of baggage each weighing up to $23 \mathrm{kgs}$ each is generally allowed.

Table 9: Baggage Allowance when flying into New Zealand

\begin{tabular}{|l|l|l|}
\hline Airline & From North America & From All other Countries \\
\hline Air New Zealand & $2 \times 23 \mathrm{kgs}(46 \mathrm{kgs})$ & $20 \mathrm{kgs}$ total \\
\hline Qantas & $2 \times 23 \mathrm{kgs}(46 \mathrm{kgs})$ & $23 \mathrm{kgs}$ total \\
\hline
\end{tabular}

[Source: Air NZ, 2010, Qantas, 2010]

Estimates from course managers on the percentage of Type 3 golf tourists visiting ranges from $10-50 \%$. The large variation here is likely due to the type of course being visited; the more expensive or 'exclusive' a course is, the more likely a tourist has travelled to specifically play there.

For most of the golf courses interviewed, it is domestic golf tourism that accounts for the most players annually. However, in terms of revenue, all courses admitted that international golf tourism was either 'important' or 'very important.'

Table 10: Visitor Numbers and Origin to Courses in New Zealand

\begin{tabular}{|l|l|l|l|}
\hline & Total Visitors & \multicolumn{1}{|c|}{$\%$ Domestic } & $\%$ International \\
\hline Course One & 22,000 & $87 \%$ & $13 \%$ \\
\hline Course Two & 14,000 & $50 \%$ & $50 \%$ \\
\hline Course Three & 5,000 & $50 \%$ & $50 \%$ \\
\hline Course Four & 15,000 & $70 \%$ & $30 \%$ \\
\hline Course Five & 16,000 & $85 \%$ & $15 \%$ \\
\hline Course Six & 15,000 & $80 \%$ & $20 \%$ \\
\hline
\end{tabular}

Table 10 above shows the total number of visitors to each course, as well as the estimated percentage of domestic and international golf tourists. For most of the 
courses interviewed, international green fee players make up a significant proportion of the total. From the information collected, it is not possible to make any estimation regarding the total number of people who play golf in New Zealand each year. Simply adding up the total of each course will overstate the number as many golfers will play at more than one of these courses while in the country. This would lead to double counting. Also, while interviews were chosen with those courses more likely to have international tourists (resort courses), there are over 400 golf courses in New Zealand that internationals are able to play at. Most of these will attract some tourists each year and how many can not be obtained from these interviews alone. The best estimate as to how many international golfers play in New Zealand each year is the Ministry of Tourism's (2009) survey data of 65,000 people.

\subsection{Golf Course Marketing}

While international golfers were seen to be an important source of revenue, individual golf courses marketing expenditure remains low with most courses spending less than $\$ 40,000$ each year. While one resort spends upwards of $\$ 1$ million annually on marketing, this is predominantly aimed at attracting prospective house buyers. The most common marketing practices for all the courses are through public relations and local advertising. It is common practice for a course to send a delegate to talk to tour agents throughout the world (especially concentrating on those in Australia) as well as visiting a range of conferences.

Most advertising expenditure is low key and limited to the printing of brochures, advertising in local papers, online marketing through their own and other websites and e-mail marketing. There were a number of reasons given by golf course managers as to why they do not spend large quantities of money on marketing their course:

There are so many other golf tourist destinations that New Zealand is just a 'grain of salt' in the market and so marketing to overseas visitors is just a waste of time and money. Instead we concentrate on the domestic market and we find that email marketing is the best and most cost-efficient way to promote the course as it is essentially free. For 
instance, we e-mailed out mid week winter specials and had 160 people come to course from emails alone in June (anon, golf course manager).

While we do spend a small amount on international marketing, it is very difficult for us to measure its effectiveness. So spending more would just be a gamble for us (anon, golf course manager).

It is unlikely that [overseas] tourists are going to come all the way over solely just to play at our course. Most will try to play at a number of New Zealand's top courses and so unless all courses can fairly market New Zealand golf as a whole, it is not in our best interests to market to this sector (anon, golf course manager).

The last quote can be termed in economics as the 'free-rider problem.' If one golf course spends a large quantity of money marketing themselves, this will cause more golfers to come and play at that course, as well as other courses throughout New Zealand. Therefore courses that do not pay are able to benefit from another courses marketing and it is impossible to exclude any course from doing so. The only other marketing practice used by New Zealand's top courses is through the Golf Tourism Cluster. This goes someway in helping to reduce the free-rider problem.

\subsection{Golf Tourism Cluster}

As mentioned in Chapter 3, the Golf Tourism Cluster began in 2003, and now runs under the brand name "Best of Golf New Zealand." Since its conception in 2003, the Cluster has been a mixed success. During this time, all major resort style courses have at one time been a member of the Cluster however, support has not been consistent. Many courses have gone in and out of the Cluster, reducing its effectiveness. Membership for the Cluster currently stands at only six members, although a number of associate members also exist (e.g. tour operators).

Geoff Burns, the manager of the Cluster, believes that New Zealand has a significant capacity for golf and has the ability to meet the needs of a number of markets (especially the Australian market). It is his view that there needs to be a better focus for market development. For example, as tour operators only make up a small 
proportion of the market, there needs to exist online tools for tourists to design their own itineraries. Also there needs to be a push to Asia, and especially China, as a large and potential future market. However, while work has been done by the Cluster to promote New Zealand as a golf destination, it has been on a small scale due to a lack of funding. Achievements of the Cluster so far include; a database of tour operators and trade media who are communicated with through different channels, advertising in golf magazines and around 5000 pamphlets promoting New Zealand golf are given out each year at trade shows (Burns, 2009).

Figure 22: Cover page of the Pamphlet created by the Golf Tourism Cluster

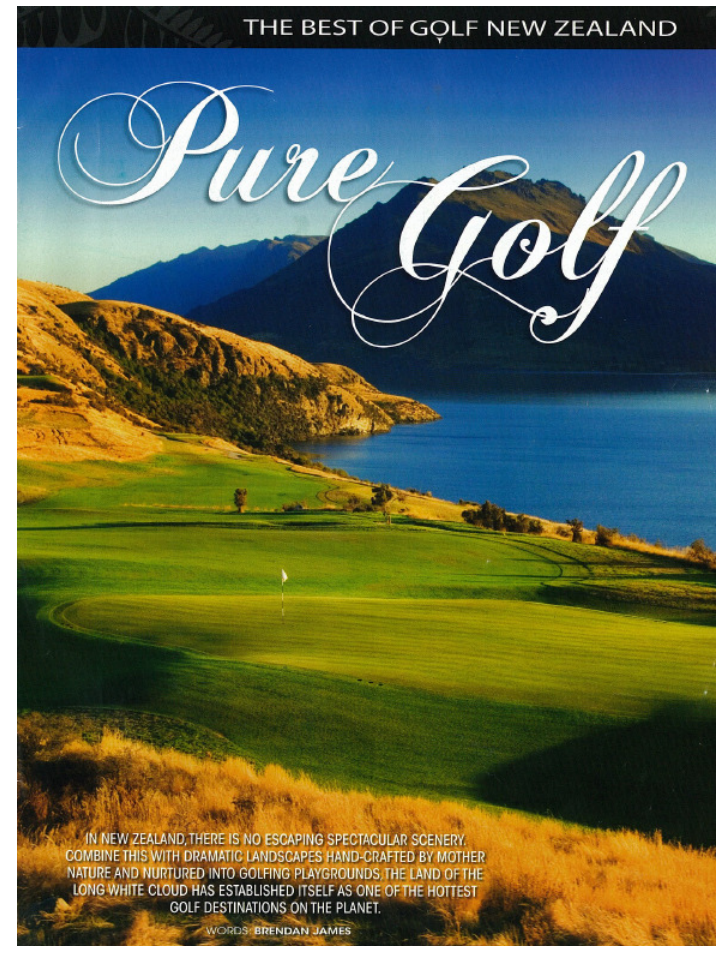

[Source: Best of Golf NZ, 2009]

While the government originally put forward funding through New Zealand Trade and Enterprise, the Cluster is now fully funded by its members with no government involvement. Departments such as Tourism New Zealand have been inconsistent with their support and it in Geoff's view that the only way for the Cluster to reach its full potential is for funding to dramatically increase. As support from many of New Zealand's top courses has been indifferent over the past few years, this extra money 
will need to come directly as an investment from the government (Geoff Burns, 2009).

Of the six courses interviewed for this research, three are current members of the Cluster. There are a number of reasons given by each member course as to why they continue to remain a part of the Cluster and these are given below;

While it is not a necessity, it is a good place to share ideas, costs minimal money and it is good to have all the resources in one place which is important (anon, golf course manager).

For us, it [the Golf Tourism Cluster] is essentially a marketing body and is like a clone of the Irish Tourism Board version. It is only in its early days but it does help to try and showcase the top courses in New Zealand (anon, golf course manager).

The Cluster is essentially another form of marketing for us. Our marketing in mainly New Zealand orientated at present and so being part of the Cluster helps to promote New Zealand golf and ourselves to the international market (anon, golf course manager).

Of the remaining courses who are not part of the Cluster, the main problems these courses had was a perceived lack of benefits to them, the cost of joining and the lack of international visitors visiting the course.

Our main aim is to get as many New Zealanders to become members or play at our course rather than trying to get foreigners. For that reason signing up [to the Cluster] is probably a waste of time and money for us (anon golf course manager).

While I think that the Golf Tourism Cluster is good idea in theory, I am unsure as to how effective it has been. So we prefer to use the money to try and market ourselves individually instead (anon golf course manager). 
Overall it can be seen that the Golf Tourism Cluster is perceived by most in the industry as being beneficial to New Zealand golf. However, because of its overall lack of funds, the inability to measure its effectiveness and the small size of the Cluster, it has not been as effective as it could be.

\subsection{Country of Origin}

Both golf course managers and golf tour operators were asked about the composition of their international visitors and clients. All responded that Australia was their largest target market, followed by the US and the UK. Although numbers vary between courses and tour operators, the graph below shows the average proportion of visitors in terms of their country of origin.

Figure 23: Origin of Golf Visitors to New Zealand

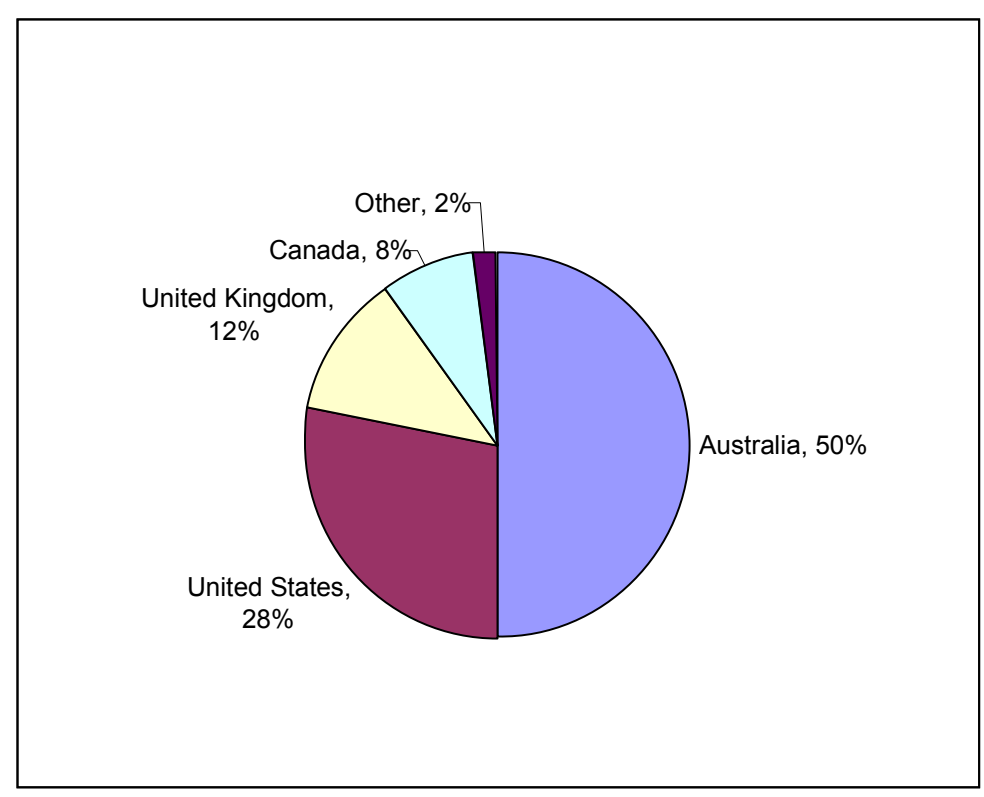

It is no surprise that New Zealand's closest neighbour, Australia, brings the largest number of golf tourists into the country. In the year ending August 2009, a total of 2,410,471 internationals arrived into New Zealand. Of these, just over 1 million $(42 \%)$ were from Australia. While this number is similar to the estimated $50 \%$ of international golf visitors, the $28 \%$ value for the US is much higher than the percentage of general tourist arrivals, which only account for $8 \%$ of total tourist 
numbers to New Zealand (Ministry of Tourism, 2009). All countries differences are shown in the table below.

Table 11: The Percentage of Golf Tourists vs Total Tourist Arrivals

\begin{tabular}{|l|rr|r|}
\hline Country & Golf Tourist \% & & General Tourist \% \\
\hline Australia & & $50 \%$ & $42 \%$ \\
United States & & $28 \%$ & $8 \%$ \\
United Kingdom & & $12 \%$ & $11 \%$ \\
Canada & & $8 \%$ & $2 \%$ \\
\hline
\end{tabular}

For the US, the large difference here is likely due to the high percentage (50\%) of the world's golf players and courses being located there. It would therefore be expected that a higher percentage of golf tourists to New Zealand would originate from the US.

The most notable omission seen here is the lack of golfers from the Asian region, especially Japan and South Korea. The figures above were the result of information obtained from golf tour operators in New Zealand. All tour operator websites and guided tours are given in English. Therefore language barriers may result in those from non-English speaking countries booking through tour operators in their own country, or to travel independently. One golf course estimated the number of Asian visitors to their course "to be in the vicinity of 20\%", with the Ministry of Tourism's data suggesting that $19 \%$ of golfers are from this region. It is important to note that visitors from Asia are important for golf tourism in New Zealand. It is unfortunate that because of difficulties obtaining information from this market, it was outside the scope of this research.

\subsection{Golf Tours in New Zealand}

This section of the thesis will incorporate information gathered from golf tour operators and the questionnaires returned by their clients.

A thorough Internet search revealed more than 35 operators who organise golf tours throughout New Zealand. Many are specialised golf tour operators, who only organise golf related tours, while others organise 'whole package tours' where golf is 
just one of the many types of tours offered (i.e. for one tour operator, $10 \%$ of their business was from golf tours, with the rest from other sports or general sightseeing).

For all tour operators interviewed, all began undertaking golf tours after the year 2000 , with five out of the 12 starting after 2005. All operators were asked why they decided to start organising golf tours, with the most common answer being a perceived gap in the market;

We started organising golf tours about six years ago because we felt there was a lack of New Zealand based companies offering golf tours in New Zealand (anon, tour operator).

Golf has always been a part of my life, playing throughout school and I also worked at Millbrook for a time. I saw an opening in the market for arranging golf tours in Queenstown [...] and I began organising these in December 2007 (Tim Kershaw, tour operator).

The sudden rise in the number of golf tour operators is predominantly due to the rise of the Internet. When asked about the marketing strategies used, for all operators, their website was their number one marketing tool.

The only real cost to us was getting our website created in the first place [...] ongoing costs are relatively small and so starting this company did not involve a high level a risk (Rauru Walker, tour operator).

The main other marketing methods used by tour operators are links from other websites, the attendance of trade shows and advertisements in selected golf publications. Only three golf tour operators were members of the IAGTO. There is no large scale investment in marketing by any operator. Instead, many are reliant on word of mouth and Internet search engines to increase their client base. The website of each tour operator is therefore the most important tool in attracting prospective clients. Examples of these can be seen in Figure 24 below. 
Figure 24: Golf Tour Operator Websites
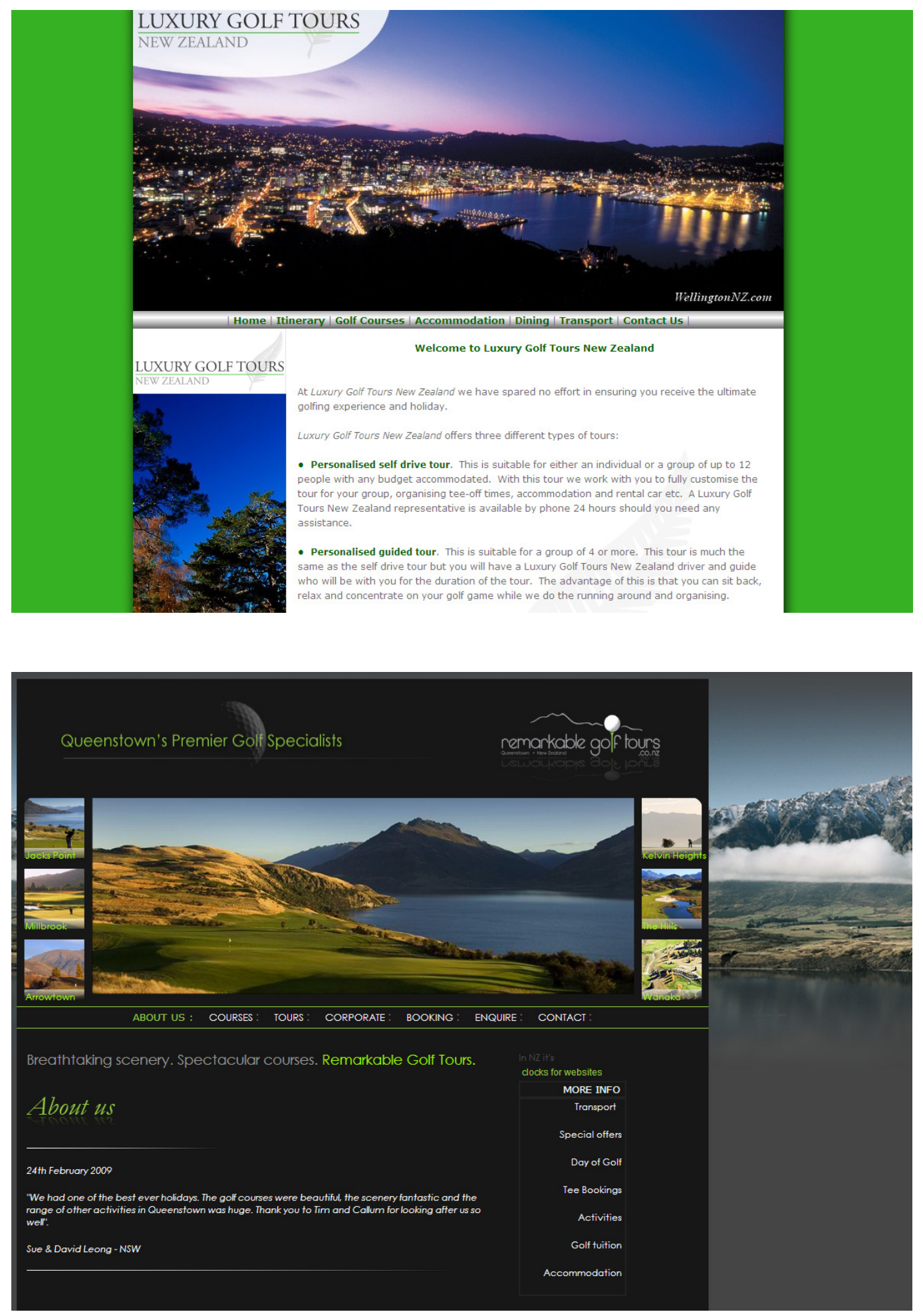

[Source: Luxury Golf Tours, 2009; Remarkable Golf Tours; 2009] 
Golf tours are organised in two ways; self drive, where the tour operator will organise and book every detail of the trip, however the person or people involved drive themselves to and from each destination. The second are fully escorted tours where a tour guide accompanies the tour, driving the vehicle and organising any other details that are required. These can either be arranged privately for any day the client wishes to travel, or else publicly where a pre organised itinerary is arranged and starts on a specified date. Five out of the 12 tour operators interviewed offer such tours. However, these types of tours make up a relatively small share of the market, with approximately $85 \%$ of tourists opting for self drive tours.

While on either type of tour, the average golf tour lasted for 14 days, and during this time an average of eight golf courses were played at in a number of areas throughout New Zealand. This is much longer than the average tour length in the EMA region, where the average golf holiday lasted for only one week however, golf was played on most days.

From the golfer's questionnaire, the most popular reason given to visit New Zealand was the quality of golf courses, followed by 'as a recommendation' from previous visitors. While golf is seen as being inexpensive in New Zealand, the price of golf courses was not a major influence in a tourist's decision to travel here. This is likely due to international visitors paying more on green fees than New Zealanders and that golf green fees make up only a small proportion of total spending. Flights and accommodation are the most significant costs and so their price is likely more important than the cost of golf. New Zealand's scenic beauty and general sightseeing opportunities were also common answers given as to why they chose to visit New Zealand.

For those considering alternative golf destinations, Australia was New Zealand's biggest competition, with Hawaii, Spain, Scotland and South Africa all commonly mentioned. For those from the US, Australia and Hawaii were the two alternative destinations primarily given. Those from the northern hemisphere tend to travel during their winter to warmer climates in the south. A number of US golfers had already previously visited Australia and other international destinations and tended to 
be well travelled. The main competition from Australian visitors was Australia itself through inter-state travel (e.g. New South Wales to Queensland).

The questionnaire also asked respondents what were the most and least enjoyable aspects of their trip to New Zealand. The positives strongly outweighed the negatives and the table below shows the most common responses for each.

Table 12: Positive and Negative Attributes of Golf Tourist's time in New Zealand

\begin{tabular}{|l|l|}
\hline \multicolumn{1}{|c|}{ Positives } & \multicolumn{1}{|c|}{ Negatives } \\
\hline Great golf courses & Travel times \\
Scenery & The weather \\
Value for money & \\
Friendly people & \\
Food (wining and dining) & \\
\hline
\end{tabular}

Visitors seemed to not only enjoy their golf, but also their entire New Zealand experience. As golf only takes up a few hours of the day, visitors enjoyed their time seeing the sights and eating out during the evenings. The two main problems were too much travel and the weather. Given that New Zealand's best golf courses are spread throughout the country, travelling between them (especially by road) can take up a significant part of the day. In addition to this, many arrive from long haul countries where more than 12 hours has been spent flying to New Zealand. Many respondents also found New Zealand to be too cold with not enough sun, especially those in the older age brackets (45+). However, part of this can be explained by the timing of the questionnaire. Those who responded to the questionnaire visited between September and December 2009, when it is colder and the weather is much less settled. Had respondents visited during the January to March period, weather would likely have been less of an issue.

There are a number of main ways that visitor's originally heard or found out about playing golf in New Zealand. The most common way was through a recommendation (through friends or family), followed by golf magazines and Internet searches. This is 
consistent with most golf tour operators who found that word of mouth and their webpage were the most common sources in attracting their clients. However, from Figure 25 below, it is not necessarily how the visitor found out about playing golf in New Zealand, but travel to New Zealand in general. For instance, New Zealand could have been recommended by others for its sightseeing opportunities, with golf being found out through another avenue (e.g. Internet searches).

Figure 25: How the visitor first heard about travel to New Zealand

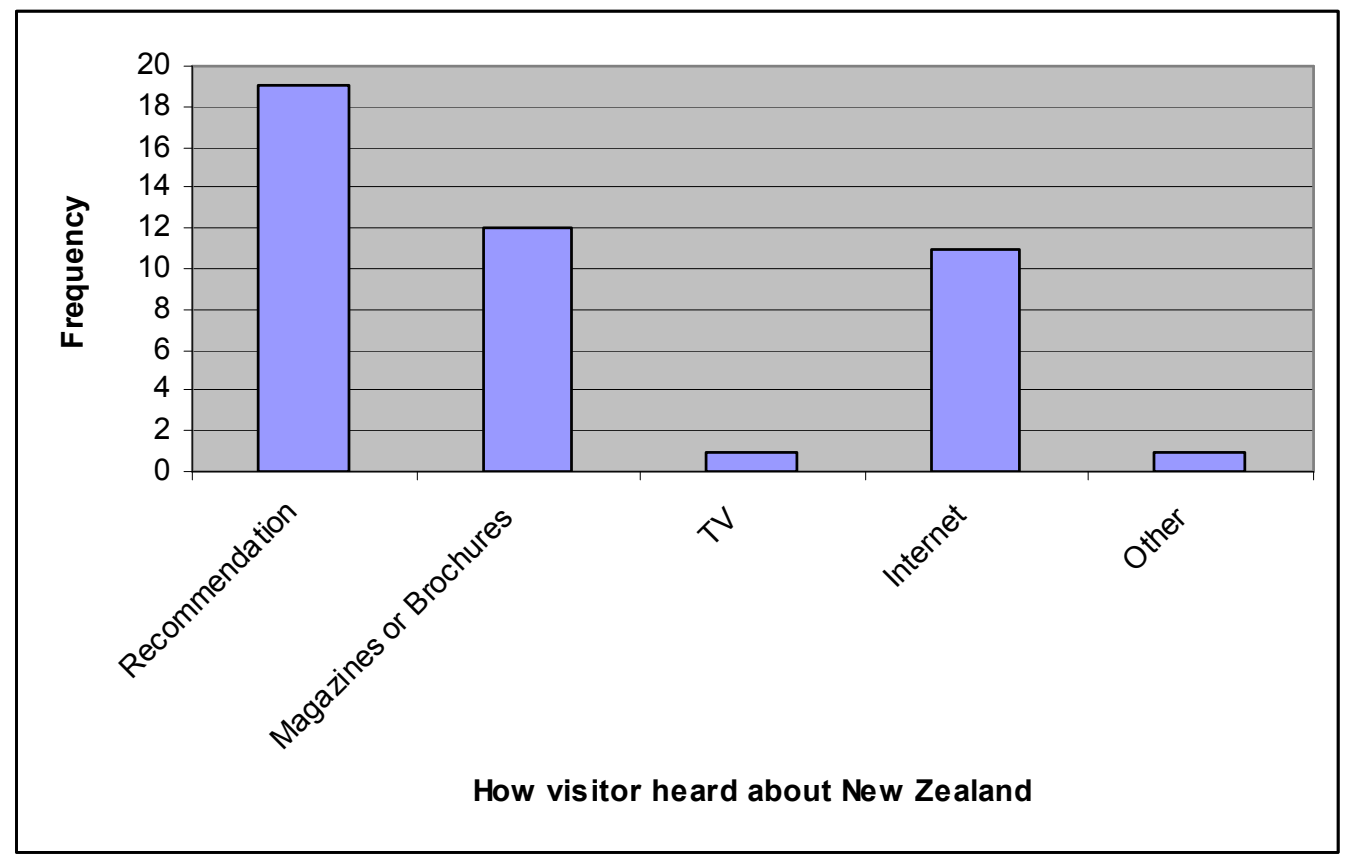

When respondents were asked if they would consider returning to New Zealand to play golf, most answered 'Maybe'. Those from further a field (US, Canada and the UK) were more likely to be in the Maybe or No categories, while Australian's were those most likely to return. Given the distance travelled by many, it is no surprise that a return visit may not be made. As one respondent from the US said;

I had a great time here, however it was a trip of a life time and I doubt l'd ever return, at least not to play golf (anon, questionnaire respondent). 
It is therefore the distance travelled that is the largest barrier stopping return visitors. The graph below shows the numbers who would / would not consider retuning to New Zealand to play golf in the future.

Figure 26: Those who would consider returning to New Zealand to play golf

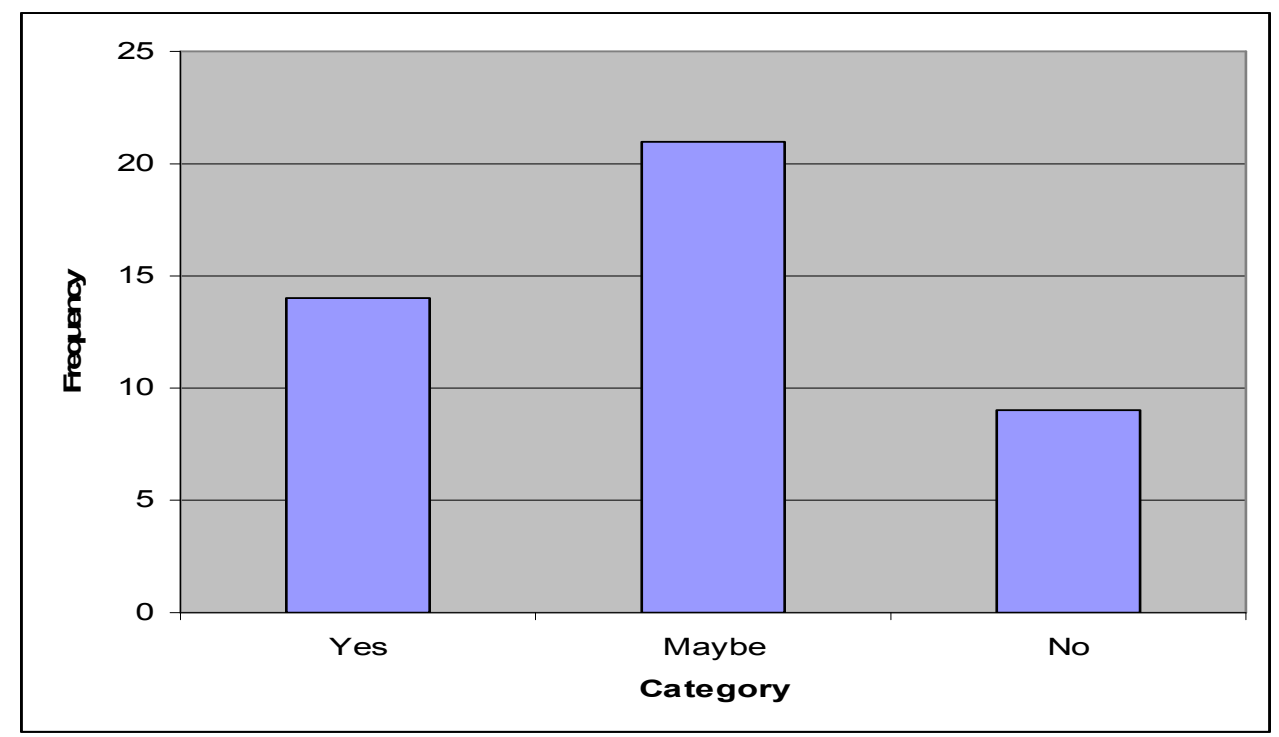

\subsection{Demographics and Spending Habits}

The next question golf tour operators were asked was about the demographics of their clients. Overseas studies have shown golf tourists to be older males and the case is no different for New Zealand. The average age of a New Zealand golf tourist is about 55 years old with $67 \%$ of tourists being male. For Australia and South Africa, the average age was found to be 42 and 45 respectively.

In addition to this, the graph below shows the age brackets of those who completed the golfer's questionnaire. These results show a much older demographic then found using the Ministry of Tourism's data in Chapter 5. 
Figure 27: Ages of Golf Tourists taking Tours

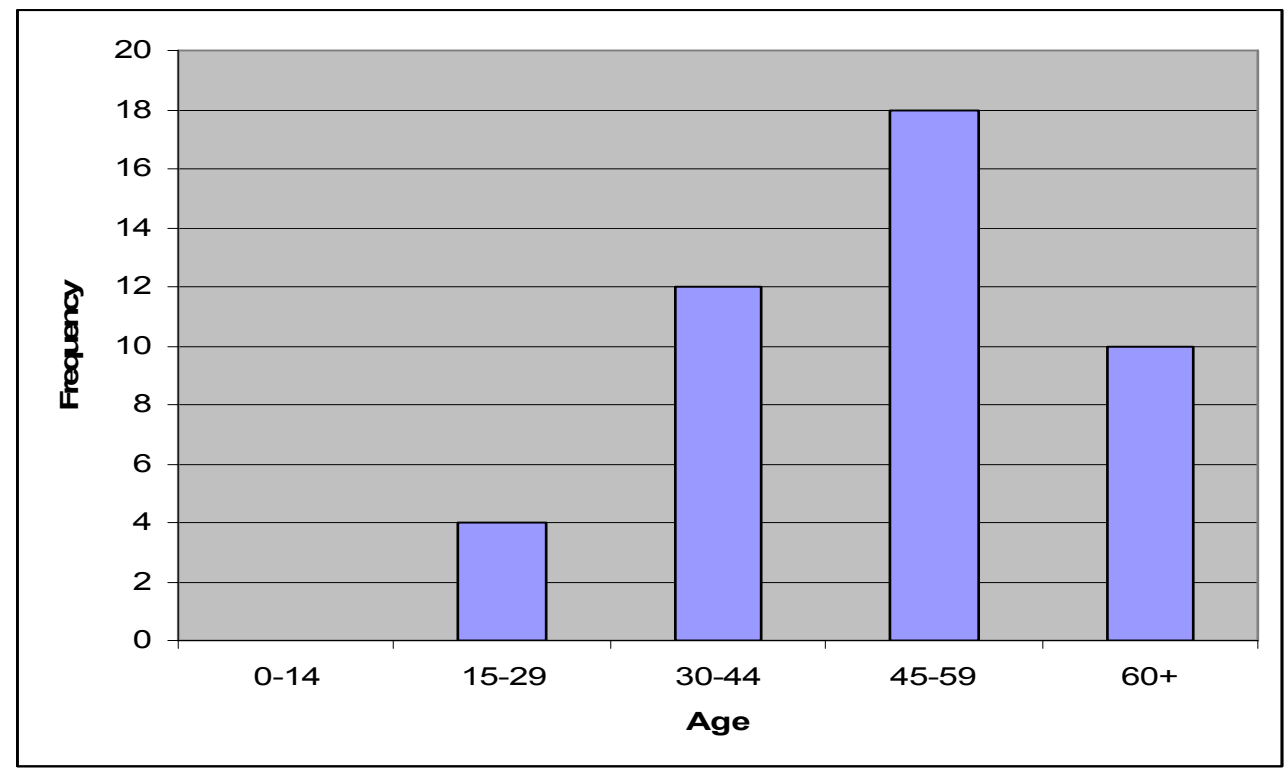

New Zealand has the oldest golf tourists out of all the destinations listed above, however the methodology used in this research may explain this. Older travellers may be more likely to book through a travel agency whereas it is possible those who are younger are more likely to travel alone (Fully Independent Travellers, or FITs). Thus while the information from golf tour operators successfully captures many of the Type 3 golf tourists the thesis is looking for, some differences may arise because of this. Data from the Ministry of Tourism's showed a more even spread through all age groups, suggesting a lower average age. Again the methodology is important; Type 1 and Type 2 golf tourists are likely to be younger than Type 3 tourists, and there inclusion will likely lower the average age (such as is the case for Australia).

While men make up approximately $67 \%$ of golf tours, four tour operators claimed to have a 50-50 split between men and woman. This is due to many golfers travelling with their partners. In some cases, the female partner does not even partake in golf while on tour, and instead other activities are arranged. It is the small, self drive groups that tend to have a more even split between men and women. Larger groups, especially fully escorted tours tended to have a higher proportion of men. 
Not only are golf tourists to New Zealand older and male, they are also much wealthier than the average tourist. Total expenditure on most golf tours far exceeds normal tourist spending. During their stay in New Zealand, the average tourist will stay for 14 days, spending a total of approximately \$NZ 5000 on a tour. The cost of a tour is dependant on a number of factors, namely the length of the tour, the distance travelled and the level of luxury each tourist chooses. In most cases, golf tour operators did not book their clients international flights, but took care of everything else. Prices typically include all transport, accommodation, food (breakfast, lunch and dinner) and golf green fees.

A simple, week long tour can cost as little as $\$ 1500$ per person, however those who choose the more luxurious option can pay as much as $\$ 13,000$ per week. This includes staying at New Zealand's top accommodation, such as Huka Lodge near Taupo, and the lodges at Cape Kidnappers and Kauri Cliffs. During the summer months, one night at Huka Lodge costs $\$ 1375$ per person per night for a double room.

\section{Figure 28: Huka Lodge - The luxury sought by many US golf tourists}

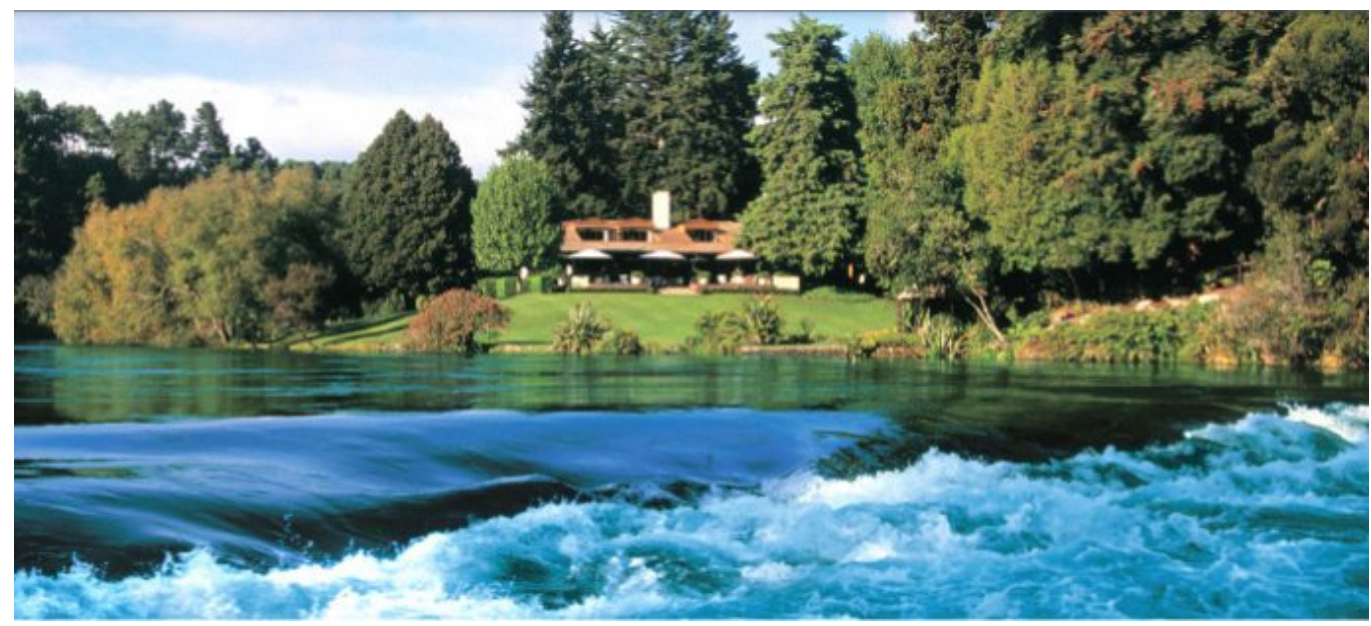

[Source: Hukalodge, 2009] 
The lodges at Kauri Cliffs and Cape Kidnappers each cost approximately $\$ 1000$ per person per night. It is not uncommon for people to enquire about staying at all three while on tour.

We get a number of people, especially those from the US, wishing to stay at the best possible accommodation in New Zealand. While some do find the price a little steep, there are a select few who do decide to stay in places like Huka Lodge and the Lodges at Kauri Cliffs and Cape Kidnappers. Otherwise, we will still generally put people up in other 5 star accommodation nearby (anon, tour operator).

Higher incomes have led to golf tourists staying at higher quality accommodation. For all tour operators, the 4 and 5 star accommodation options were the most popular choices. Those requesting 3 star accommodation make up a very small percentage of the total (less than 5\%), with any lower quality options being non-existent.

Spending by golf tourists is due to their high level of earnings, with the golfer's questionnaire finding the most common earning bracket to be between $\$ 60,000$ and $\$ 89,000$ for all currency types. Because tourists visit from a number of countries, the currencies used in each country differs. $\$ 60,000$ earned in $\$ U S$ was worth $\$ 67,000$ Australian dollars and only $£ 37,000$ British Pounds at time of writing These differences are not shown in Figure 29 below however; it still shows the overall impression that golf tourists are higher earners as all currency types given in the questionnaire are stronger than the New Zealand Dollar. 
Figure 29: Annual Earnings by Golf Tourists

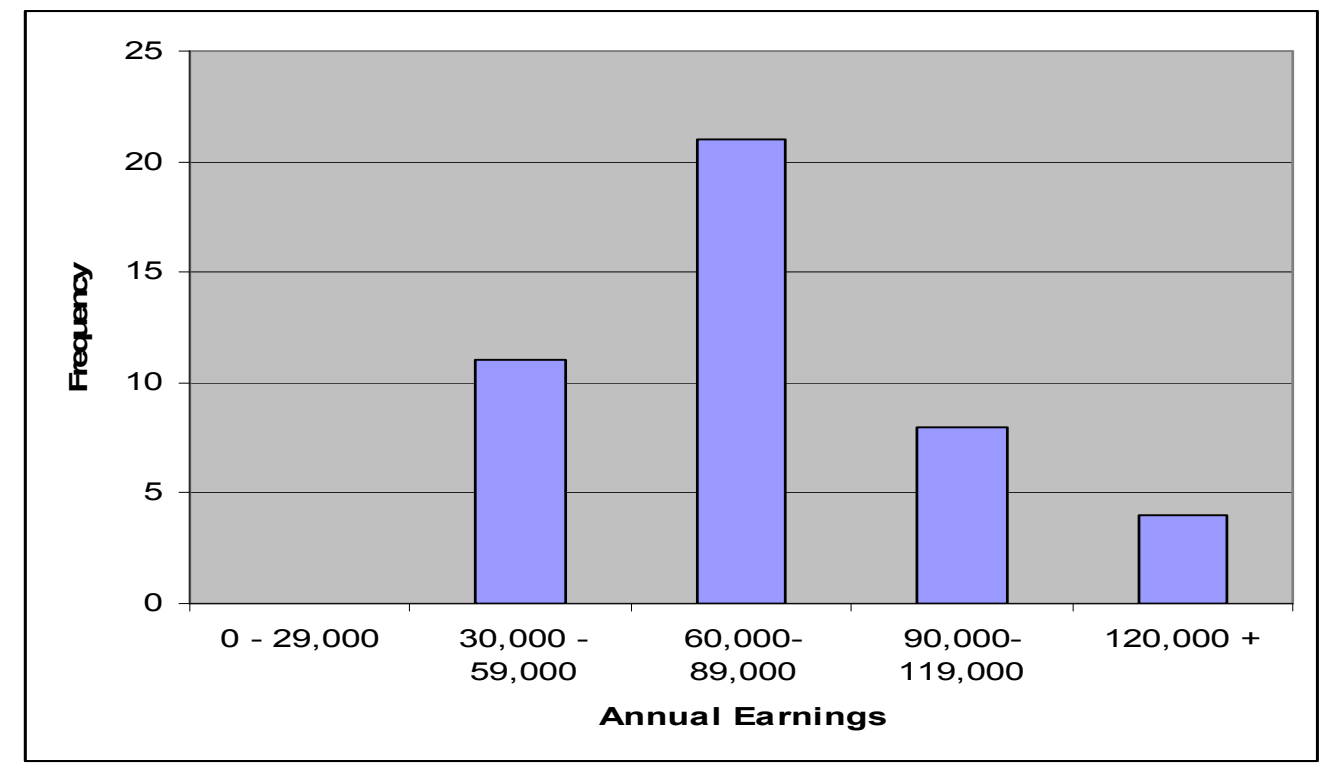

For specific countries, those from Australia were likely to earn in the middle to lower brackets, those from the UK and Canada in the middle bracket, while golf tourists originating from the US in the middle to higher income brackets.

\subsection{Where Golf Tourists Visit}

All tour operators were asked to list the courses that their clients typically play at while in the country, while the golfer's questionnaire also asked tourists to list the courses they played at. It is no surprise that the resort courses were the most popular, although a number of other courses were used, especially in the areas surrounding resort courses. The four core areas visited were Auckland, the central North Island, Christchurch and Queenstown. 
Figure 30: Locations of popular courses visited by golf tourists

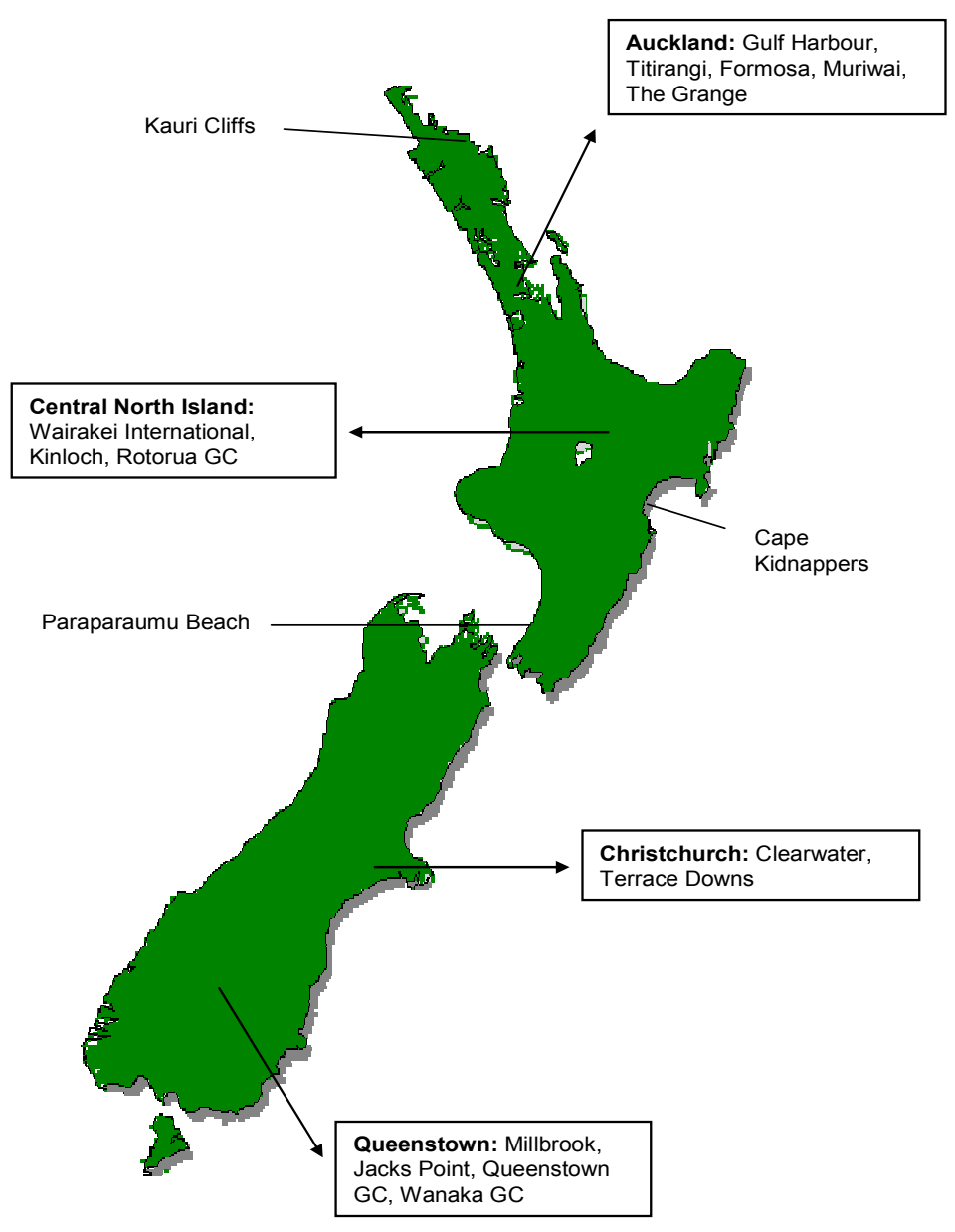

The map above shows the most common courses that tour operators listed as sending their clients to. The most popular destinations of Auckland, the central North Island, Christchurch and Queenstown are those areas with a high density of quality courses all within a short distance of one another.

I concentrate on organising and hosting golf tours in the Queenstown area, rather than New Zealand as a whole [which many other operators do]. This area is great in that we have so many great golf courses all so close to each other (Tim Kershaw, tour operator).

Three other courses commonly visited outside of these four areas are Kauri Cliffs, Cape Kidnappers and Paraparaumu Beach. This is due to all three courses having the 
prestige of being, or being previously ranked in the 'Top 100 golf courses in the world.' It is a common occurrence for those on luxury tours to be flown directly to these courses by helicopter, minimising travel time. This is because travel time is seen by tour operators as being a major obstacle to the industries growth. In a typical two week tour, it is very difficult for tourists to visit all courses listed in the map above. What has become common is for a golf tourist to either do a North or South Island tour, visiting two out of the four core golfing areas in New Zealand.

\subsection{The Seasonality of Golf Tourism}

In some countries such as Canada and Scotland, adverse weather conditions and snow falls result in many courses being closed during the winter months. However, in New Zealand, golf can be played all year round with courses only being closed on the odd day due to rain or snow (see weather comparisons in Chapter 2). But while these courses are open year round, international golf tourists tend not to visit in high numbers during the winter months. For most tour operators and courses, the 'golf season' starts in October, and goes through until April with February being the busiest month. During an interview, one tour operator was able to give information regarding the total number of tourists taken in 2008 on a monthly basis. As it can be seen, the winter months accounted for less than $6 \%$ of total tourist numbers for this operator.

Figure 31: The Seasonality of Golf Tourism

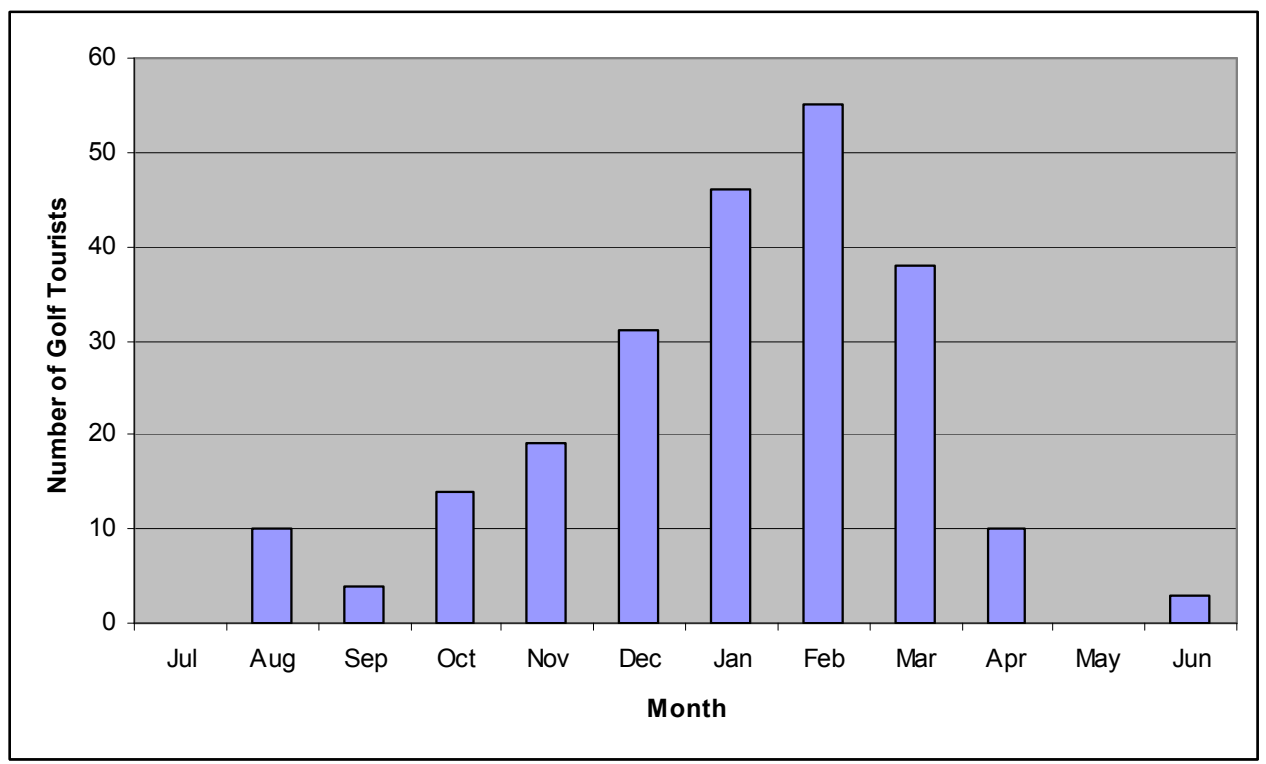


While the above graph only represents the figures of one tour operator, the general pattern shown remains the general consensus among all travel operators. However, this is not to say that international visitors do not play any golf during the winter. For some of the golf courses interviewed, while winter was their low season, the green fees from international visitors will still be an important source of revenue. This is especially true of golf courses close to ski fields, such as Terrace Downs.

Our busy season is between January and April when the weather is more settled. During this time there tend to be a large number of visitors going on a 'golf trail' round the South Island. But we still do get international golfers during the ski season, especially Australians who come over to ski and will play golf while they are here. Also, there is a positive correlation between how good the ski season is at Mt Hutt, and how many golfers come to play here. Although the correlation is possibly stronger for the previous ski season. If it was good last year then more people tend to come the year after (Nigel Davis, golf course manager).

\section{Figure 32: The $7^{\text {th }}$ Hole at Terrace Downs overlooking Mt Hutt}

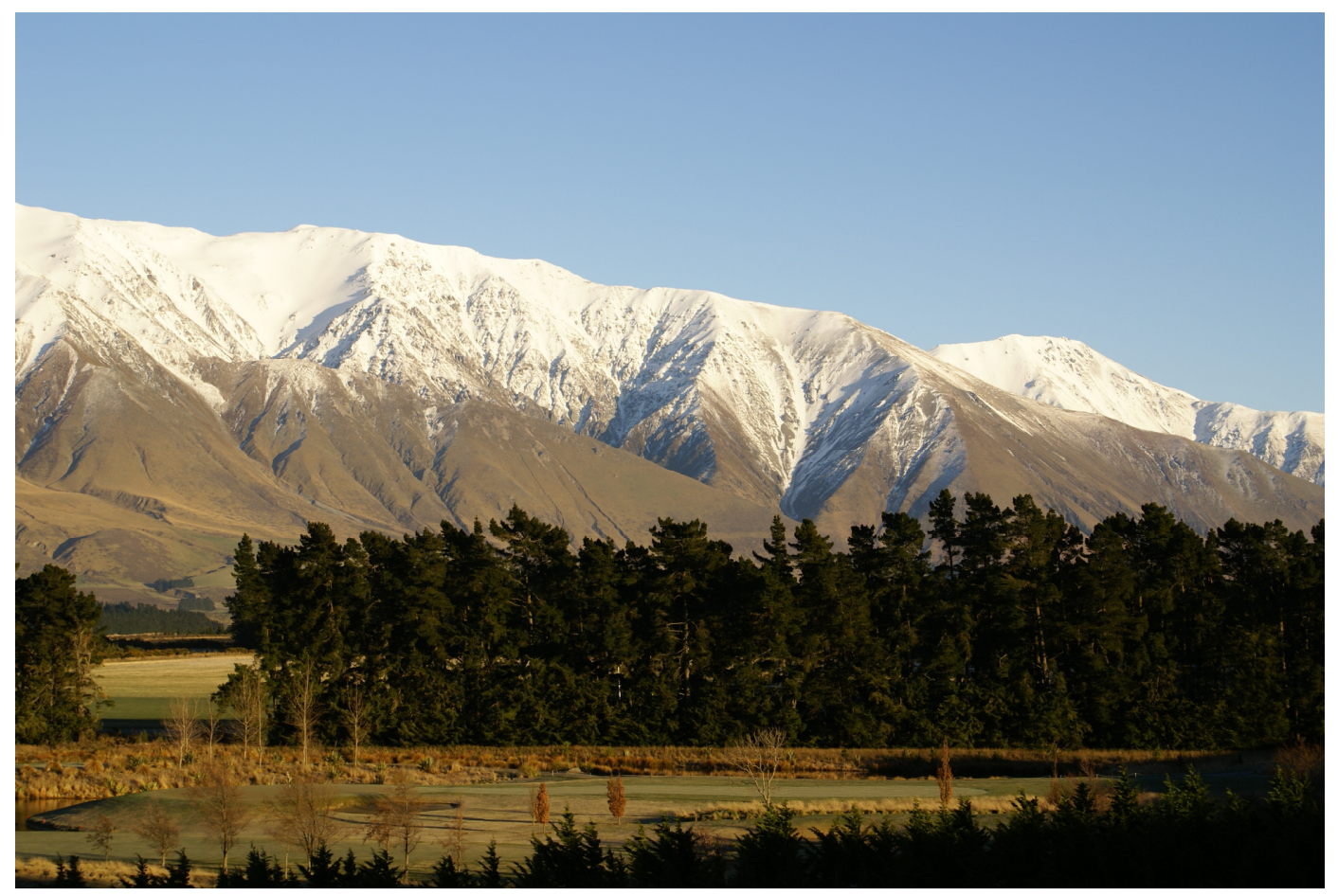


With a number of ski fields in close proximity to a number of New Zealand's top South Island golf courses (Terrace Downs, Clearwater, Millbrook, Jacks Point, Queenstown Golf Club), this will help drive golf tourism in the winter months. However, again these will likely be Type 1 golf tourists as according to tour operators, there is a lack of tours taken during the winter months.

I can not really recall anyone on our tours who has requested to go skiing as well as playing golf. I think due to many of our clients being the older type, they have no interest in the cold and therefore only seem to come here during the warmer and sunnier months (anon, tour operator).

\subsection{Golfing Characteristics}

Golfers who travel to New Zealand on golf tours can mostly be classified as 'avid golfers'. An avid golfer is someone who plays 25+ rounds of golf each year, and most visitors who participated in the questionnaire fit into this category. Figure 33 shows how the majority of visitors tend to play more than 20 rounds of golf each year.

Figure 33: Total number of rounds of golf per year by Golf Tourists

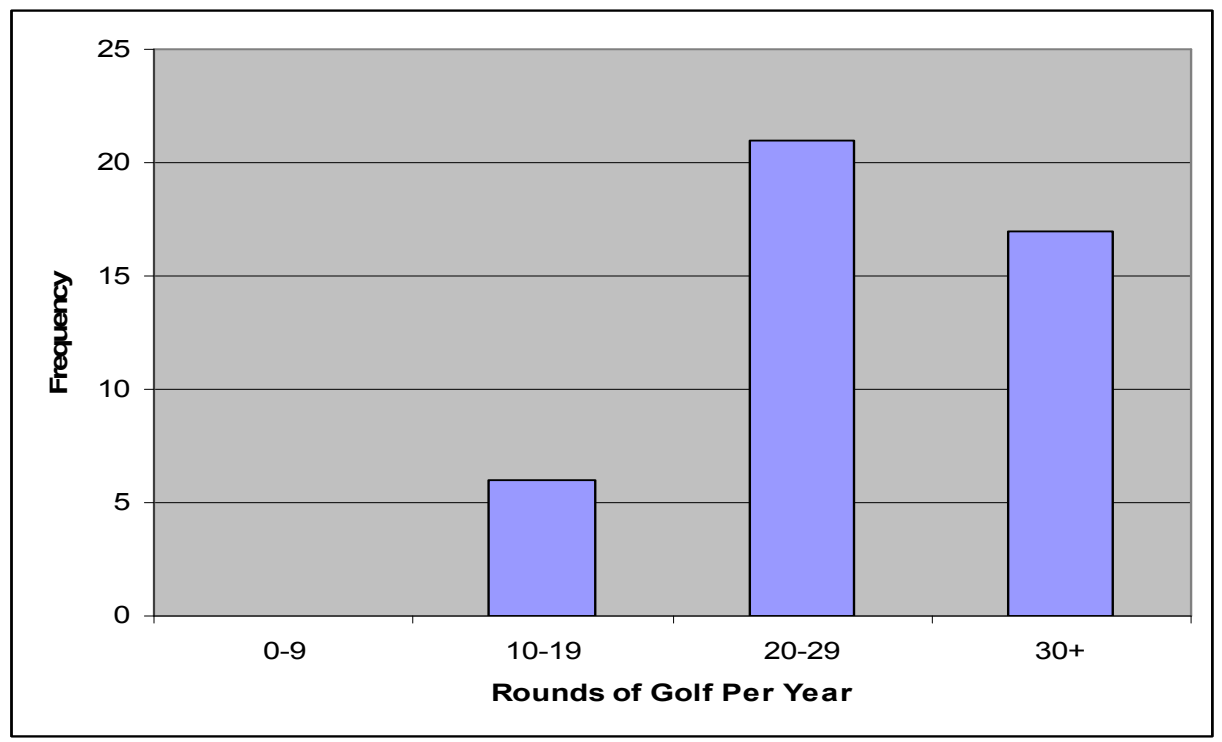


Most golf tourists are also members of golf clubs overseas, with the questionnaire results showing 37 out of the 44 respondents (84\%) being affiliated to a club. Of those who have a golf handicap, the average was 19. This shows that the typical golfer who visits New Zealand is a member of a golf club, players more than 20 rounds each year and is competent at playing the game.

\subsection{Summary}

International golf tourism is viewed as an important source of revenue by New Zealand's top golf courses, contributing up to $50 \%$ of total green players. As with overseas studies, international visitors tend to be older, male and wealthier than the average tourist and stay at higher end accommodation (4 and 5 star). However, these visits tend to be much longer than in other countries, with the average golf visitor on a tour staying for a duration of two weeks. One difference that arises however is that visitors tend to visit New Zealand for more than just golf. Sightseeing opportunities are a significant pull factor in getting international golfers to choose New Zealand as their golfing destination.

While in the country, visitors predominantly play golf at a selection of New Zealand's four core golfing areas (Auckland, Taupo, Christchurch and Queenstown) and in particular the majority only visit during the summer months when the weather is warmer and more settled. While New Zealand's distance from origin countries was seen as a barrier stopping people contemplating a return visit, tourists left with a positive view of their golfing experience. 


\section{Chapter 7 \\ Golf and the Recession in New Zealand}

Overseas studies into the effects of recessions on golf give no conclusive answer to the question of whether golf is immune to its effects. Overall, evidence tends to suggest that while the recession has some effect on the golf and golf tourism industry, this effect is relatively small. For this section, golf tour operators and golf courses were asked questions on the effect that the recession in New Zealand is having on them.

Firstly, a recession is generally defined as two consecutive quarters of falling GDP (or similarly where GDP growth is negative for two or more quarters) (Kuttner and Posen, 2001). Officially, this has recently occurred in New Zealand with GDP falling by $0.3 \%$ in the March 2008 quarter, and by $0.2 \%$ in the June quarter and is the first recession in New Zealand since the 1997-1998 'Asian Financial Crisis' (NZ Herald, 2009). Following five quarters on contraction, GDP growth rose for the first time in the June 2009 quarter, albeit by only 0.1\%. Annual GDP growth from 2003 can be seen in the graph below, clearly showing GDP below its normal level since 2008.

Figure 34: GDP growth rate in New Zealand since 2003

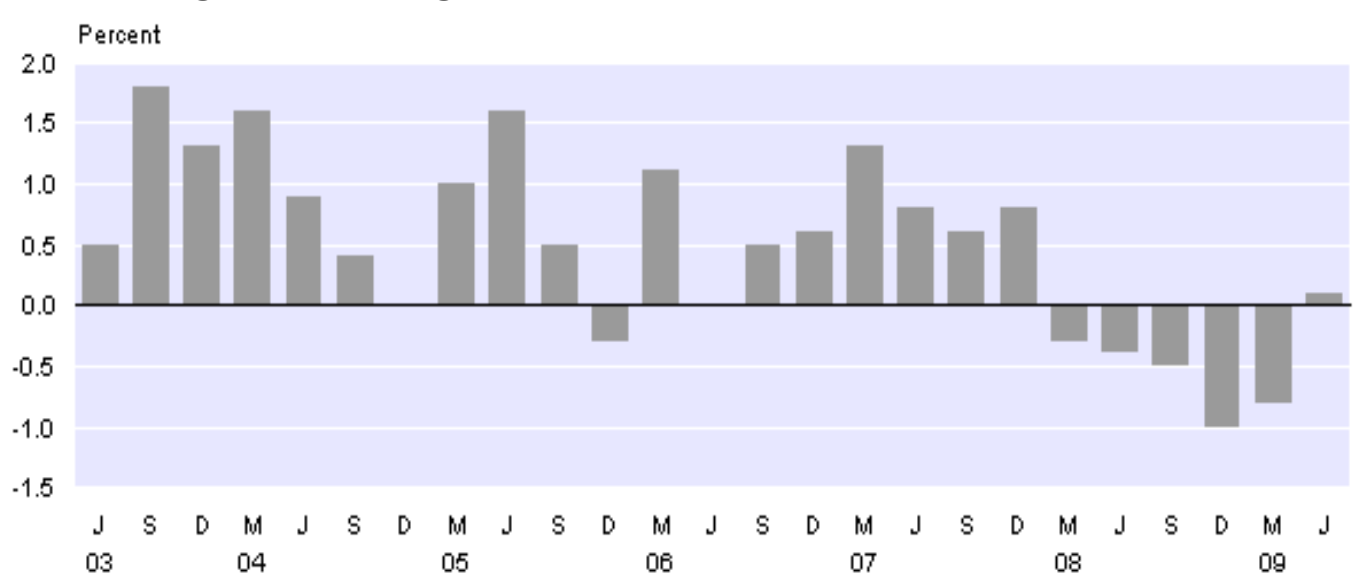

[Source: Statistics New Zealand, 2009b] 
However, what is probably more important for international golf tourism is the effect of the recession in the golf tourist's country of origin. In the US, the effect of the recession was more severe with GDP falling by $6.4 \%$ in the first quarter of 2009 , and $5.5 \%$ in the previous quarter (BEA, 2009).

I do think that the recession has affected us. We have had a few enquires, especially those from the US, who have liked the look of our tours, however they have told us that given the current economic climate they are unable to travel now but may wish to sometime in the future (Rauru Walker, tour operator).

My numbers for the past year have remained relatively constant, although there has been a few less people coming from the US in recent times. Luckily this has been made up with an increase in the number of Australians (anon, tour operator).

The tourism market in New Zealand has been helped by the record number of Australians visiting. This year a record number of Australians have crossed the Tasman and the golf industry seems to be reaping some of its rewards. Since opening in the late 1990's, Terrace Downs had their best ever August in 2009, with high occupancy rates and golf rounds. While this is likely due to a number of factors (e.g. a good ski season and marketing practices), the number of Australians visiting and playing golf certainly helped their cause.

For most of those interviewed, the recession has not had a large impact on their business and golfers continue to come across the Tasman or from further a field to play the game. For some, 2009 has been their best ever year.

The recession has not affected us and the number of tours we have been organising has been rapidly increasing. For many golf touring, like ski touring, is a way of life, not an expendable activity and is pretty sustainable. People may cut back on some expenses while on holiday but will still take that holiday. We target the annual touring groups and they seem relatively unaffected by this so far, 
still looking to travel every year as they have done in the past (Tim Kershaw, tour operator).

I am about to have my best ever year and predict more then 300 golfers. However the previous two years have been terrible! (anon tour operator).

No, the recession has not affected us at all, and the number of golfers booking through us has been steadily increasing since we began [taking tours] in 2004 (anon tour operator).

To be honest, it [the recession] hasn't really done a thing to us. We are a relatively new course, and many people will play the course as a treat. Our target market is the wealthier people and we align ourselves in that manner. We have had a lot of growth recently on the New Zealand side of things as well as growth from Australia (anon, golf course manager).

However, this is not that case for everyone in the industry and in some instances, the past couple of years have resulted in tougher times for some tour operators and golf courses.

There has been a definite decline in player numbers since the beginning of the recession, however player numbers have been declining anyway in recent years and the recession has just accelerated this. We are down $15 \%$ on green fees in the last 18 months (anon, golf course manager).

Golf numbers have declined in recent times. Our hotel revenue has decreased by approximately $20 \%$ for the past year and this of course affects the number of golfers (anon golf course manager).

Our numbers have been steadily increasing over time, but last summer [2008/2009] our numbers were down by about 10\% (anon tour operator). 
While the impact of the recession on the golf industry in New Zealand has given mixed results, overall I would conclude that the recession has had a "minimal impact" on those interviewed. Of the 18 tour operators and golf courses asked this question, each was grouped into one of three categories based on the degree to which the recession was effecting them (a large effect on business, some effect and no effect). A majority (10 out of 18) claimed the recession was having no effect on their business, shown in Figure 35 below.

\section{Figure 35: The Effect of the Recession on those Interviewed}

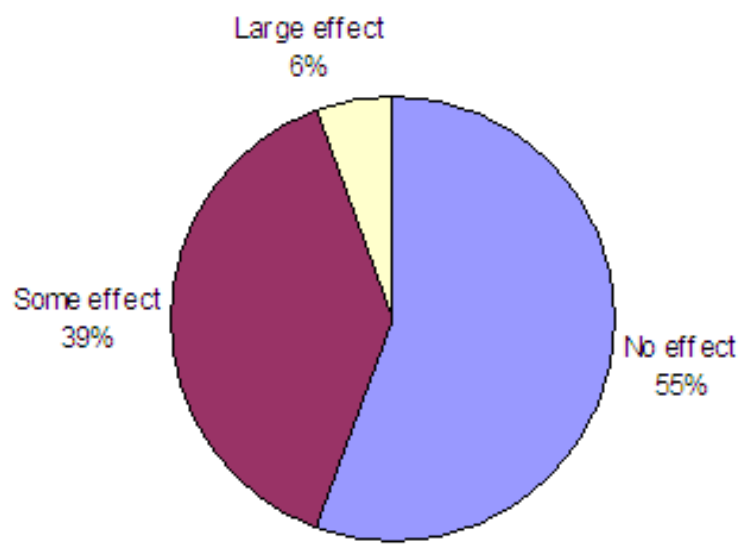

Golf courses were the ones more likely to be affected by the recession. Four out of the six courses interviewed fell under the categories of 'some effect' and 'large effect', while only four out of twelve tour operators were placed there. This may suggest that while international golf tourism is resistant to the effects of the recession, it is a fall in domestic golf tourism that is affecting the industry the most. Other factors could be declining membership numbers, increased competition or an increase in the cost of playing golf.

As part of the question on the impacts of the recession, all those interviewed were also asked about their expectations of the future. The overwhelming consensus here is that nearly all have positive expectations. 
My forward bookings suggest that we are over the worst and with future events such as the Rugby World Cup, I predict a bright future for golf tourism in New Zealand (anon golf tour operator)

Our numbers are down for this year, but I expect it to return to normal figures in 2010 and 2011 (anon golf tour operator).

The golf market is struggling at the moment, but I do not expect player numbers to decline any more. I would expect things to stay similar or constant over the next few years (anon golf course manager).

Our numbers have been down over the past couple of years, but the feedback and enquiries I have been getting seem to suggest that things are improving. I think that once people stop hearing about the recession in the news and the media, everything will start getting back to normal (anon golf tour operator).

Of all those who said the recession was having an impact on them, all were positive about the future of golf tourism in New Zealand. No one interviewed expected numbers to drop in the future. This same question was asked in a study of golf tour operators in the EMA region in 2008 and $90 \%$ of respondents expected steady or spectacular growth in the future. Only $1 \%$ expected there to be a steady decrease in player numbers. 


\section{Figure 36: Future Expectations of Golf Tour Operators in the EMA region}

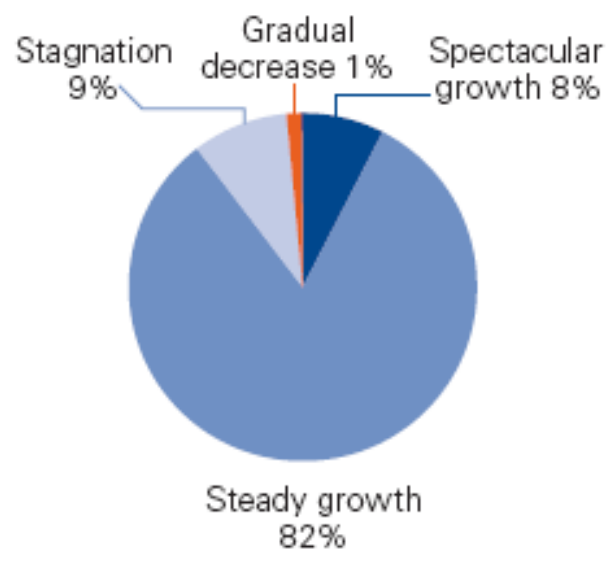

[Source: KPMG, 2008b]

As noted by the study this research was conducted prior to the current recession. However, it still shows that the expectations of those involved in the industry worldwide remain high. The golf tourism industry both in New Zealand and worldwide is seen as being a stable industry in which there remains plenty of room for future growth.

\subsection{Summary}

The effects of the recession on the golf industry in New Zealand follow a similar pattern to what is occurring overseas. While the impacts of the recession can not be completely discounted, its effect on the golf industry does not seem to be as large as that of other industries. Golfers have still been travelling to New Zealand and the numbers taking tours seems to have remained constant (or even increased) over the past few years. The decrease in player numbers and revenue at golf courses throughout the country can not be directly linked to a drop in international visitors as there are a number of other factors contributing to this (such as a drop in domestic tourism). From the interviews it was not possible to isolate the impact of each factor.

Therefore, it can be concluded that the recession has had a limited impact on those interviewed. The consensus that golf is "immune" to the effects of a recession is not entirely true, however my results seem consistent with those found by Lynch (2008). International golf tourism in New Zealand is resilient to the effects of the recession. 


\section{Chapter 8}

\section{Discussion}

In this chapter the information obtained in the results section of the thesis will be discussed and evaluated. Drawing on all previous chapters, this section will predominately look at the mains barriers surrounding the growth of international golf tourism in New Zealand, and what can be done to help overcome these barriers, allowing golf tourism to reach its full potential.

\subsection{The Issues}

Although only a small country, New Zealand has a high concentration of golf courses and golf in this country remains the most participated sport by domestic residents. Over the past decade, a large number of new resort style courses have been invested in with many ranked highly by world standards. Because of this, New Zealand has become a more attractive destination for golf tourists and currently an estimated 65,000 people international visitors play golf while in the country.

However, of the 65,000 visitors who play golf, it is estimated that less than $20 \%$ of these tourists travel to New Zealand specifically to play golf. Therefore as few as 1015,000 visitors could be counted as Type 3 golf tourists. Given that golfers spend a great deal more per trip then the average tourist, it is important for this country to attract as many international golfers as possible. However, four main barriers have been identified that need to be overcome in order for this to occur.

1) New Zealand's geographical isolation

2) The spatial variance of golf courses throughout New Zealand

3) Competition

4) Lack of marketing, especially to key markets 
Each of these will now be discussed in more detail below. It is important to note that each barrier is not an isolated problem and are all interlinked in a number of ways, as shown in Figure 37 below.

Figure 37: A summary of the issues surrounding International Golf Tourism in New Zealand and how they are related

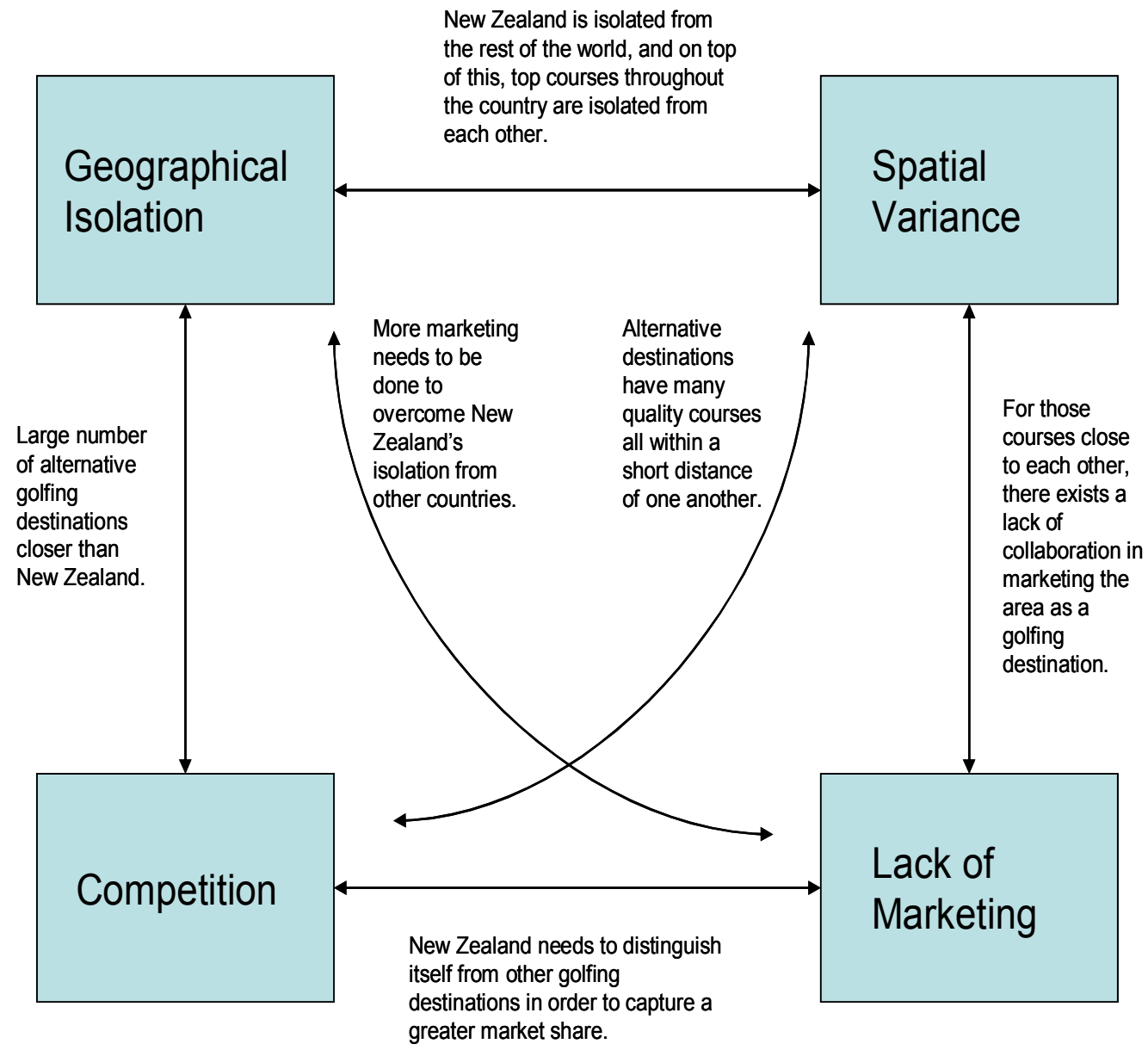

\subsection{Geographical Isolation}

Unlike most countries in Europe, New Zealand is an island surrounded by the Tasman Sea and the Pacific Ocean and shares no borders with any other country. New Zealand's closest neighbour is Australia, lying 2,250km to the west (NZ Territory, 2009). Flight times to the east coast of Australia are approximately 3.5 hours, while it takes a minimum of 12 hours to fly to the United States and up to 24 hours to reach 
Europe. In comparison, from central Europe you can fly to over 50 countries in less than two hours.

As seen from the golfer's questionnaire, the distance travelled was commonly noted as a negative aspect of a golfers visit to New Zealand, especially by those from the United States, Canada and the UK. Of course, this is one issue that can in no way be resolved unless flight times dramatically decrease. The best way to try and overcome this is to change the perceptions of potential visitors. While New Zealand is isolated, it remains only a 12 hour flight on a direct flight from some parts of the US; this does not seem to be realised by many people with the belief that New Zealand is much further away and more difficult to get to.

\subsection{Spatial Variance}

New Zealand has more than 400 golf courses, yet only a small percentage of these are frequently visited by international visitors. Those who travel all this way to specifically play golf have come here to play at New Zealand's top ranked courses. While tour operators will on occasions take their clients to the smaller, more rural course, their tours mostly revolved around playing at the resort style courses.

However, while New Zealand does have many areas with a high concentration of courses all with in a short drive of each other, the resort courses are spread all throughout New Zealand, from Kauri Cliffs north of Auckland to Millbrook and Jacks Point in Queenstown. To play at all of these courses either involves many hours of driving each day or else a number of internal flights. From the golfer's questionnaire this was another common negative aspect of a golfer's visit to New Zealand.

Even through New Zealand is a relatively small country, consistently travelling around the country does not result in the relaxing trip that visitors are looking for. Unlike origin countries, New Zealand does not have the transport infrastructure to allow for high speed travel (apart from flying). There are no motorways travelling the length of the country and coupled with New Zealand's hilly environment, driving times are slow. On top of this, New Zealand does not have a high speed train 
network that is seen in many European countries where trains travel in excess of 300 $\mathrm{km}$ per hour. It takes more than 10 hours to travel by train between Auckland and Wellington. In comparison, Barcelona and Madrid are a similar distance apart however travel time is only three hours.

It therefore becomes difficult for international golfers to play at all of New Zealand's top courses. While those who stayed for a longer period of time (more than two weeks) tended to visit a majority of the courses, those staying for a shorter period of time would only visit a select few (usually two out of the four identified core golfing areas). However, the general consensus from this research is that visitors did wish to visit all areas and that travel time was the main barrier for not achieving this. Given the large distances travelled to visit New Zealand in the first place, return visits for golf are expected to be minimal except for possibly those from Australia.

As with the previous barrier, there is no quick fix solution to this problem. The only solutions for this are to:

a) Improve New Zealand's roading and transport infrastructure: Given many tours are organised as self drive tours, reducing the time to travel between destinations would allow more courses to be played at. It could also help to entice golfers to extend their stay for a longer period of time, thus increasing their expenditure. However, in reality this is unlikely to eventuate, at least not in the short-term. The funding for transport infrastructure in New Zealand is not high, and it is unlikely to rival the systems in place in the UK, US and Europe. While some benefits might arise from this in terms of golf tourism, it is not likely to make a large difference. Travel times were as issue for those already here, but may not have such a large impact for tourists choosing to visit in the first place.

b) The creation of new golf courses in the vicinity of older ones: Many of the courses built in New Zealand in the past decade have been built in relative isolation. While Kinloch has been built in close proximity to Wairakei, and Jacks Point is close to Millbrook, there still exists no singularly large golfing area in New Zealand. For instance in Queensland, there are numerous high quality resort style courses all within a short 30 minute drive of one another, as shown in Figure 38 below. 
Figure 38: High Density Golfing Areas on the Sunshine Coast, Australia

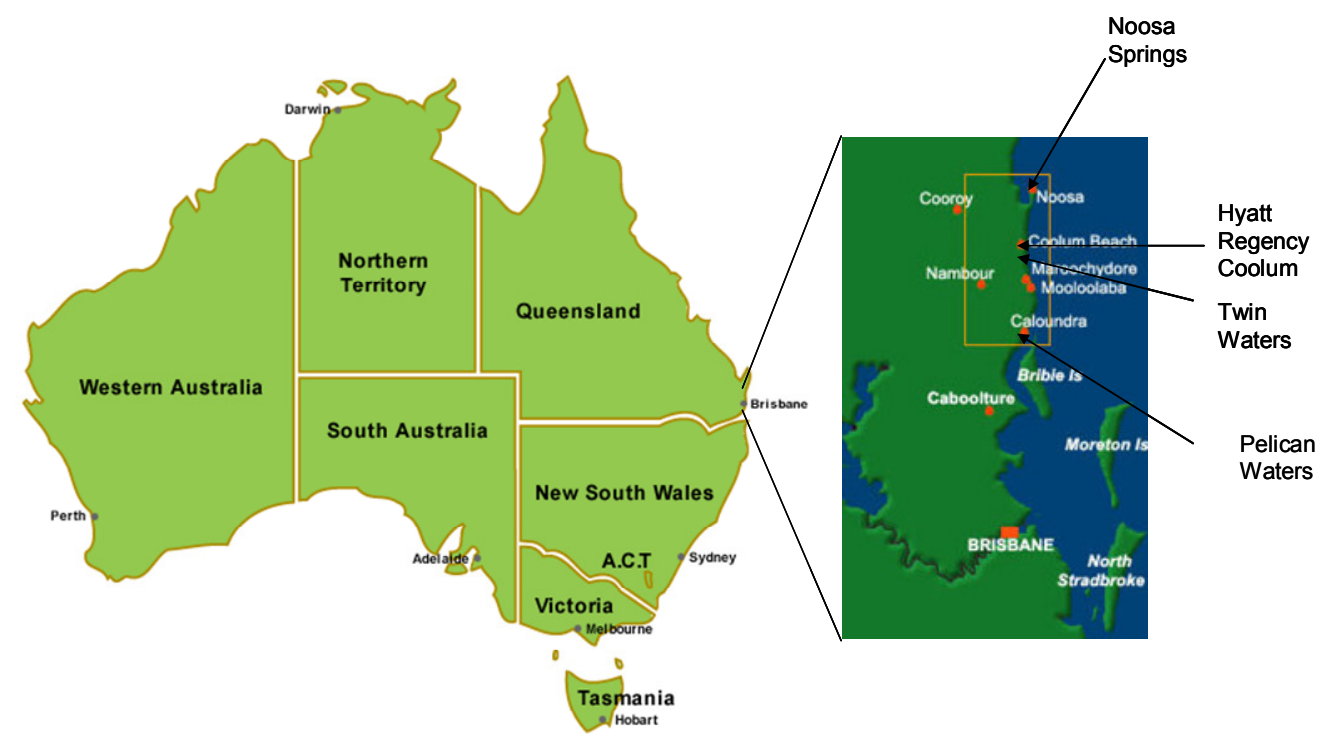

[Source: Golf Desk, 2009]

All of these courses are highly ranked in Australian golf and each year the Hyatt Regency Coolum holds the Australian PGA golf tournament in December. A similar cluster of golf courses can be found in many other parts of Australia, such as the Gold Coast, Melbourne and Sydney areas, Scotland and Europe (especially Spain and Portugal). In order for New Zealand to be more competitive in the international golf tourism industry, these high intensive golfing areas need to be created. Auckland and Queenstown are the only two areas in New Zealand with a number of quality courses close by, however in comparison to other international destinations, the number of courses is not high. New Zealand's top two courses (Cape Kidnappers and Kauri Cliffs) are isolated and are off New Zealand's 'golf trail'.

One solution to this is for all new courses to be built near other resort style courses. Currently, New Zealand as a whole is viewed of as an attractive golfing destination however, it would be beneficial if certain areas within the country could be large golfing destination in themselves (meaning internal travel is limited). The creation of new courses within the four existing core golfing areas of New Zealand could help alleviate this problem. Another solution is to market golf in New Zealand differently. While only a select few resort courses are found near one another, there also exist a 
large number of quality golf courses in these areas which are not promoted to international visitors. This will be discussed in more detail in the 'marketing' section of this discussion.

\subsection{Competition}

There are two types of competition that golf courses in New Zealand face. The first is internal competition, while the second is external competition. Internal competition is the competition between golf courses within New Zealand. These courses are trying to attract as many visitors as possible (both domestic and international) in order to increase their revenue. While this kind of competition may be important for domestic players, this is not such a big issue when it comes to international golf tourists.

Those who are travelling to New Zealand to specifically play golf have come to play at as many golf courses as they possibly can. If two courses are close by, internationals will typically play at both courses rather than just the one. In terms of attracting international visitors, it is therefore important that both course collaborate and work together to promote the area as a golfing destination instead of individually. The largest barrier to the growth of international golf tourism in New Zealand is instead from external competition; alternative golfing destinations in other countries.

As mentioned before, countries such as Spain, Scotland, Portugal and Australia all have a number of high quality courses, often all within a small distance of each other. On top of this, countries such as Thailand, Dubai, Mexico and many others are taking advantage of the increase in the demand for golf worldwide. New Zealand is only one of a large number of options available for golf tourists, making it difficult to gain a large sector of the market, especially given New Zealand's remoteness from the rest of the world.

One of the top pull factors for New Zealand tourism is the country's scenic beauty. However, the literature has shown sightseeing to be the least important factor when choosing a golfing destination. Climate and the quality of golf courses are deemed to be the two most important factors. While New Zealand has a relatively temperate climate and golf can be played 12 months of the year, it is not as warm and sunny as 
Spain, Portugal, Dubai and Australia. On the other hand, the quality of courses in New Zealand is considered to be of a high standard and this is shown in the two awards won by New Zealand for golf in 2001 and 2009 (Best Undiscovered Golf Destination 2002 and Golf Destination of the Year for Australasia and Asia, 2009).

In order for New Zealand to gain a greater share of the international golf market, it needs to set itself apart from other destinations. While sightseeing is not a high priority in KPMG's golf report, it is still an important pull factor in attracting golf tourists to New Zealand. In that report, golf travel in the EMA region averaged between four and seven days. The short duration of trips is due to the close geographical proximity of countries in the region. It means that golfers travel a minimal distance and play a high number of rounds in a short space of time. In comparison given New Zealand's isolation, the duration of stay is much longer in this country with the average golfer staying for at least two weeks.

While golfers in the EMA region played golf on almost every day, golf days in New Zealand are limited to about $60-70 \%$ of their total stay. Sightseeing and other activities will therefore play a more important role during non-golfing days and this was seen with many tour operators organising activities outside of golf (e.g. scenic flights, boat rides and other scenic tours). In the golfer's questionnaire, New Zealand's scenery was often the reason for a golf tourist to choose to visit. The two other main reasons given were the quality of New Zealand's golf courses and the low cost of playing golf. Therefore New Zealand has to use this in order to differentiate itself from other golfing destinations.

\subsection{Lack of Marketing}

New Zealand has a large number of high quality golf courses that are accessible to all who want to play. Nearly all courses are open to the public and are affordable to most people. In addition to this most courses are not busy to play at and can withstand a greater number of players each year. However, even with all these positive attributes, international golf tourist numbers have not come anywhere near their full potential. While a number of problems stopping the growth of golf tourism have been mentioned above, one the largest problems for New Zealand is the lack of awareness 
about golf in New Zealand. This is no surprise given the lack of marketing that occurs to promote golf as a reason for visiting.

This research has shown that expenditure on promoting golf in New Zealand is minimal and if New Zealand is to see prolific growth in golf tourism then a great deal more needs to be done in this respect. Unlike many of the other barriers, an increase in marketing expenditure is more easily achievable. One of the main problems here is getting a large number of courses to all put forward money to collectively promote New Zealand golf, reducing the free-rider problem.

There is currently a reluctance for golf courses to work together to reach a common goal and the small number of courses involved in the Golf Tourism Cluster is a testament to this. In most cases even if two or more courses are in the same area, they do not work together to promote their area as a golfing destination. However, it is easy to see why many courses are reluctant to spend large quantities of money on marketing; it is difficult to measure the benefits that arise from spending extra money.

Golf courses in New Zealand hold very little information regarding international visitors. While some were able to give exact percentages and numbers, many were only able to give an estimation on both the total and their country of origin. It would be beneficial for all of New Zealand's top courses to come up with a system whereby the exact number of visitors and their country are taken and entered into a common database. Simple questions could be asked upon arrival such as:

1) Their name

2) Their country of origin

3) How they heard / found out about the course

If all courses were to do this, the information would then be beneficial for marketing purposes. It would help to quantify the exact importance of international golfers as well as show how player numbers change over time. This would go someway to helping individual courses to see if their marketing expenditure is in anyway beneficial to them. 
Instead of each course promoting itself, expenditure on marketing to international visitors is best spent promoting New Zealand as a whole. The best avenue to do this is through the Golf Tourism Cluster. The Cluster has systems, contacts and ideas already in place, however it is on such a small scale that its true benefits are not being realised. For the Cluster to reach its full potential it needs a large increase in funding and this needs to come from two parties; the golf courses themselves and the government.

While getting a number of golf courses together to promote New Zealand is deemed beneficial, from the interviews conducted with golf courses, it is unlikely that any course would be willing to increase marketing expenditure by a great deal. Therefore, to increase the effectiveness of the Golf Tourism Cluster, a large proportion of funding is required from the government.

With an increase in funding, the Golf Tourism Cluster would be able to expand its marketing techniques (e.g. into television, newspaper and magazines) and reach a far greater audience. The New Zealand government is currently spending an estimated \$50 million on a cycleway spanning the length of the country to attract more international cyclists. Cyclists make up approximately $2 \%$ of total international tourists and spend 1.6 times more than the average tourist (Parker, 2009). This is similar to golf tourists who make up $3 \%$ of total tourist numbers, with spending 1.4 times greater than average. Therefore, a similar argument could be made for the government to spend a similar amount towards promoting golf tourism in New Zealand.

Studies would need to be conducted to determine how much spending would be required in order to achieve the greatest return. This can not be determined from this research and it is quite possible that far less than $\$ 50$ million would be required from the government for the Cluster to maximise its potential. Any expenditure should not solely be seen a cost to the government, but is instead an investment that will reap returns for the New Zealand economy. Such returns include increased tourist expenditure and new job opportunities (which in return increases the government's tax revenue). This investment may also not need to be continuously ongoing; word of mouth was one of the most important ways tour operators gained their clients. By 
increasing the awareness of New Zealand golf now, it is hoped that awareness of New Zealand and its reputation as a golfing destination would improve in this way. However, whatever the value of the investment should be and how long it should continue for, a large proportion of money is best spent on targeting the two largest markets; Australia and the US. Given that the recession seems to be having a minimal impact on golf tourism in New Zealand, targeting golf tourists could be one way of making up the shortfall in the total number of tourists during this time.

Australia has contributed over one million tourists over the past year and accounts for more than a third of the total number of tourists. Similarly, they account for the most golf tourists to New Zealand (between 40 and 50\%) but, there still exists a large potential to increase this. Like New Zealand, golf is a popular sport in Australia who are placed $3^{\text {rd }}$ in the number of golf courses per head of population. Given Australia's close proximity to New Zealand and the large number of potential golfers, it is the most important market to build on.

The next most important market is the US. While only making up 9\% of all types of golfers, they make up over $25 \%$ of golfers who book through tour operators. They tend to stay for longer periods of time, have higher incomes and spend the most out of any nationality. The US contains half the world's golfers but at present, only a few thousand travel to New Zealand to play golf each year. Therefore the potential for steady growth in the number of golf visitors from the US is high. The main way of doing this is by increasing the awareness of New Zealand as a potential golf destination.

One other marketing option that could be used by the government, Golf Tourism Cluster or those in the industry is to market the New Zealand golfing experience differently. Currently marketing is predominantly targeting international visitors to play at the top resort courses throughout the country. However, to play at all of these is not possible on the average two week tour.

As previously mentioned, New Zealand does have a large number 'cluster' golfing areas. For instance, Auckland has more than 40 golf courses to choose from, yet only one of these (Gulf Harbour) is in the brochure provided by the Golf Tourism Cluster. 
There are enough golf courses for an international visitor to play during a two week stay in Auckland alone (and having done so the author can attest to this). The same can be said for many other regions in New Zealand such as Taupo, Christchurch and Queenstown. While each region has one or two well known or famous courses, others receive little attention. Instead of solely marketing New Zealand golf as a whole, the focus could also be shifted to marketing key areas with a high number of golf courses. Responsibility to do this could be put on those areas that would benefit (e.g. local government in these cluster areas).

While the primary focus of this thesis was on visitors taking golf tours, all types of golf tourists are important to New Zealand and the golf industry. The resort courses that these tours visit tend to be open to the public most days of the year. However, most other courses in New Zealand are member owned clubs and can be slightly more difficult to get onto. Most clubs have men's and ladies days during the week as well as other veteran and club events throughout the year. Therefore in some instances tourists may not have access to a course when they want to. Regional brochures (at information centres, hotels and online) regarding all nearby golf courses as well as their opening times may be required to help raise the level of awareness of golf in the area.

A search for golf on regional tourism websites (e.g. Tourism Auckland, Tourism Wellington etc) took a number of steps and in many cases information on golf in the area was not readily available. On top of the Golf Tourism Cluster promoting New Zealand as a whole, it would be beneficial for each region to promote their own courses. While Type 3 golf tourists on tours tend to play at the resort courses, many other independent golfers as well as Type 1 and Type 2 tourists will still play at the other 400 courses throughout New Zealand. If marketing can be done at the regional as well as the national level, this will help to cover all types of tourists.

\subsection{Comparisons and Definitions}

Lastly, this thesis has attempted to make a number of comparisons between golf tourism in New Zealand and that from other parts of the world. While it has been possible in some instances, methodology differences have made this difficult in many 
circumstances as there is no consistent definition of golf tourism. Many studies use a very loose definition whereby if a tourist plays one game of golf while on a holiday then they are counted as a golf tourist (Type 1 golf tourist). However, in some cases a more narrow definition is used whereby golf has to be the main motivating factor for a holiday to be counted (Type 3 golf tourist).

This thesis has recognised another type of golf tourist; where golf was a pull factor for someone to travel, but not necessarily the main factor (Type 2). The Golf Tourist Continuum in Chapter 4 shows all three types. It is the author's view that Type 1 tourists should not formally be included as 'golf tourists'. A person who plays one round of golf on a month long trip sightseeing around New Zealand is a sightseer, not a golf tourist. However, these tourists were included in some part of this thesis (Ministry of Tourism's data, Chapter 5) both out of interest and as a way of comparing New Zealand to overseas studies (especially those in the US).

In the future, it would be beneficial if all studies were able to use a consistent measure. It is the author's view that motivation is the important factor in determining whether a visitor should be included as a golf tourist. If the golf courses in New Zealand acted as a pull factor in attracting a tourist here, then they can be formally recognised as a golf tourist. Therefore they should only be included as such if they are a Type 2 or Type 3 tourist. This is a wider definition than some studies, but a narrower definition than others and hence acts as a good middle ground to work from. 


\section{Chapter 9}

\section{Conclusion}

International research has shown golf tourism to be a multi billion dollar industry. In the US alone, golf travel is estimated to add $\$ 18$ billion to their economy. In the past twenty years, countries have acknowledged the financial benefits of golf tourism and this has seen an explosion in the number of golf courses in many parts of the world. Countries such as Spain, Portugal and Scotland and Australia are noted golfing destinations and in recent years, Dubai, Thailand and many other countries are emerging as golf tourist destinations. New Zealand is one of these countries, with a number of new high quality golf courses built in the past decade aimed to attract a significant number of international golfers.

This research has shown that thousands of international visitors come to New Zealand each year to participate in the game of golf, spending hundreds of millions while travelling the country. Golf tourists who visit New Zealand will tend to spend most of their time at four core golfing areas throughout the country (Auckland, Taupo, Christchurch and Queenstown). Golfers, especially those who travel to specifically play the game, tend to be older, wealthier and spend significantly more than the average tourist.

While this thesis was mainly concerned with those taking golf tours (Type 3 golf tourists), the results showed that the average age of visitors was about 55-60 years old. The average duration for each tour was two weeks, although averages varied depending on the visitor's country of origin. As expected, the greater the distance travelled, the longer the visitor stayed and the more golf courses played. Golf tourism in New Zealand is also very seasonal, with tourists generally only visiting during the warmer months between December and March.

Currently only about $3 \%$ of international visitors partake in at least one game of golf while in the country. However, given their greater spending and the capacity for golf 
courses throughout the country to host many more visitors, it is an important market segment to grow. Data from the Ministry of Tourism has shown that the direct economic gains from international visitors who play golf in New Zealand to be an average of \$243 million each year. Including all indirect and induced effects these gains could be as high as $\$ 493.29$ million.

While the construction of a number of new golf courses and winning two international awards has likely increased the limelight on New Zealand as a golfing destination, international visitor numbers are not reaching their full potential, and any growth over the past decade has been at a low rate. However, one benefit to the industry has been the minimal impact of the recession over the past two years with most in the golf tourism industry finding total tourist numbers to be just as high as in previous years.

It would therefore be beneficial for the New Zealand tourism industry to be proactive in attracting more international golf tourists. However, in order to achieve this New Zealand needs to overcome a number of barriers that are limiting its growth. If New Zealand can create high density golfing areas within the country and then effectively market the country to the most important markets (Australia and the US), golf tourism in this country will have a better chance of seeing faster growth. This is beneficial not only to the golf industry, but to all surrounding areas where golf is played and even the New Zealand economy as a whole. 


\subsection{Areas for Future Research}

Prior to this thesis, there has been no other known research conducted into the effects of golf tourism to New Zealand. In addition to this, there has been very little research into any other aspects relating to golf (e.g. the environmental impact of golf). This means many areas exist for future research on aspects related to this topic and these are listed below.

\section{1) Expanding the Golfer's Questionnaire}

During this thesis, the golfer's questionnaire was passed on the golf tourists through a select few golf tour operators. This, coupled with the fact that this questionnaire was sent off during a quiet period for golf tourism meant that only 44 were returned. While this gave a good insight into the behaviour and satisfaction of international golf tourists, it would be advantageous to expand this and get a greater number of respondents. This would allow for a more rigorous statistical analysis.

On top of this, if the questionnaire could be answered at the golf courses themselves, it would be possible to gain an understanding into all golf tourists and not just those on golf tours. This could help answer questions such as the percentage of visitors who use tour operators versus FIT and the differences between Type 1, Type 2 and Type 3 golf tourists.

\section{2) Analysing a greater range of golf courses}

This thesis only researched a select number of golf courses, and all of these were resort style courses. However, in New Zealand most golf courses are member owned club courses (not for profit) and these courses were not interviewed during this research. While these courses will not likely make up a large proportion of Type 3 golf tourists who visit New Zealand, they can not be completely discounted. Analysing the green fee records at a large number of golf courses throughout New Zealand would help to shed light on those international visitors who decide to play at the smaller and more rural courses. 


\section{3) Domestic Golf Tourism}

While international golf tourism is important for the golf industry in New Zealand, domestic golf tourism is just as, or even more important given New Zealand's isolation and that golf is the number one sport for participation in this country. Having research into both types will give a greater view into the New Zealand golf industry.

\section{4) The Environmental Implications of Golf Tourism}

The most research that has been conducted into golf worldwide has focused on the environmental impacts that golf courses cause. This includes the construction of new courses, where new wildlife and habitat destruction becomes an issue, as well as changes in waterways, runoff and changes in land use (i.e. is the land better utilised as farmland)?

For existing golf courses, research includes the impact that the use of chemicals (such as fertilisers) have on both the health of people and surrounding wildlife, and the large quantities of water needed to irrigate a golf course. While of a concern in other countries, are these environmental impacts of such a concern in New Zealand? If they are of a concern, what are New Zealand golf courses currently doing to minimise environmental impacts?

\section{5) New Zealand's Level of Support for new Golf Courses}

Related to the previous topic, overseas studies have been conducted into how people view the construction of new golf courses. While many previous studies have revolved around scientific methods used to identify possible environmental impacts, only a small level of research has looked at the thoughts of the local community. Is the construction of a new course viewed as a positive (for instance, do locals see it as being a scenic green space), or is it instead viewed as an eyesore on the landscape? Also, if golf courses are commonly viewed of as being a negative addition to the landscape, what are steps that could be taken in order to overcome this? 


\section{6) Behaviour and Motivational Traits of Inbound Golf Tourists}

While thousands of inbound golf tourists travel to New Zealand each year, very little is known about their reasons for travelling in the first place. While this thesis has briefly touched on this issue, it would be beneficial to find out more about the psychology of the golf tourist. From this, a comparison could be done regarding the differences in the behaviour and motivations of tourists from New Zealand's main markets (e.g. Australia, US, UK, Canada and Asia). This would help to utilise the appropriate marketing mix for each market when differences arise.

\section{7) Economic Impact Report}

As shown in the literature review section of this thesis (Chapter 4), a number of countries and US states have released economic impact reports for the golf industry. While golf tourism is a part of this, it also includes the economic benefits created by golf equipment sales, golf course's capital investment, real estate and all other golf related spending activities. An estimation for the economic impact of the entire golf industry could also be done for New Zealand. 


\section{References}

ABC News. (2009) Global Financial Crisis. [Online] Available from:

http://www.abc.net.au/news/events/financialcrisis/charts/gdpgrowth.htm [Accessed 15/10/09]

Aclant. (2009) Recession slows but doesn’t stop local golf industry - Trading Markets (Press Release). [Online] Available from: http://aclant.com/2009/05/09/recession-slows-but-doesnt-stop-local-golfindustry-trading-markets-press-release [Accessed 15/06/2009]

Air NZ. (2010) Travel Information. [Online] Available from: http://www.airnewzealand.co.nz/before-you-fly/baggage [Accessed 01/02/10]

BBC. (2009) Average Conditions. [Online] Available from: http://www.bbc.co.uk/weather/world/city_guides [Accessed 02/10/2009]

BEA. (2009) Quarter-to-Quarter growth in Real GDP. [Online] Available from: http://www.bea.gov/newsreleases/national/gdp/gdp_glance.htm [Accessed $15 / 10 / 09]$

Best of Golf New Zealand. (2009) About Us. [Online] Available from: http://www.bestofgolfnewzealand.com/About+Us.html [Accessed 15/04/2009]

Bond, C. (2007) The home of golf tourism. Event, 43-44

Botha, C, Crompton J \& Kim, S. (1999) Developing a Revised Competitive Position for Sun/Lost City, South Africa. Journal of Travel Research, 37(4), 341-352

Briassoullis, H. (2007) Golf-centered Development in Coastal Mediterranean Europe: A Soft Sustainability Test. Journal of Sustainable Tourism, 15(5), 441-462

Burns, G. Interviewed by: Gazley, C. ( $7^{\text {th }}$ October 2009) 
CIA World Factbook. (2009) Japan - Population. [Online] Available from: https://www.cia.gov/library/publications/the-world-factbook/print/ja.html [Accessed 12/04/09]

CMMA (2008) The Recession's Effect on Golf Business. [Online] Available from: http://cmaa.org/template.aspx?id=24034 [Accessed 15/05/09]

Cooter, R, Papendick, D, \& Washington, N. (2003) An Economic Impact Study of the Golf Industry on the State of Georgia. Office for Sports Business Research, Georgia State University, Atlanta

Cox, C. (2001) "Pesticides on Golf Courses: Mixing Toxins with Play?. Journal of Pesticide Reform, 11(3), 1-4

Decrop, A. (1999) Triangulation in qualitative tourism research. Tourism Management, 20, 157-161

Delpy, L. (1997) An overview of sport tourism: Building towards a dimensional framework. Department of Tourism and Hospitality Management, The George Washington University

Department of Environmental Protection. (2009) Florida Drought Conditions Frequently asked Questions. [Online] Available from: http://www.dep.state.fl.us/Drought/faq.htm [Accessed 01/04/09]

EGA. (2009) European Golf Association: Statistics. [Online] Available from: http://www.ega-golf.ch/050000/050300.asp [Accessed 20/02/09]

Fea, S. (2010) \$20 Million Benefit estimate for NZ Open, Southland Times, $02 / 02 / 2010$

Gange, A, Lindsay D \& Schofield, J. (2003) The ecology of golf courses. Biologist, 50(2), 63-68 
Gibson, H. \& Pennington-Gray, L. (2005) Insights from Role Theory: Understanding Golf Tourism. European Sport Management Quarterly, 5(4), 443-468

Gnoth, J. (1997) Tourism Motivation and Expectation Formation. Annals of Tourism Research, 24(2), 283-304

Golf 20/20. (2009) Economic Impact Reports. [Online] Available from: http://www.golf2020.com/economicresearch.aspx [Accessed 28/03/2009]

Golfbenchmark. (2009) Our Publications. [Online] Available from: http://www.golfbenchmark.com/index.thtml/en/Reports/ [Accessed 16/03/09]

Golf Channel. (2009) A Brief History of Golf. [Online] Available from: http://www.golfchannelsolutions.com/markets/usa [Accessed 21/10/2009]

Golf Desk. (2009) Sunshine Coast Locations. [Online] Available from: http://www.thegolfdesk.com.au/location-map.php [Accessed 13/10/09]

Golf Digest. (2007) Most Golf Courses Per Head of Population [Online] Available from: http://www.golfdigest.com/magazine/golf-digest [Accessed 27/04/2009]

Golf Tourism Monitor. (GTM). (2010) 2009 National Golf Tourism Monitor. [Online] Available from: http://www.visitscotland.org/pdf/2009_golf_monitor_report.pdf [Accessed 23/02/2010]

Hennessey, S, MacDonald, R and MacEachern, M. (2006) Examining Golfer Characteristics: A Framework for Understanding Visitors to a Destination. In Tourism in Transition, TTRA, Canada Chapter Conference Proceedings, Quebec, Canada

Hinch, T. \& Higham, J. (2001) Sports Tourism: a Framework for Research. International Journal of Tourism Research, 3, 45-58 
Huka Lodge. (2009) Huka Lodge Image. [Online] Available from:

http://www.hukalodge.co.nz [Accessed 19/07/09]

HVCB. (2003) HVCB Tourism Industry Update. [Online] Available from: http://www.hvcb.org/media/documents/TIU2003.11.10.pdf [Accessed 23/03/09]

Japan Golf. (2009) Golf in Japan. [Online] Available from: http://www.golf-injapan.com/visitor.php [Accessed 31/03/09]

Kim, S. \& Lee, C. (2002) Push and Pull Relationships. Annals of Tourism Research, 29(1), 257-260

KPMG. (2008a) The Value of Golf to Europe, Middle East and Africa - A study on the Golf Economy. [Online] Available from: http://www.golfbenchmark.com/index.thtml/en/value [Accessed 16/02/09]

KPMG. (2008b) Golf Travel Insight in EMA 2008. [Online] Available from: http://www.golfbenchmark.com/index.thtml/en/travel/ [Accessed 16/02/09]

Kunihiro, Y. (1990) The Triple Evils of Golf Courses. Japan Quarterly, 37(3), 291297

Lahr, M. Grady, B \& Burch, B. (2007) Economic Impacts of the New Jersey Golf Industry. Prepared for New Jersey Golf Owners Association, October 15, 2007

Litvin, S. (2000) Revisiting the Heavy-User Segment for Vacation Travel Marketing. Journal of Vacation Marketing, 6(4), 346-356

Luxury Golf Tours. (2010) Tour Operator Website. [Online] Available from: http://www.luxurygolftoursnz.com [Accessed 22/02/10] 
Lynch, A. (2009) The Golf Business During Recessions: Analysis and Perspectives. [Online] Available from: http://www.ngf.org/cgi/researchreports.asp. [Accessed 15/05/2009]

Marshall, M. (1996) Sampling for qualitative research. Family Practice, 13(6), 522525

McCabe, S. (2000) Tourism Motivation Process. Annals of Tourism Research, 27(4), $1049-1052$

McIntyre, I. (2007) Edinburgh Surgery and the history of golf. J R Coll Physicians Edinb, 37, 367-371

Ministry of Tourism. (2009) Tourism Databases. [Online] Available from: http://www.tourismresearch.govt.nz/Help--How-to/TourismDatabases/Accessing-the-Tourism-Database [Accessed 03/06/09]

Morley, C. (1992) A Microeconomic Theory of International Tourism Demand. Annals of Tourism Research, 19, 250-267

Nauright, J. \& Wheeler K. (2006) A Global Perspective on the Environmental Impact of Golf. Sport in Society, 9(3), 427-443

Nesbitt, L. \& Woodifield, P. (2009) Golf Recession Strikes Ireland, Scotland as Clubs Shed Workers. [Online] Available from: http://www.bloomberg.com/apps/news?pid=20601102\&sid=a8UdugvgiMGM \&refer=uk [Accessed 27/05/09]

Newsome, D. Moore, S. \& Dowling, R. (2002) Natural Area Tourism: Ecology Impacts and Management. UK: Channel View Publications

Nicholls, S. \& Crompton, J. (2005) Why Do People Choose to Live in Golf Course Communities?. Journal of Park and Recreation Administration, 23(1), 37-52 
Nicholls, S. \& Crompton, J. (2007) The Impact of a Golf Course on Residential Property Values. Journal of Sport Management, 21, 555-570

NZGA. (2009) Golf Statistics. [Online] Available from: http://www.nzga.co.nz/Article.aspx?ID=1224 [Accessed 14/03/09]

NZ Golf Tourism Cluster. (2003) NZ Golf Tourism Cluster: Cluster members Update (Issue 1). [Online] Available from: http://www.jasons.com/listings/10037858/ brochure/pdf/issue1aug03new.pdf [Accessed 12/02/09]

NY Times. (2009) Want to play golf in Japan? Got a Million [Online] Available from: http://www.nytimes.com/1987/09/25/business/want-to-play-golf-in-japan-gota-million.html?pagewanted=all [Accessed 24/08/09]

NZ Herald. (2008) Recession Confirmed - GDP falls. NZ Herald, 26/09/09

NZIER. (2009) Economic Impact of the New Zealand Wine Industry: An NZIER report to New Zealand winegrowers. [Online] Available from: http://www.nzier.org.nz/Site/Publications/NZIER_reports_to_clients.aspx [Accessed, 03/11/09]

O’Leary, Z. (2006) The Essential Guide to Doing Research. London, Cromwell

One Caribbean. (2009) Golf. [Online] Available from: http://www.onecaribbean.org/content/files/Golf.pdf [Accessed 05/02/09]

Parker, T. (2009) Why Key's national bike trail could be paved with gold. NZ Herald, 23/03/09

Perry, A. (2004) Sports Tourism and Climate Variability. Department of Geography, University of Wales Swansea 
PGA Australia. (2006) An independent study into the size of the Australian golf economy. [Online] Available from:

www.pga.org.au/_content/document/00034974-src.pdf [Accessed 05/05/09]

Pitts, B. (1999) Sports tourism and niche markets: Identification and analysis of the growing lesbian and gay sports tourism industry. Journal of Vacation Marketing, 5(1), 31-50

Priestly, G. (2006) Planning implications of golf tourism, Tourism and Hospitality Research, 6(3), 170-178

Qantas. (2010) Checked Baggage Allowance. [Online] Available from: http://www.qantas.com.au/travel/airlines/checked-baggage/global/en [Accessed 01/02/2010]

Randa. (2009)The R\&A St Andrews. [Online] Available from: http://www.randa.org/home/homeOfGolf/home [Accessed 14/04/09]

Readman, M. (2003) Golf Tourism. In S. Hudson (Ed.), Sport and adventure tourism, New York, The Haworth Hospitality Press

Remarkable Golf Tours. (2010) Tour Operator Website. [Online] Available from: http://www.remarkablegolftours.co.nz [Accessed 22/02/2010]

Schumacher, C. \& Spoonley, P. (2008) Estimating economic impacts in New Zealand: Technical issues. New Zealand Geographer, 64, 221-227

Scottish Parliament Information Centre [SPIC]. (2002) Niche Tourism in Scotland: Golf and Business Tourism. [Online] Available from: www.scottish.parliament.uk/business/research/pdf_res_brief/sb02-94.pdf [Accessed 12/02/09]

Sparc. (2009) Sport and Recreation Participation Levels. [Online] Available from: http://www.activenzsurvey.org.nz/Results/2007-08-Active-NZ- 
Survey/Findings-200708-Active-New-Zealand-Survey/Sport-and-Recreation-

Participation-Levels [Accessed 14/04/09]

Sportsbusiness. (2004) The business of sport tourism. [Online] Available from: www.sportsbusiness.com/reports/160251/the-business-of-sport-tourism [Accessed $12 / 02 / 09]$

Statistics New Zealand. (2008) Tourism Satellite Account: 2007. Wellington, Statistics New Zealand.

Statistics New Zealand. (2009) International Passenger Traffic. [Online] Available from: http://www.stats.govt.nz/analytical-reports/tourism-migration2000/tourism-and-migration-part1.htm [Accessed 27/05/09]

Statistics New Zealand. (2009b) National Accounts [Online] Available from: http://www.stats.govt.nz/browse_for_stats/economic_indicators/nationalaccounts/nati onalaccounts_hotpyemar09.aspx [Accessed 15/05/09]

Stynes, D. Sun, Y and Telhelm, D. (2000) Michigan Golf Tourists - Economic Impacts. Department of Park, Recreation and Tourism Resources, Michigan State University

Tourism Australia. (2010) Visitor Arrivals. [Online] Available from: http://www.tourism.australia.com/Research.asp?lang=EN\&sub=0318 [Accessed 04/02/2010]

Tourism Concern. (2003) Golf Campaign. [Online] Available from: www.tourismconcern.org.uk/campaigns/campaignsgolf.htm [Accessed 01/04/09]

Tourism Victoria. (2008) Golf Tourism: Market Profile Year Ending December 2007. [Online] Available from: 
http://www.tourism.vic.gov.au/images/stories/marketsegments/golf-wfs-dec2007.pdf [Accessed 19/03/2009]

UNEP. (2004) Tourism and Biodiversity: Mapping Tourism's Global Footprint. [Online] Available from: http://www.unep.org/PDF/Tourism-andbiodiversity.pdf [Accessed 01/04/09]

Videria, N. Correia, A. Alves, I. Ramires, C. Subtil, R. Martins, V. (2006) Environmental and economic tools to support sustainable golf tourism: The Algarve experience, Portugal. Tourism and Hospitality Research, 6(3), 204217

Visit Scotland. (2009) The official site of Scotland's national tourism organization. [Online] Available from: http://www.visitscotland.com [Accessed 18/04/09]

Weed, M. (2004) Sports tourism research 2000_2003: A systematic review of knowledge and a metaevaluation of method. Paper presented at the Twelfth European Association of Sport Management Congress, Ghent, Belgium, September.

Weed, M. (2005) Sports Tourism Theory and Method - Concepts, Issues and Epistemologies. European Sport Management Quarterly, 5(3), 229-242

Weed, M and Bull, C. (2004) Sports tourism: Participants, policy and providers. Amsterdam, Elsevier

Worldgolf. (2009) Golf datatech completes through study of golf consumer areas. [Online] Available from: http://www.worldgolf.com/newswire/browse/12914Golf-Datatech-completes-thorough-study-of-golf-consumer-areas [Accessed 25/05/09]

World Travel and Tourism Council. (2009) Tourism Impact Data and Forecasts: World - Key Facts at a Glance. [Online] Available from: 
http://www.wttc.org/eng/Tourism_Research/Tourism_Economic_Research [Accessed 03/04/09]

WWF. (2004) Freshwater and Tourism in the Mediterranean. WWF Mediterranean Programme, Rome

Zhang and Marcussen. (2007) "Tourist motivation, market segmentation and marketing strategies" Centre for Regional and Tourism Research, Stenbrudsvej, Denmark. [Online] Avaliable from:

http://www.crt.dk/media/tourism_motivation_and_marketing_strategies_denm ark_jie_zhang_carl_henrik_marcussen_crt_2007.pdf [Accessed 27/04/09] 